San Jose State University

SJSU ScholarWorks

Master's Theses

Master's Theses and Graduate Research

1993

\title{
Estimation of pile frictional capacity in clayey sedimentary deposits in Taipei using CPT data
}

Wie-Kong Jie

San Jose State University

Follow this and additional works at: https://scholarworks.sjsu.edu/etd_theses

\section{Recommended Citation}

Jie, Wie-Kong, "Estimation of pile frictional capacity in clayey sedimentary deposits in Taipei using CPT data" (1993). Master's Theses. 550.

DOI: https://doi.org/10.31979/etd.h4pc-n9nw

https://scholarworks.sjsu.edu/etd_theses/550

This Thesis is brought to you for free and open access by the Master's Theses and Graduate Research at SJSU ScholarWorks. It has been accepted for inclusion in Master's Theses by an authorized administrator of SJSU ScholarWorks. For more information, please contact scholarworks@sjsu.edu. 


\section{INFORMATION TO USERS}

This manuscript has been reproduced from the microfilm master. UMI films the text directly from the original or copy submitted. Thus, some thesis and dissertation copies are in typewriter face, while others may be from any type of computer printer.

The quality of this reproduction is dependent upon the quality of the copy submitted. Broken or indistinct print, colored or poor quality illustrations and photographs, print bleedthrough, substandard margins, and improper alignment can adversely affect reproduction.

In the unlikely event that the author did not send UMI a complete manuscript and there are missing pages, these will be noted. Also, if unauthorized copyright material had to be removed, a note will indicate the deletion.

Oversize materials (e.g., maps, drawings, charts) are reproduced by sectioning the original, beginning at the upper left-hand corner and continuing from left to right in equal sections with small overlaps. Each original is also photographed in one exposure and is included in reduced form at the back of the book.

Photographs included in the original manuscript have been reproduced xerographically in this copy. Higher quality $6^{\prime \prime} \times 9^{\prime \prime}$ black and white photographic prints are available for any photographs or illustrations appearing in this copy for an additional charge. Contact UMI directly to order.

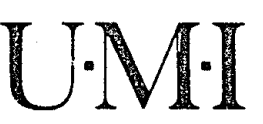



Order Number 1553027

Estimation of pile frictional capacity in clayey sedimentary deposits in Taipei using CPT data

Jie, Wie-Kong, M.S.

San Jose State University, 1993

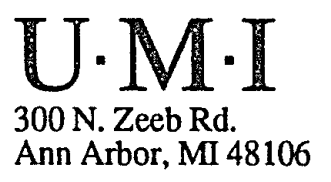





\title{
ESTIMATION OF \\ PILE FRICTIONAL CAPACITY IN CLAYEY SEDIMENTARY \\ DEPOSITS IN TAIPEI USING CPT DATA
}

\author{
A THESIS \\ Presented to \\ The Faculty of the Department of \\ Civil Engineering and Applied Mechanics \\ San Jose State University
}

In Partial Fulfillment

of the Requirements for the Degree

Master of Science

By

Wie-Kong Jie

May 1993 
APPROVED FOR THE DEPARTMENT OF

CIVIL ENGINEERING AND APPLIED MECHANICS
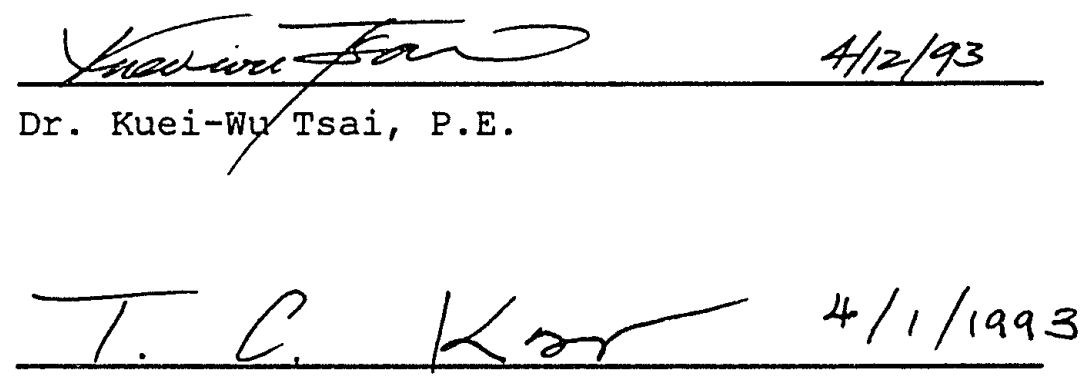

Dr. T. C. Kao, P.E.

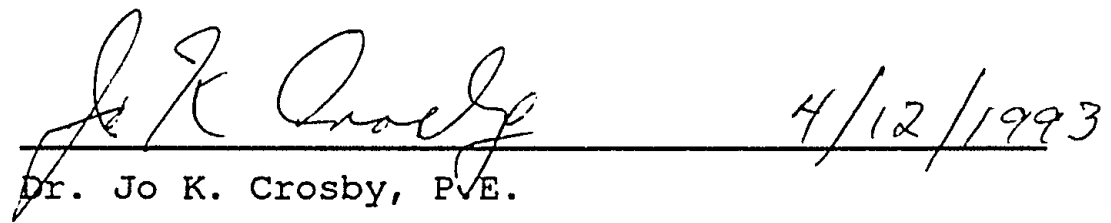

APPROVED FOR THE UNIVERSITY

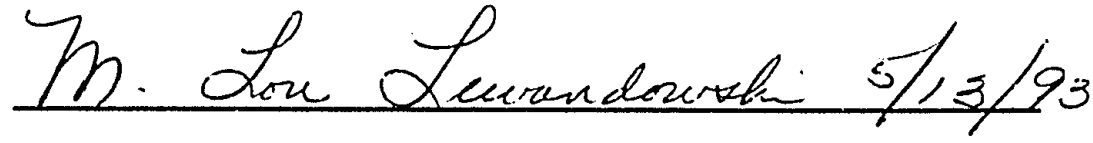




\section{ABSTRACT \\ ESTIMATION OE \\ PIIE FRICTIONAI CAFACITY IN CIAXEY SEDIMENTARY DEPOSITS IN TAIPEI USING CPT DATA \\ by Wie-kong Jie}

This thesis demonstrates that the present state-of-the-art methods for utilizing Cone Penetration Test data for pile frictional capacity prediction in cohesive soils agree reasonably well the observed maximum capacity of the tested piles when using methods suggested by Tumay and Fakhroo (1981). However, the method suggested by Schmertmann (1978) tends to underestimate the load carrying ability of the piles.

The observed maximum frictional capacity is defined from the load versus butt settlement curve of pile test results. The difference between these two computed frictional capacities is due to the significant difference of their relevant adhesion factors for cone friction lower than 0.36 $\mathrm{kg} / \mathrm{cm}^{2}$, where the adhesion factor from Tumay et.al. is higher than from schmertmann. 
AUTHOR'S NOTE

The six instrumented test piles and eighteen case studies presented in Chapters 3 and 4, respectively, are from geotechnical projects in which the author participated as engineer for Moh and Associates, Inc., (MAA) of Taipei, Taiwan. The information and many of the figures are from project reports and other documentation; because this information is proprietary, the instrumented data and cases are identified by letter and number designations only, sources are referenced as MAA project reports, and the actual reports are not listed in Appendix A. References. Appreciation is extended to MAA and to the individual contributors who provided access to these materials. 


\section{ACKNOWLEDGMENTS}

The author is particularly indebted to his advisor, professor Kuei-Wu Tsai for his understanding, patience, guidance, and inspiration. Great appreciation is extended to Professors Jo Crosby and T.C. Kao for serving as members of the thesis committee as well as for giving useful suggestions and advice.

Grateful thanks are extended to the author's colleagues for their interest and support. I. S. Iin and I. S. Wang did the drafting of all the figures. Research assistance was provided by Louis Shu and C.c. Huang, and word processing help was given by Catherine Iiao.

Finally, deepest personal appreciation is extended to the author's wife, Kitty, for her love, understanding and encouragement. 


\section{TABLE OF CONTENTS}

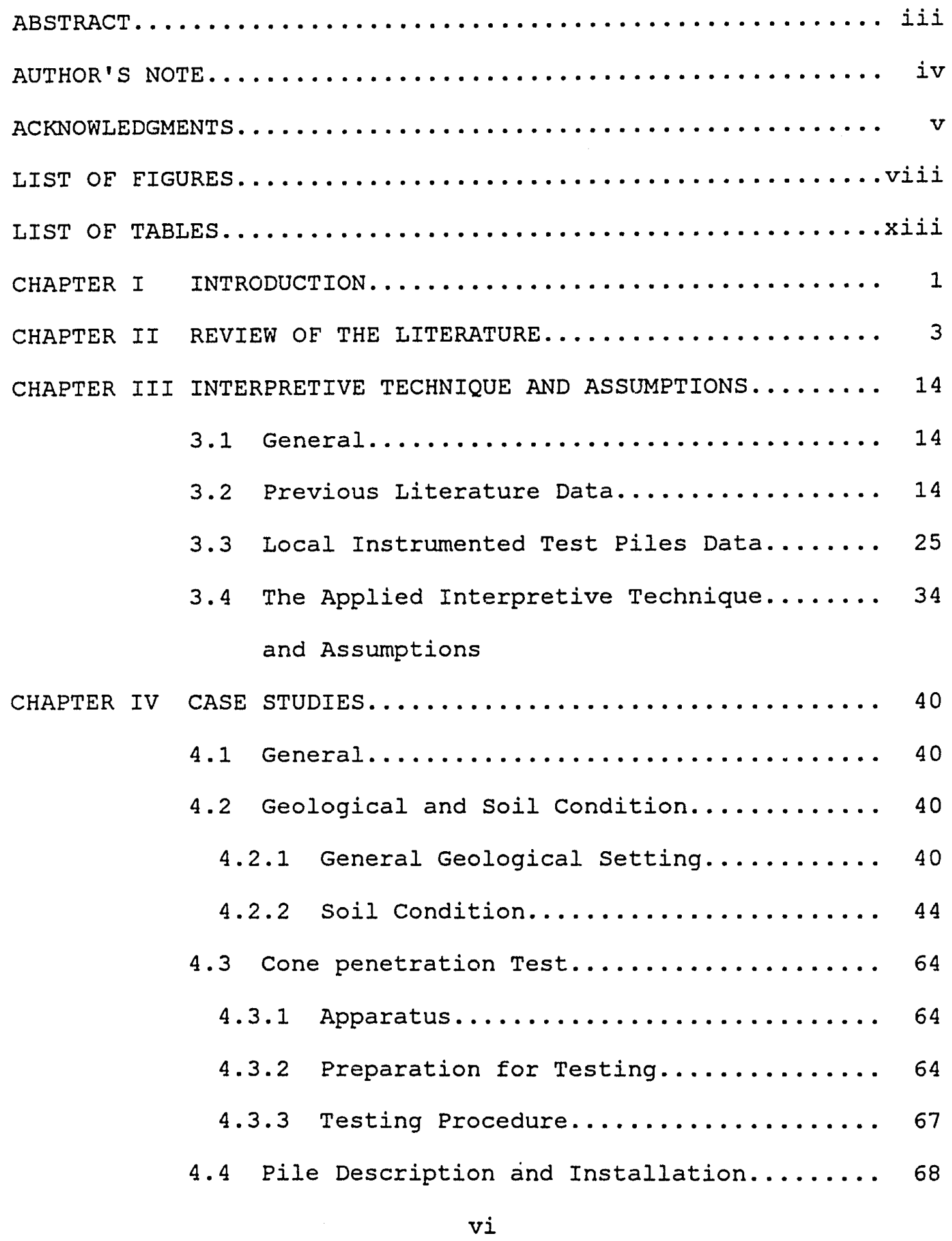


4.5 Test Loading Procedure and Results....... 69

4.6 Analysis of Data................ 89

4.7 Discussion of Results............. 91

CHAPTER $v$ CONCLUSIONS...................... 112

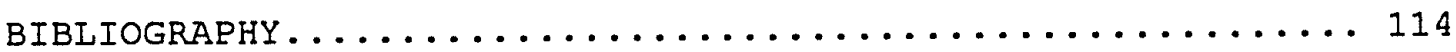

vii 


\section{IIST OF EIGURES}

Figure 2.1 Types of Bearing Pile (Redrawn After......... 4 Tomlinson, 1977)

Figure 2.2 Design Curves for Shaft Friction in Clay....... 10 Soils (Redrawn After Schmertmann, 1978)

Figure 2.3 Average Frictional Resistance, fs, versus...... 11 Adherence Coefficient, $m$ (Redrawn After

Tumay et. al., 1981)

Figure 3.1 Typical Load-Displacement Curves (After........ 15 Hirany et. al., 1989)

Figure 3.2 Dimensionless side Load-Settlement.......... 16 relation-ships (Redrawn After O'Neill

et. al., 1972)

Figure 3.3 Location of Instrumented Test Piles.......... 18 within Tributary Area of the Keelung River

Eigure 3.4 Soil Condition and Load Settlement........... 19 Curve of Test Pile A (Redrawn After MAA

Report No. TN-GESC-1-2869, 1991)

Figure 3.5 Soil Condition and Load settlement........... 20 Curve of Test Pile A (Redrawn After MAA

Report No. TN-GESC-1-3345, 1992)

Figure 3.6 Soil Condition and Load Settlement.......... 21 Curve of Test Pile A (Redrawn After MAA

Report No. TN-GESC-1-3257, 1991)

Eigure 3.7 Soil Condition and Load Settlement.......... 22 Curve of Test Pile A (Redrawn After MAA

Report No. TN-GESC-1-3288, 1992) 
Figure 3.8 soil Condition and Load settlement.......... 23 Curve of Test Pile A (Redrawn After MAA

Report No. TN-GESC-1-3367, 1991)

Figure 3.9 Soil Condition and Load Settlement.......... 24 Curve of Test Pile A (Redrawn After MAA

Report No. TN-GESC-1-950, 1989)

Figure 3.10 Observed Concrete Compression of Pile-.......28 body of Test Pile A (Redrawn After MAA

Report No. TN-GESC-1-2869, 1991)

Figure 3.11 observed Concrete Compression of Pile-....... 29 body of Test Pile A (Redrawn After MAA

Report No. TN-GESC-1-3345, 1992)

Figure 3.12 observed Concrete Compression of Pile-....... 30 body of Test Pile A (Redrawn After MAA

Report No. TN-GESC-1-3257, 1991)

Figure 3.13 observed Concrete Compression of Pile-....... 31 body of Test Pile A (Redran'n After MAA

Report No. TN-GESC-1-3288, 1992)

Figure 3.14 Observed Concrete Compression of Pile-....... 32 body of Test Pile A (Redrawn After MAA

Report No. TN-GESC-1-3367, 1991)

Figure 3.15 Observed Concrete Compression of Pile-....... 33 body of Test Pile A (Redrawn After MAA

Report No. TN-GESC-1-950, 1991)

Figure 3.16 Shaft Friction-Relative Displacement......... 37 Relationships in Cohesive Layers of Bored Piles in MRT Tamshui Line Project (Redrawn After MAA Report No. TN-GESC-1-4002, 1992)

Figure 4.1 Geological Conditions of the Taipei..........41 Basin and Its Surrounding Areas 
Figure 4.2 Location of Major Zones of Sungshan.........43 Formation

Figure 4.3 Location of Test Pile................ 45

Figure 4.4 Soil Condition at Test Pile No. $1 \ldots \ldots \ldots \ldots \ldots . \ldots 46$

Figure 4.5 Soil Condition at Test Pile No. $2 \ldots \ldots \ldots \ldots \ldots 47$

Figure 4.6 Soil Condition at Test Pile No. $3 \ldots \ldots \ldots \ldots \ldots$

Figure 4.7 Soil Condition at Test Pile No. $4 \ldots \ldots \ldots \ldots \ldots . .49$

Figure 4.8 Soil Condition at Test Pile No. $5 \ldots \ldots \ldots \ldots \ldots$

Figure 4.9 Soil Condition at Test Pile No. $6 \ldots \ldots \ldots \ldots \ldots 51$

Figure 4.10 soil Condition at Test Pile No. $7 \ldots \ldots \ldots \ldots \ldots 2$

Figure 4.11 Soil Condition at Test Pile No. $8 \ldots \ldots \ldots \ldots \ldots 53$

Figure 4.12 Soil Condition at Test Pile No. $9 \ldots \ldots \ldots \ldots \ldots . .54$

Figure 4.13 Soil Condition at Test Pile No. $10 \ldots \ldots \ldots \ldots \ldots$

Figure 4.14 Soil Condition at Test Pile No. $11 \ldots \ldots \ldots \ldots \ldots$

Figure 4.15 soil Condition at Test Pile No. 12........ 57

Figure 4.16 soil Condition at Test Pile No. 13......... 58

Eigure 4.17 soil Condition at Test Pile No. 14........ 59

Figure 4.18 Soil Condition at Test Pile No. $15 \ldots \ldots \ldots \ldots$ 
Figure 4.19 Soil Condition at Test Pile No. $16 \ldots \ldots \ldots \ldots \ldots$

Figure 4.20 soil Condition at Test Pile No. 17.........62

Figure 4.21 Soil Condition at Test Pile No. 18.........63

Figure 4.22 Mechanical Eriction-Cone Penetrometer......... 65 Tip (Begemann Type)

Eigure 4.23 Dutch Cone Penetrometer................66

Figure 4.24 Pile Load Test Result of Test Pile No. 1......70

Figure 4.25 Pile Load Test Result of Test Pile No. 2..... 71

Eigure 4.26 Pile Load Test Result of Test Pile No. 3..... 72

Figure 4.27 Pile Load Test Result of Test Pile No. 4..... 73

Figure 4.28 Pile Load Test Result of Test Pile NO. 5......74

Eigure 4.29 Pile Load Test Result of Test Pile No. 6...... 75

Figure 4.30 Pile Load Test Result of Test Pile No. 7......76

Figure 4.31 Pile Load Test Result of Test Pile NO. 8..... 77

Eigure 4.32 Pile Load Test Result of Test Pile No. 9..... 78

Figure 4.33 Pile Load Test Result of Test Pile No. 10.... 79

Figure 4.34 Pile Load Test Result of Test Pile NO. 11.....8 80

Figure 4.35 Pile Load Test Result of Test Pile NO. 12.....81

$x i$ 
Figure 4.36 Pile Load Test Result of Test Pile No. 13.....8 82

Figure 4.37 Pile Load Test Result of Test Pile No. $14 \ldots \ldots 83$

Figure 4.38 Pile Load Test Result of Test Pile No. 15.....84

Figure 4.39 Pile Load Test Result of Test Pile No. 16..... 85

Figure 4.40 Pile Load Test Result of Test Pile No. 17.....86

Figure 4.41 Pile Load Test Result of Test Pile No. 18..... 87

Figure 4.42 Comparison of $\alpha^{\prime}$ and $m$ factors.............111 


\section{IIST OF TABLES}

Table 2.1 Adhesion Factor for Bored-and-cast-......... 6 in-situ Piles in Clay (after

Tomlinson, 1977)

Table 2.2 Test Piles Data of Tumay and.............. 13 Fakhroo (after Tumay et. al., 1981)

Table 3.1 Soil Type Abbreviations.................. 26

Table 3.2 Calculated Elastic Deformations of........... 35 Instrumented Piles

Table 4.1 Shaft Erictional Capacity............... 92 Calculation of Test Pile No. 1

Table 4.2 Shaft Frictional Capacity................ 93 Calculation of Test Pile No. 2

Table 4.3 Shaft Frictional Capacity................ 94 Calculation of Test Pile No. 3

Table 4.4 Shaft Frictional Capacity............... 95 Calculation of Test Pile No. 4

Table 4.5 Shaft Frictional Capacity................ 96 Calculation of Test Pile No. 5

Table 4.6 Shaft Erictional Capacity................ 97 Calculation of Test Pile No. 6

Table 4.7 Shaft Erictional Capacity............... 98 Calculation of Test Pile No. 7

Table 4.8 Shaft Erictional Capacity............... 99 Calculation of Test Pile No. 8 


\section{PLEASE NOTE}

Page(s) missing in number on $1 y$; text follows. Filmed as received.

$$
\text { xiv, xv, xvi, xvii, xviii }
$$

University Microfilms International 
Table 4.9 Shaft Frictional Capacity..................100 Calculation of Test Pile No. 9

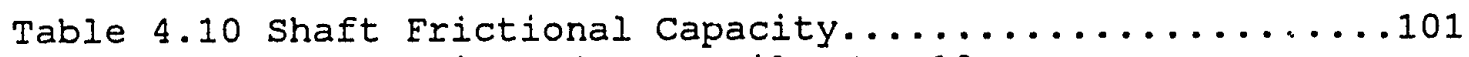
Calculation of Test Pile No. 10

Table 4.11 Shaft Erictional Capacity................... 102 Calculation of Test Pile No. 11

Table 4.12 Shaft Frictional Capacity.................103 Calculation of Test Pile No. 12

Table 4.13 Shaft Frictional Capacity..................104 Calculation of Test Pile No. 13

Table 4.14 Shaft Erictional Capacity..................... Calculation of Test Pile No. 14

Table 4.15 Shaft Frictional Capacity.................106 Calculation of Test Pile No. 15

Table 4.16 Shaft Erictional Capacity.................107 Calculation of Test Pile No. 16

Table 4.17 Shaft Frictional Capacity................108 Calculation of Test Pile No. 17

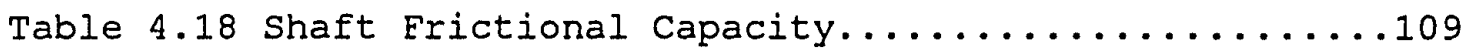
Calculation of Test Pile No. 18

Table 4.19 Analysis of Erictional Capacity.............111 
CHAPTER I

INTRODUCTION

The determination of pile bearing capacity from in-situ penetration test results (Standard Penetration Test and Cone Penetration Test) using empirical approaches, has been widely used. The problem of estimating pile capacity, however, is complicated by the soil characteristics, pile types and installation procedures. The effect of these influencing factors is difficult to predict by analytical techniques due to the complex phenomenon of soil-pile interaction. Load tests are helpful in verifying the estimated pile capacity. Recently, large diameter cast-in-place bored piles constructed with the reverse circulation drilling technique have increasingly been used in Taipei, primarily due to their relatively low cost, low noise and low vibration levels. The objective of this thesis is to compare the loading capacity of axially loaded piles, as indicated by full-scale field load tests, to predicted frictional capacity which contributes the major portion of the load carrying capacity of 
piles installed in cohesive soils, utilizing the results of the Cone Penetration Test. A series of eighteen cast-in-place reverse circulation bored piles located in Taipei Basin, where subsurface conditions consist of clayey sedimentary deposits, where loaded. These loading values are then compared to the predicted values utilizing the results of the Cone Penetration Test performed at the sites, following the method suggested by Schmertmann (1978), and Tumay and Fakhroo (1981). This thesis demonstrates that the present state-of-the-art methods for utilizing Cone Penetration Test data for pile frictional capacity prediction in cohesive soils agree reasonably well with the observed carrying capacity of the tested poles when using the method suggested by Tumay et.al. However, the method suggested by Schmertmann tends to underestimate the load carrying ability of the piles in this region. 
CHAPTER II

REVIEW OE THE IITERATURE

The basis of the soil mechanics approach to calculating the carrying capacity of an axially loaded pile is that the total resistance of the pile to compression loads is the sum of two components, namely skin friction and end resistance. A pile bearing on rock or some other hard incompressible material is known as an end-bearing pile (Figure 2.1a), while a pile in which the skin-frictional component predominates is known as a friction pile (Figure 2.1b).

For an end bearing pile, the total end bearing capacity can be expressed as

$\begin{aligned} \mathrm{Qp} & =\mathrm{Ap} \mathrm{qp} \\ \text { where } \quad \text { Qp } & =\text { total end bearing capacity } \\ \mathrm{Ap} & =\text { area of pile cross section } \\ \mathrm{qp} & =\text { unit end resistance }\end{aligned}$

While for a friction pile in cohesive soils, the total 

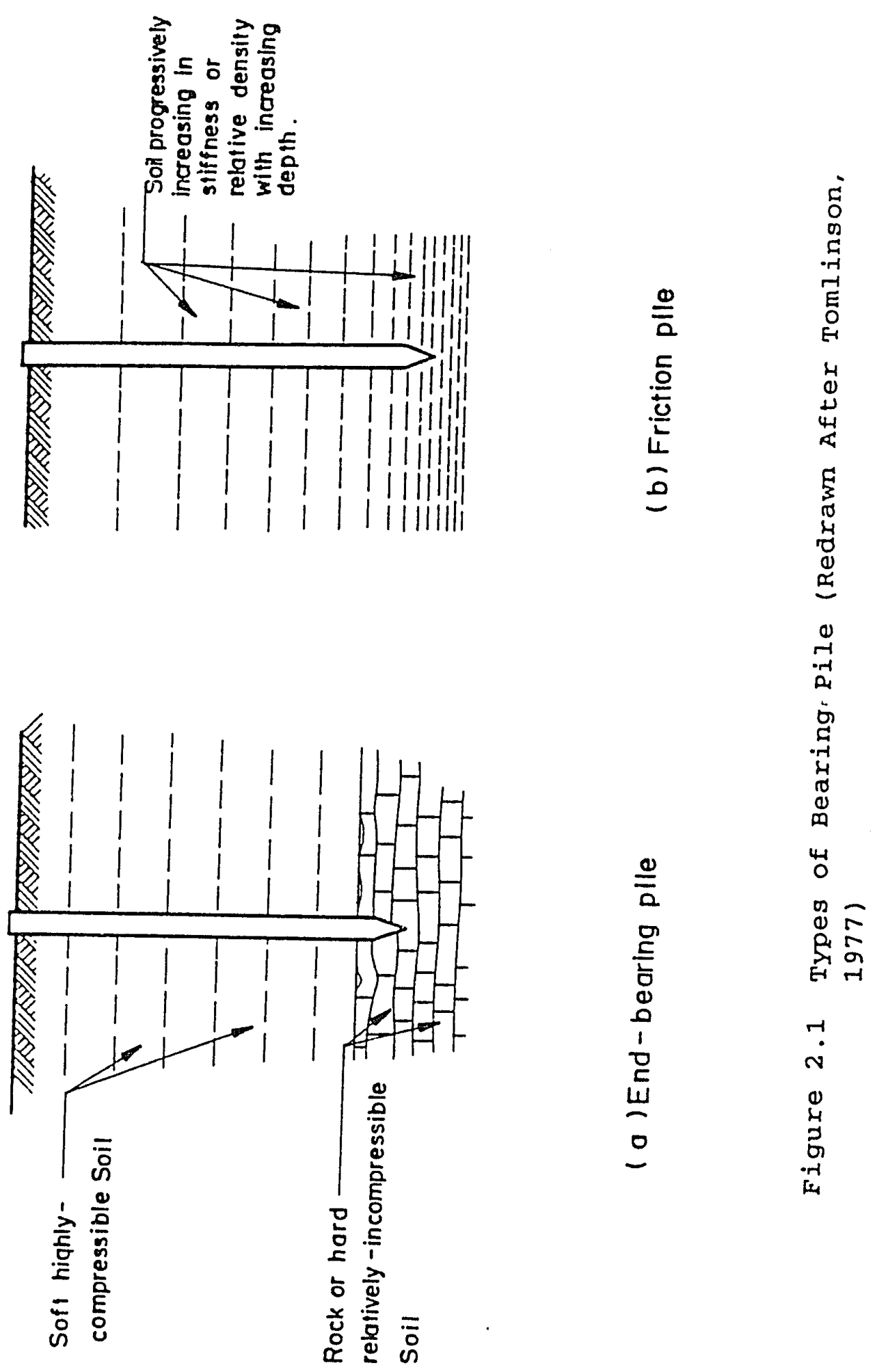
shaft adhesion, Qs acting on a pile may be expressed as

$$
\text { Qs } \quad=\pi \mathrm{D} \int_{0}^{L} \mathrm{f} d L
$$

where

$$
\begin{array}{ll}
\mathrm{D} & =\text { pile diameter } \\
\mathrm{L} & =\text { pile length } \\
\mathrm{f} & =\text { unit shaft adhesion } \\
\mathrm{dL} & =\text { length of a pile element }
\end{array}
$$

In the present state of knowledge, the effect of the various methods of pile installation on the carrying capacity and deformation characteristics can hardly be calculated by the strict application of soil or rock mechanics theory. One of the ways that it can be done is to apply simple empirical factors to the shear strength of the undisturbed soil or to the in-situ test parameters. These empirical factors are generally dependent on the particular method of installation and are based on experience and on the results of field loading tests. The unit shaft adhesion, $f$ in cohesive soils is normally predicted using a total stress approach in which the undrained shear strength of the clay, su is multiplied by an empirical adhesion factor $\alpha$, i.e.

$$
\mathrm{f} \quad=\alpha \mathrm{Su}
$$



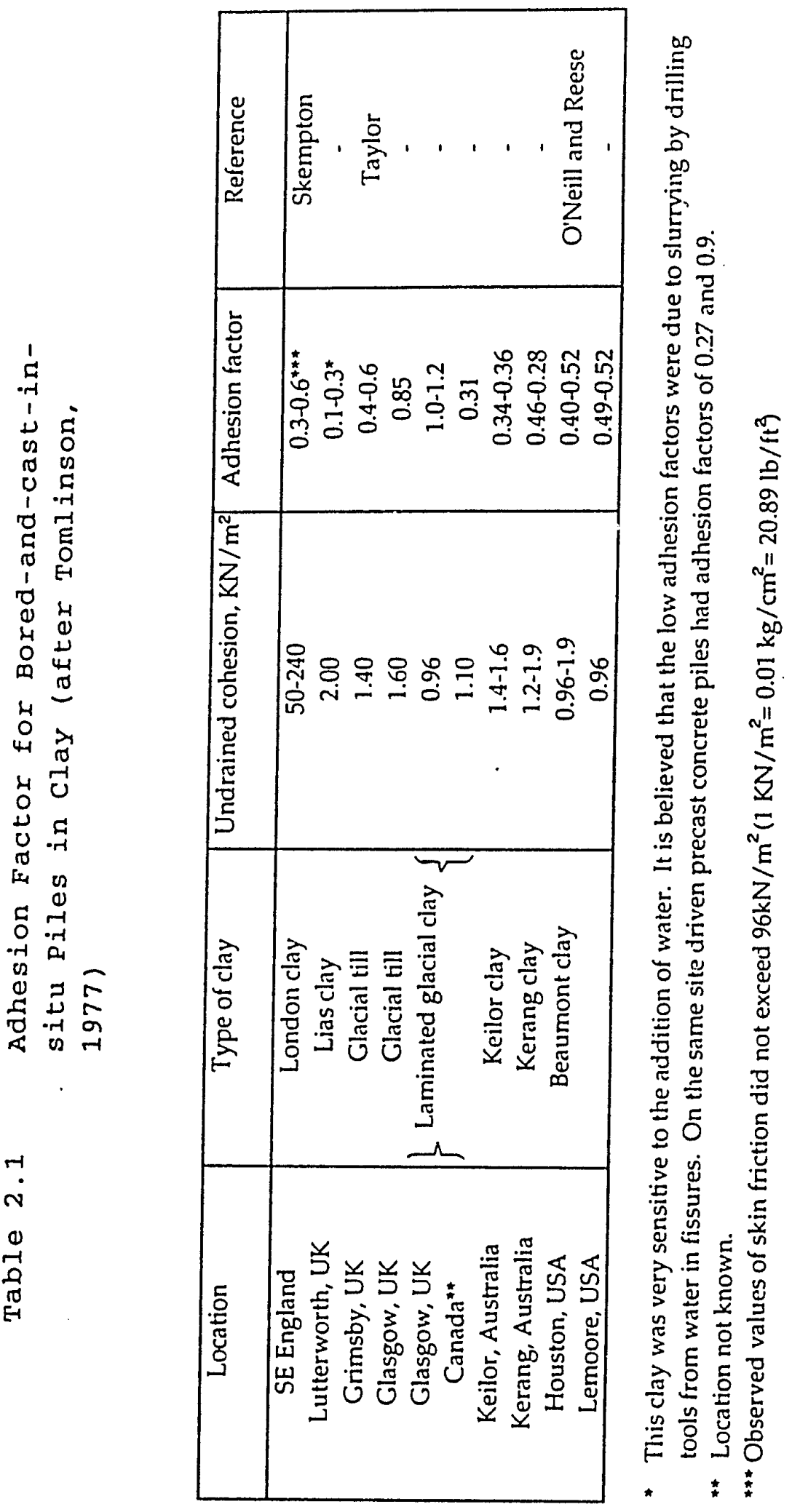
Experience from pile tests has provided a variety of the adhesion factor $\alpha$ as shown in Table 2.1, where the value of $\alpha$ can vary from 0.1 to 1.2 depending on soil type and strength (Tomlinson, 1977). The most common method used by the engineers in Taiwan is that presented by skempton, who suggested that the $\alpha$ value varied from 0.6 for long piles, with favorable geological conditions and careful workmanship, to 0.3 for very short piles and with unfavorable conditions, with an average value of 0.45 (Skempton, 1959).

Although the above method for shaft adhesion estimation appears straight forward it does have major difficulties. At the center of these is the problem of measuring the undrained strength, su. The fact is that there is no unique value of su for a soil element. Its value depends on many factors such as the orientation of the stresses, the rate of testing, the size of the specimen and the test method. Moreover values on Su, whether determined in the laboratory or in the field, frequently show a wide scatter.

Many investigators now believe that the cone frictional resistance, fs, data obtained from the Cone Penetration Test provides a better indication of the undrained shear strength, su of cohesion, f. Experimental correlation of fs and su presented by Wesley (1967) indicated fs to be slightly higher than su. Begemann (1965) and Vesic (1967) suggested that fs may be taken as equal to or half of the unit shaft adhesion, $f$ of piles, 
respectively. Nottingham (1975) applied Tomlinson's adhesion factor, $\alpha$ to relate $f$ to average fs values. He assumed undrained cohesion, su to be equal to fs.

In this thesis, the intent is to use the cone frictional resistance, fs, data for directly estimating the unit shaft adhesion $f$, in cohesive soils. Two experimental correlations are compared:

1) $\alpha^{\prime}$ method suggested by Schmertmann (1978), and

2) Cone-m Method suggested by Tumay and Fakhroo (1981).

Schmertmann's Method

The computation of shaft adhesion in cohesive soils using the mechanical Cone Penetration Test data, as described by Schmertmann, follows the relationship expressed as

Es $\quad=\quad \alpha^{\prime}$ fsAs

$\begin{aligned} \text { where } & =\text { total ultimate shaft friction } \\ \alpha^{\prime} & =\text { ratio of pile to penetrometer sleeve } \\ & \text { friction in clay, as shown in Figure } \\ & 2.2 \\ \text { fs } \quad & \text { average undrained sleeve friction of } \\ & \text { cone }\end{aligned}$


As $=$ total soil-pile contact area

This recommendation was based primarily on an evaluation of the results from the model and full-scale pile studies done by Nottingham in 1975.

Tumay and Fakhroo's Method

The same relationship between shaft adhesion and average cone friction was suggested by Tumay and Fakhroo as

ES $=\mathrm{m}$ ES AS

where $\mathrm{m}=$ adherence coefficient, as shown in Eigure 2.3

The correlation in Figure 2.3 was obtained based on field load tests of 37 test piles of various shapes, size and material, as shown in Table 2.2, driven in soft cohesive soils with the mean su ranging from $0.21 \mathrm{~kg} / \mathrm{cm}^{2}$ to $1.1 \mathrm{~kg} / \mathrm{cm}^{2}$ throughout 10 sites in Louisiana.

The cone penetration tests were conducted utilizing the Fugro electronic cone penetrometer with a cone of 60 degree point angle and 10 square centimeters base area penetration at 


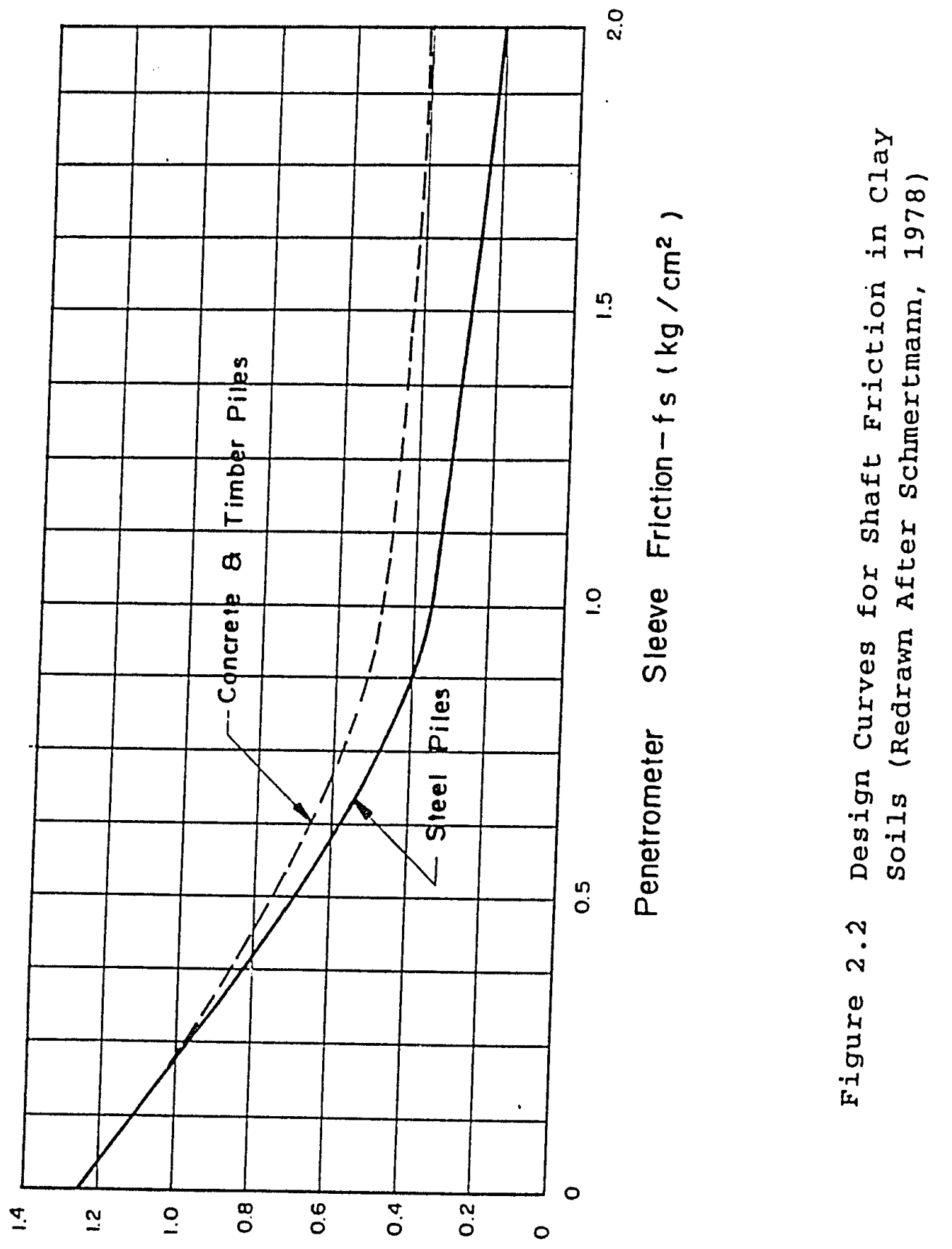

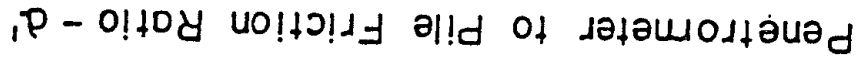




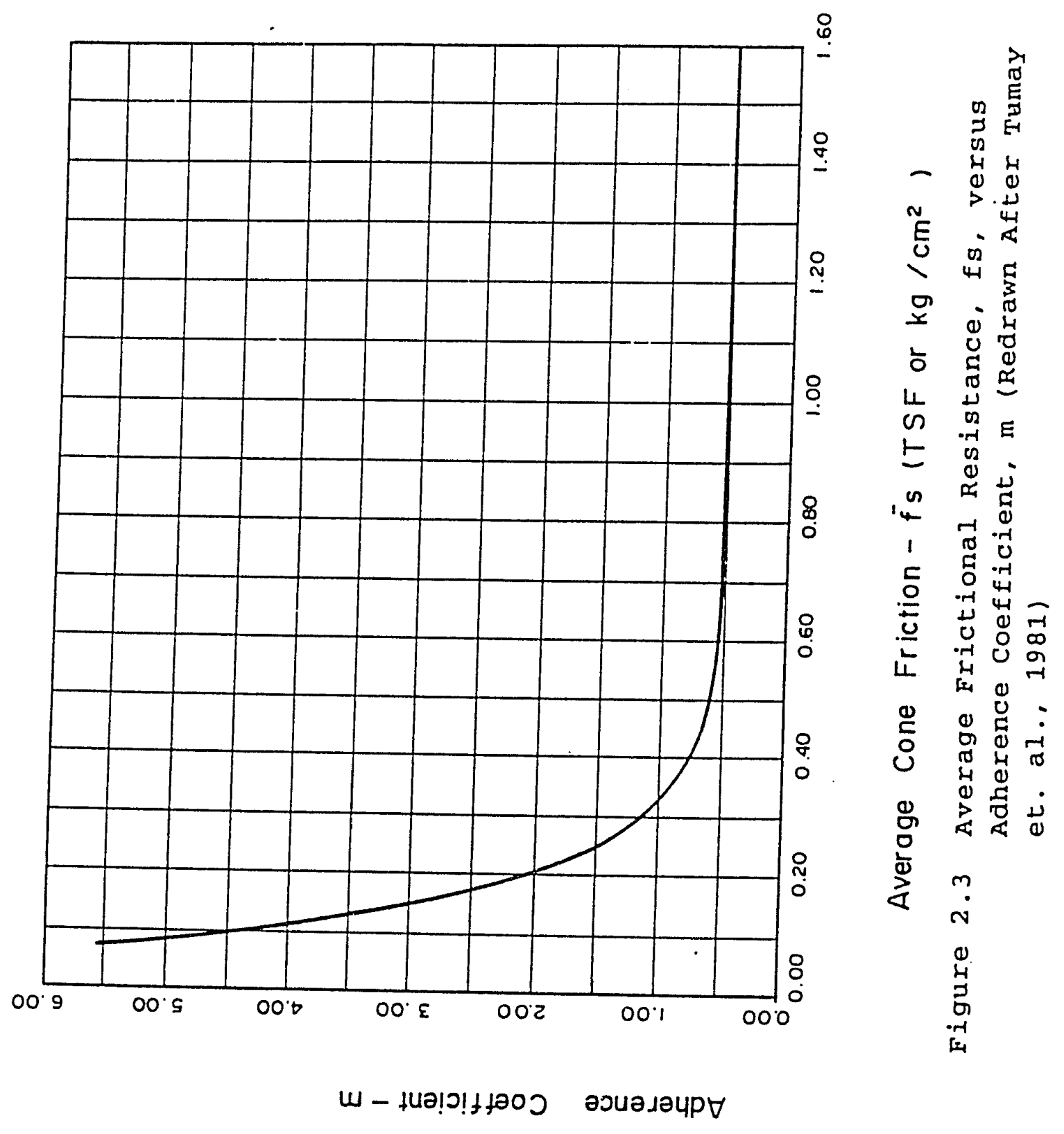


the rate of $2 \mathrm{~cm} / \mathrm{sec}$.

According to Tumay et. al., the data points shown in Figure 2.3 were the average values of the 10 sites, and the individual test pile data fitted the $m$ curve very closely. The algebraic mean of the prediction error (predicted-measured)/measured was reported to be -2.08 with standard deviation of 11.58 . Tumay et. al. based on the curve fitting process indicated that the $m$ curve could be expressed by the equation:

$$
m \quad=10.0-9.5\left(1-e^{-9.0 f s}\right)
$$

The above expression suggested that the adherence coefficient, $m$, could vary between 10.0 and 0.50 . Tumay et. al. suggested an upper limit of $0.75 \mathrm{~kg} / \mathrm{cm}^{2}$ for the unit pile friction, $\mathrm{f}$. 
Table 2.2

Test Piles Data of Tumay and Fakhroo (after Tumay et. al., 1981)

\begin{tabular}{|c|c|c|c|c|c|}
\hline No. & $\begin{array}{l}\text { Test } \\
\text { Pile }\end{array}$ & Location & Shape & $\begin{array}{l}\text { Embadded } \\
\text { Lenglh } \\
\text { (fi) }\end{array}$ & $\begin{array}{c}\text { Ullimale } \\
\text { Lond (Q) } \\
\text { (Ton) }\end{array}$ \\
\hline 1 & 1 & New Orlcails (I) & 18" Square (C) & 120 & 345 \\
\hline 2 & $2 \mathrm{~A}$ & New Orleans (1) & Step Taper (S) & 123 & 190 \\
\hline 3 & 3 & New Orlenus (1) & Monotube (S) & 123 & 275 \\
\hline 4 & 4 & New Orleans (I) & Slcp Taper (S) & 123 & 200 \\
\hline 5 & 5 & New Oricans (I) & 16" Dia. Гipe (S) & 123 & 320 \\
\hline 6 & 6 & New Orleans (IIA) & $16^{\prime \prime}$ Square (C) & 100 & 225 \\
\hline 7 & 8 & New Orleans (\|IA) & 20" Trinugle (C) & 100 & 240 \\
\hline 8 & 9 & New Orleairs (IIA) & Step Taper (S) & 102 & 135 \\
\hline 9 & 10 & New Orlenis (IIA) & Slep Tnper (S) & 137 & 205 \\
\hline 10 & 11 & New Oricanss (\|IA) & Monolube (S) & 102 & 180 \\
\hline 11 & 12 & Neiv Orleans (IIA) & Monotube (S) & 137 & 240 \\
\hline 12 & 13 & Neiv Orlenins (IIA) & Step Tnper (S) & 102 & 135 \\
\hline 13 & 14 & New Orlenus (lla) & Slcp Tnper (S) & 137 & 2015 \\
\hline 14 & 15 & New Orlcans (IIA) & 14" Din. Pipc (S) & 102 & 180 \\
\hline 15 & 16 & New Orlenus (IIA) & 16" Din. Pipe (S) & 137 & 240 \\
\hline 16 & 18 & New Orienns (IIA) & Slep Tnper (S) & 101 & 175 \\
\hline 17 & 19 & New Orleans (IIA) & Stcp Taper (S) & 138 & 2000 \\
\hline 18 & 1 & Houms & 18" Square (C) & 95 & 200 \\
\hline 19 & 2 & Houmn & 12" Din. Pipe (S) & 95 & 260 \\
\hline 20 & 3 & Houma & 14" Din. Pipe (S) & 95 & 130 \\
\hline 21 & 4 & Houmn & slcp Tnper (S) & 95 & 195 \\
\hline 22 & 5 & Huunin & Sicp Tiper (S) & 152 & 255 \\
\hline 23 & 10 & Houma & Monolube (S) & 95 & 175 \\
\hline 24 & $24-1$ & Ruddock & $24^{\prime \prime}$ Squnre (C) & 65 & 250 \\
\hline 25 & $30-1$ & Ruddock & 30" Square (C) & 65 & 330 \\
\hline 26 & $24-2$ & Ruddock & 24" Siquare (C) & 90 & 380 \\
\hline 27 & $30-2$ & Ruddock & 30" Square (C) & 80) & 600 \\
\hline 28 & $54-2$ & Ruddock & 54" Round (C) & 83 & $7(x)$ \\
\hline 29 & $4 \mathrm{~A}$ & Morgan Cily & Slcp Tinper (S) & 120 & 180 \\
\hline 30 & $4 B$ & Morgan City & Step Taper (S) & 108 & 170 \\
\hline 31 & $2 \mathrm{~A}$ & Balon Rouge (l) & $14 "$ Sipuare (C) & 45 & 170 \\
\hline 32 & $4 \mathrm{~A}$ & Baton Rouge (IIA) & 14" Siquare (C) & 43 & 165 \\
\hline 33 & 1 & Alexandrin & 14" Sijuare (C) & 31 & 105 \\
\hline 34 & 3 & Alexnndrin & 14" Syuare (C) & 45 & 140 \\
\hline 35 & 2 & Burgie (1) & 36" Squהre (C) & 124 & $5(11)$ \\
\hline 36 & 4 & Burgne (II) & 36" Siquare (C) & 130 & 520 \\
\hline 37 & 5 & Borgne (II) & 24" Syuare (C) & 104 & 320 \\
\hline
\end{tabular}

Nolc: 1. (C) means Concrele

(S) means Stcel

2. $11 \mathrm{t}=0.3048$ meler, 1 Ton $=2205 \mathrm{lbs}$. 
CHAPTER III

INTERPRETIVE TECHNIQUE AND ASSUMPTIONS

\subsection{General}

Load-displacement curves obtained from axial compression tests on deep foundations can exhibit any one of the three shapes shown in Figure 3.1. The peak of $A$ and the asymptote of $B$ give the maximum resistance of the foundation. However, if the load-displacement curve resembles $C$, the maximum resistance of the foundation is difficult to evaluate. Drilled shaft data often resemble C (Hirany and Kulhawy, 1989).

In this thesis, the intent is to define the maximum shaft resistance of bored piles based on the amount of pile displacement from pile load test data.

\subsection{Previous Literature Data}

Dimensionless side load versus mean settlement relationship 


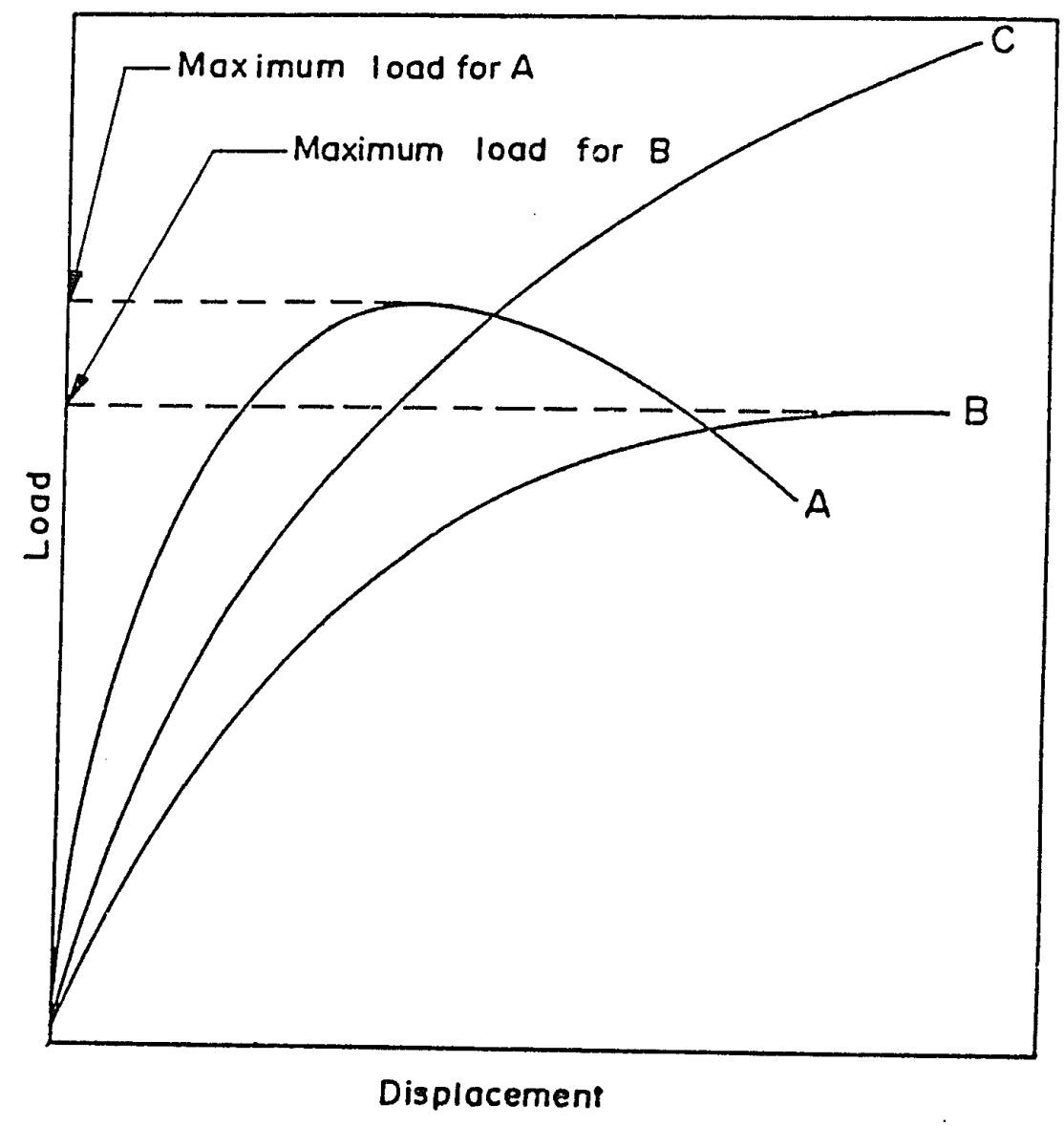

Figure 3.1. Typical Load-Displacement Curves (After Hirany et. al., 1989) 


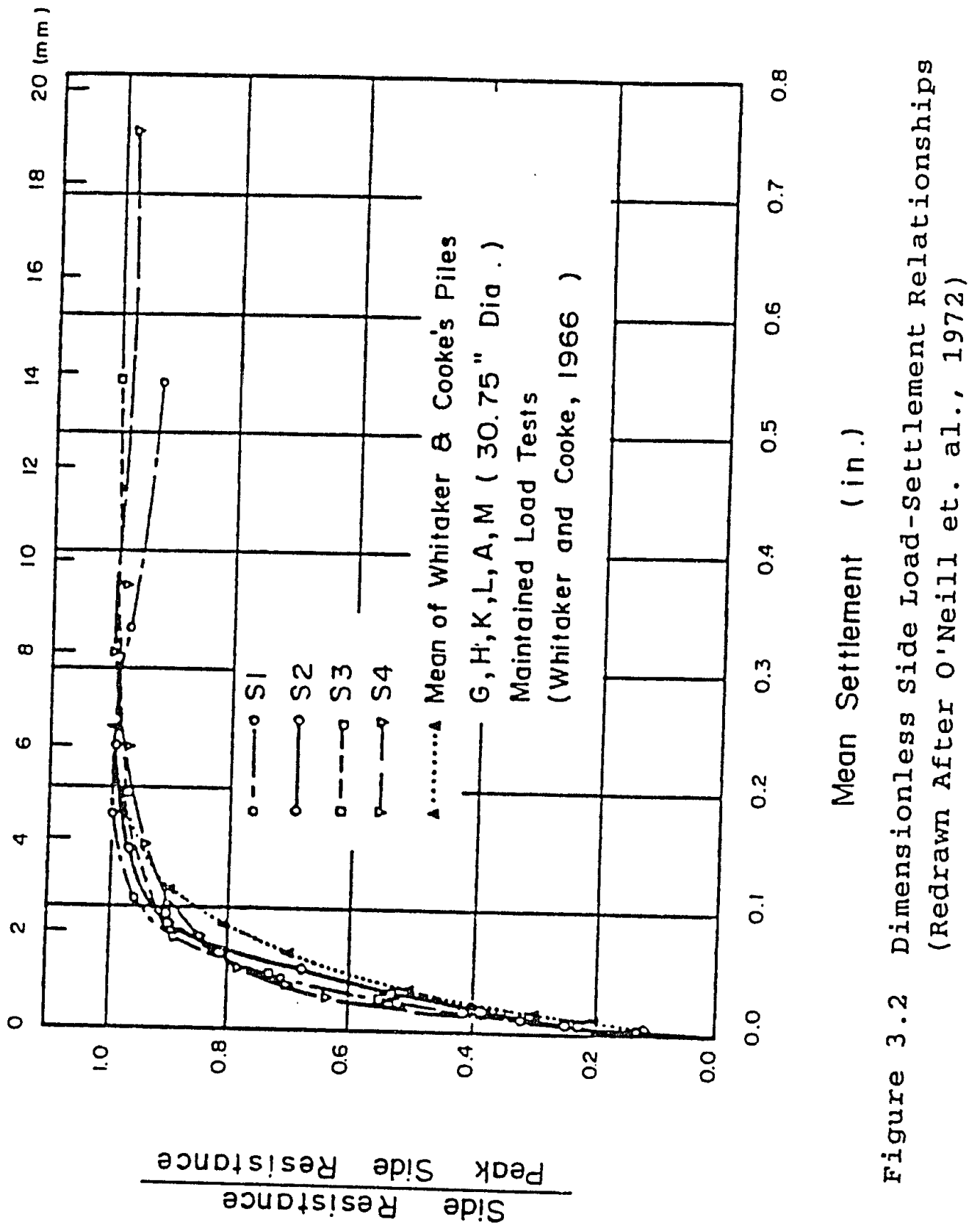


is presented in Figure 3.2 on the basis of large scale tests on bored piles reported by O'Neill and Reese (1972). In this figure, mean settlement, i.e., the average of butt and base settlement was used; it was reported that very little concrete compression existed, and that the butt and base settlements were nearly equal.

As can be seen, Figure 3.2 shows that the slip to develop maximum skin resistance is on the order of 5 to $10 \mathrm{~mm}$; Bowles (1988) referred to the study by $O$ 'Neill and Reese and reported that this amount of slip was relatively independent of shaft diameter and embodiment length. Bowles also reported that the mobilization of the ultimate end resistance required an end displacement on the order of 10 to 30 percent of the base diameter for bored piles. 


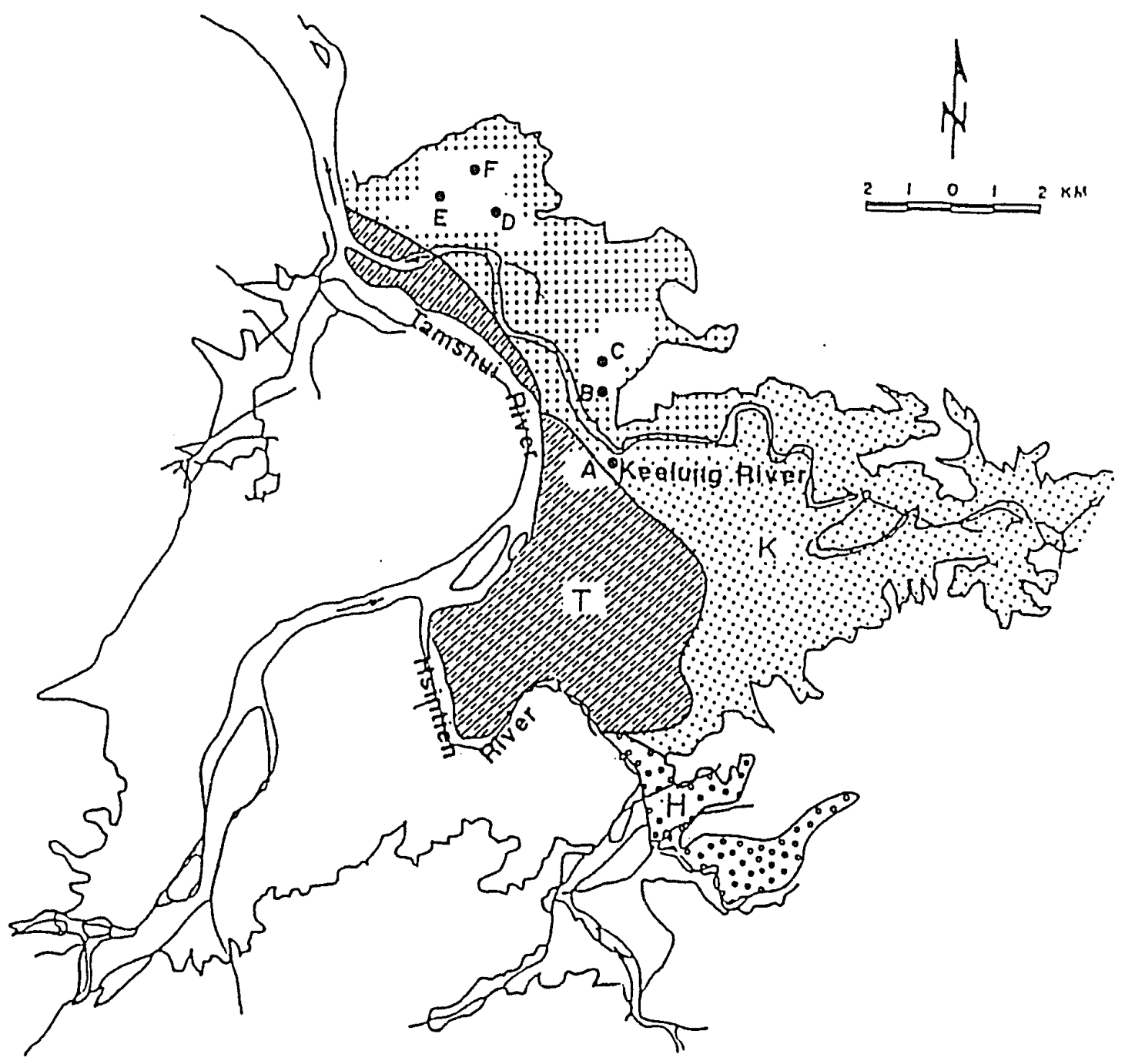

Note:

$T$ : Tomshui River Zone

$H$ : Hsintien River Zone.

$K$ : Keelung River Zone.

- : A F Test Piles.

Figure 3.3 Location of Instrumented Test Piles within
Tributary Area of the Keelung River 

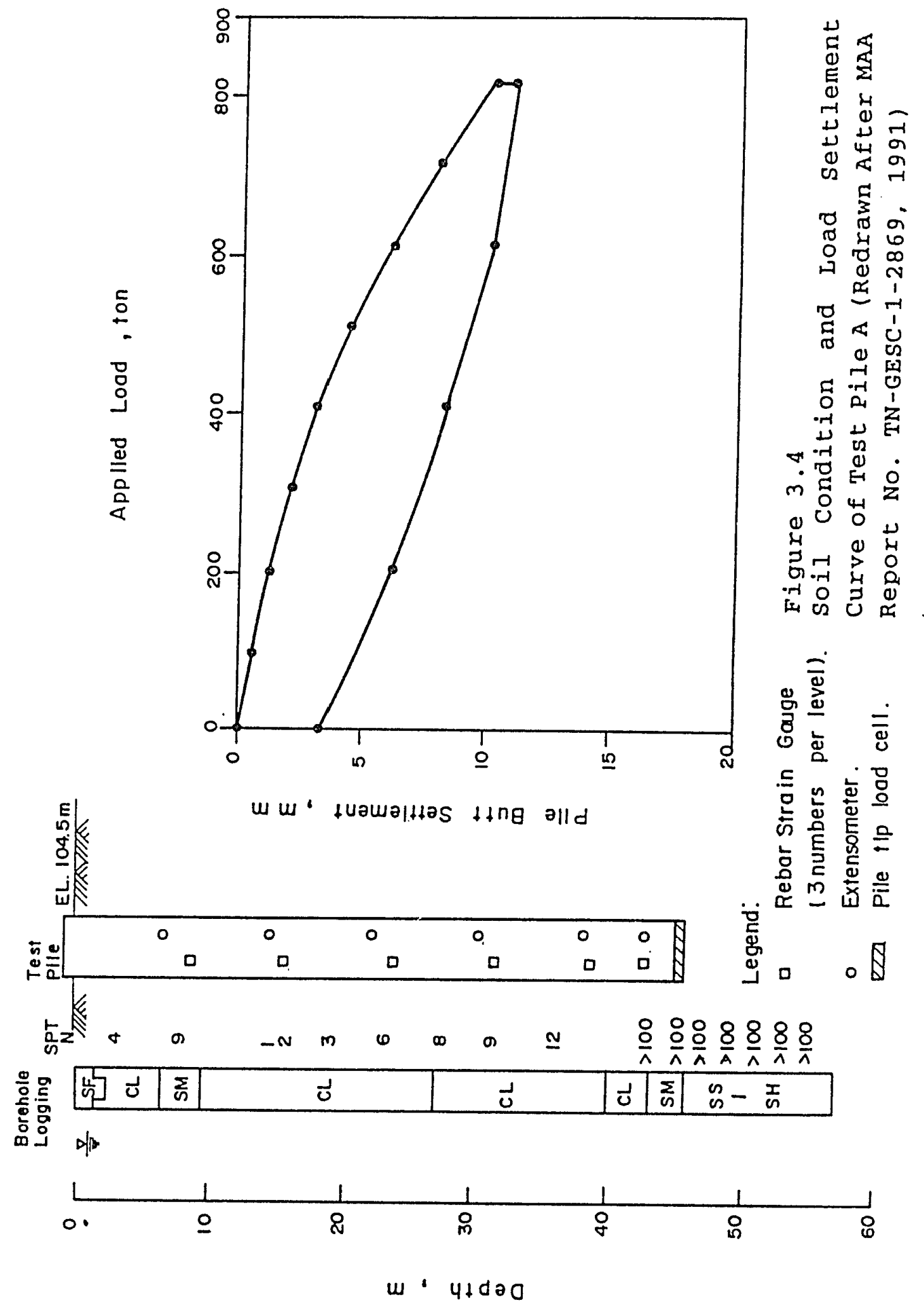

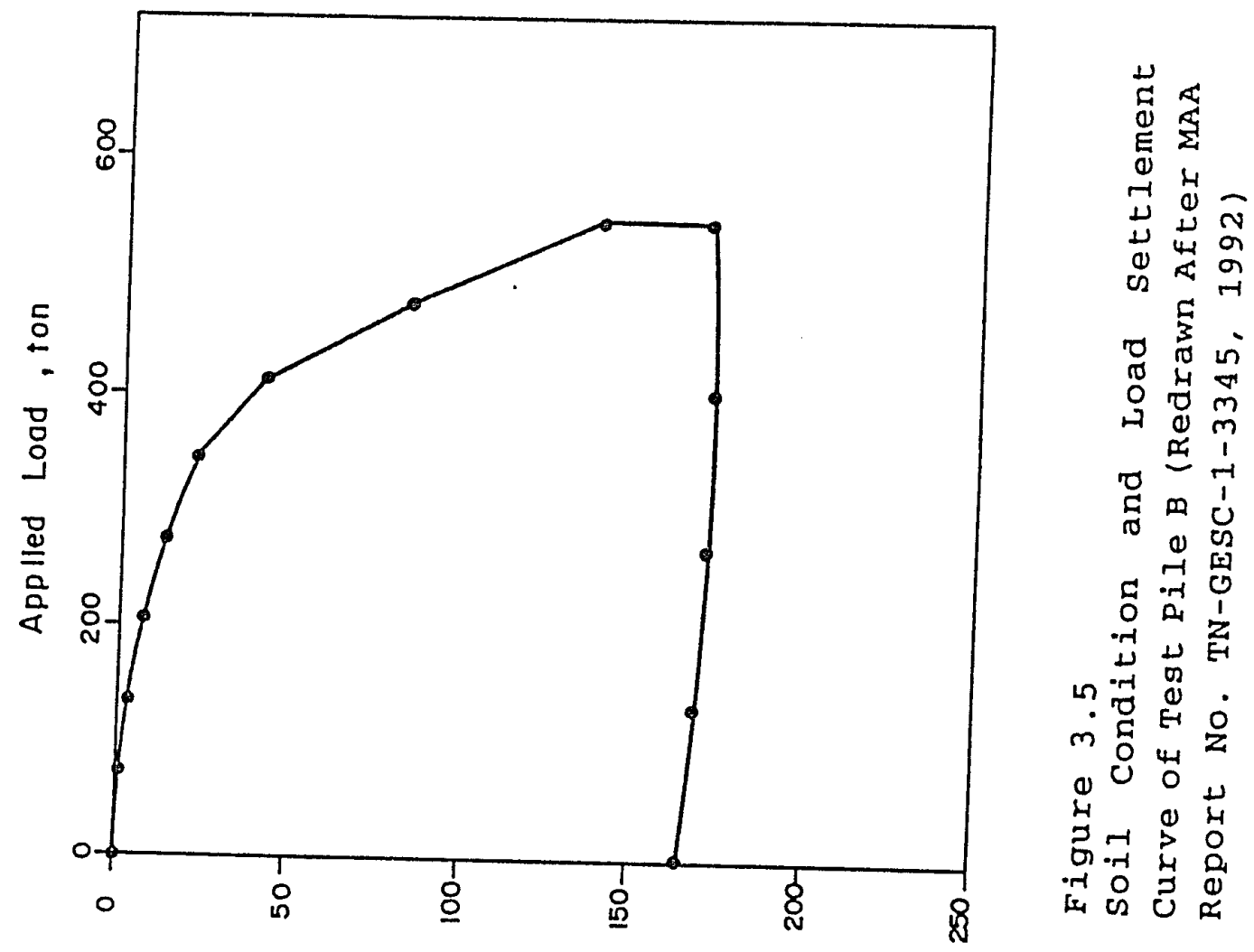

$w w^{\prime}$. tuawalttas t\$ng alld
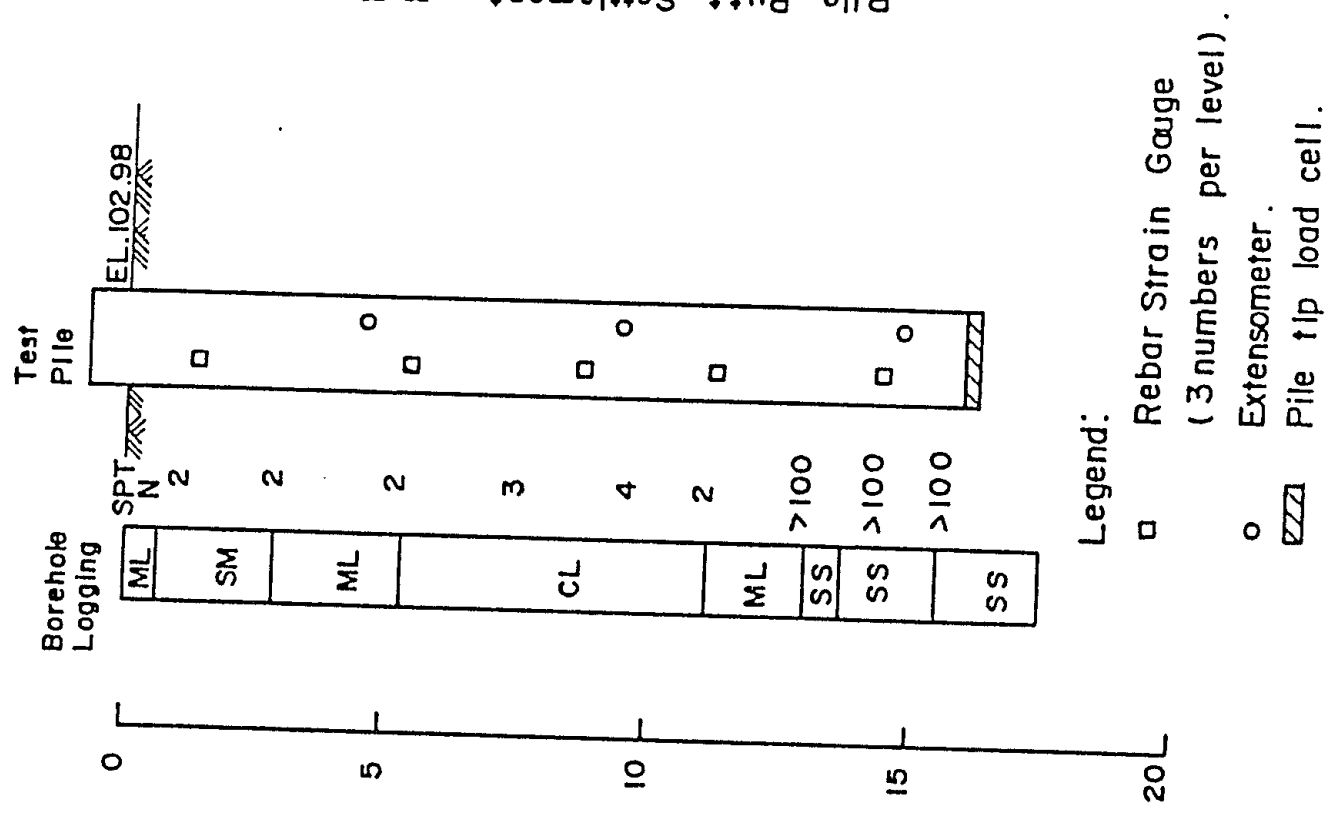

$w \cdot 4+d \partial 0$ 

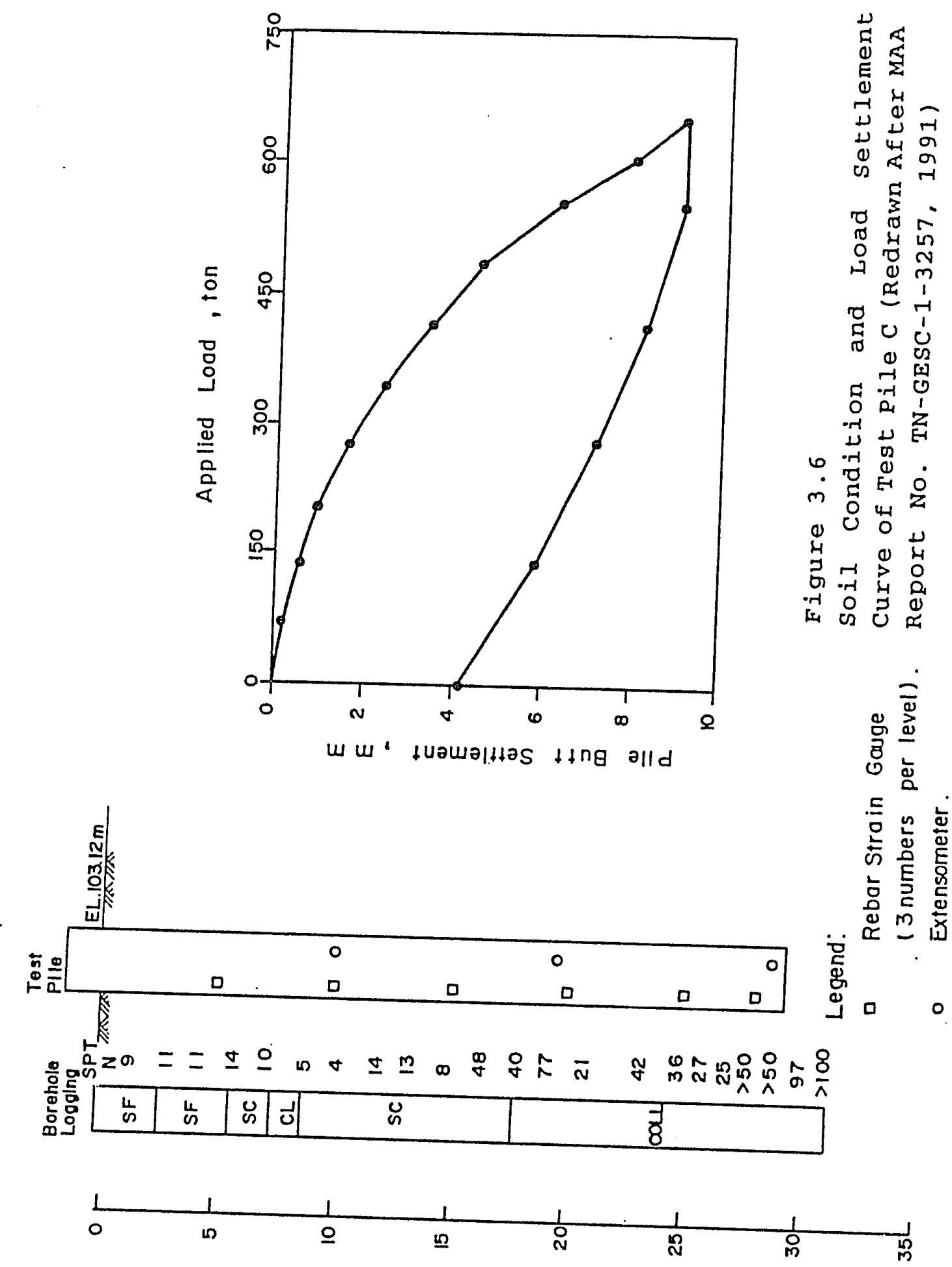

w. 4tda, 


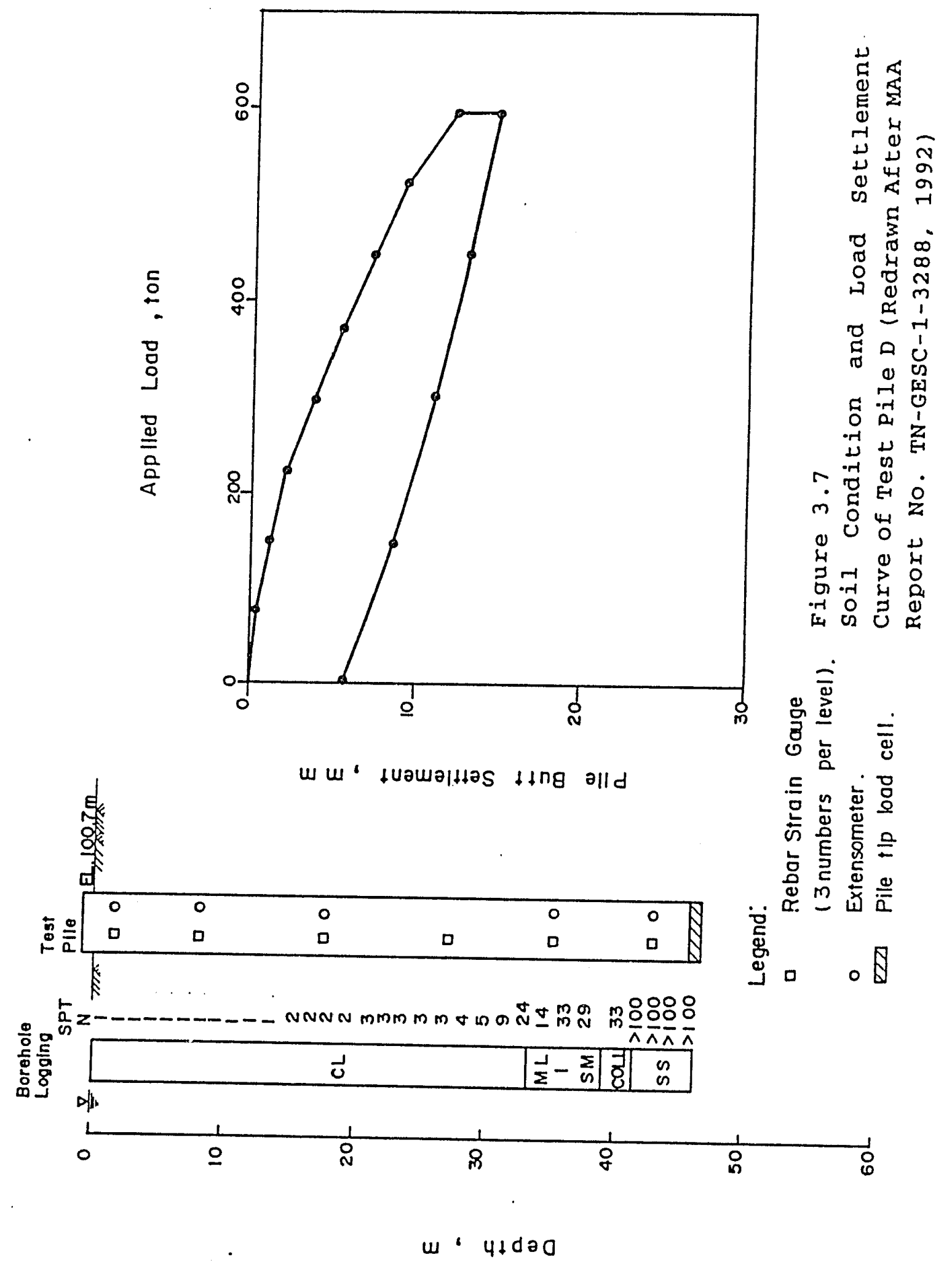



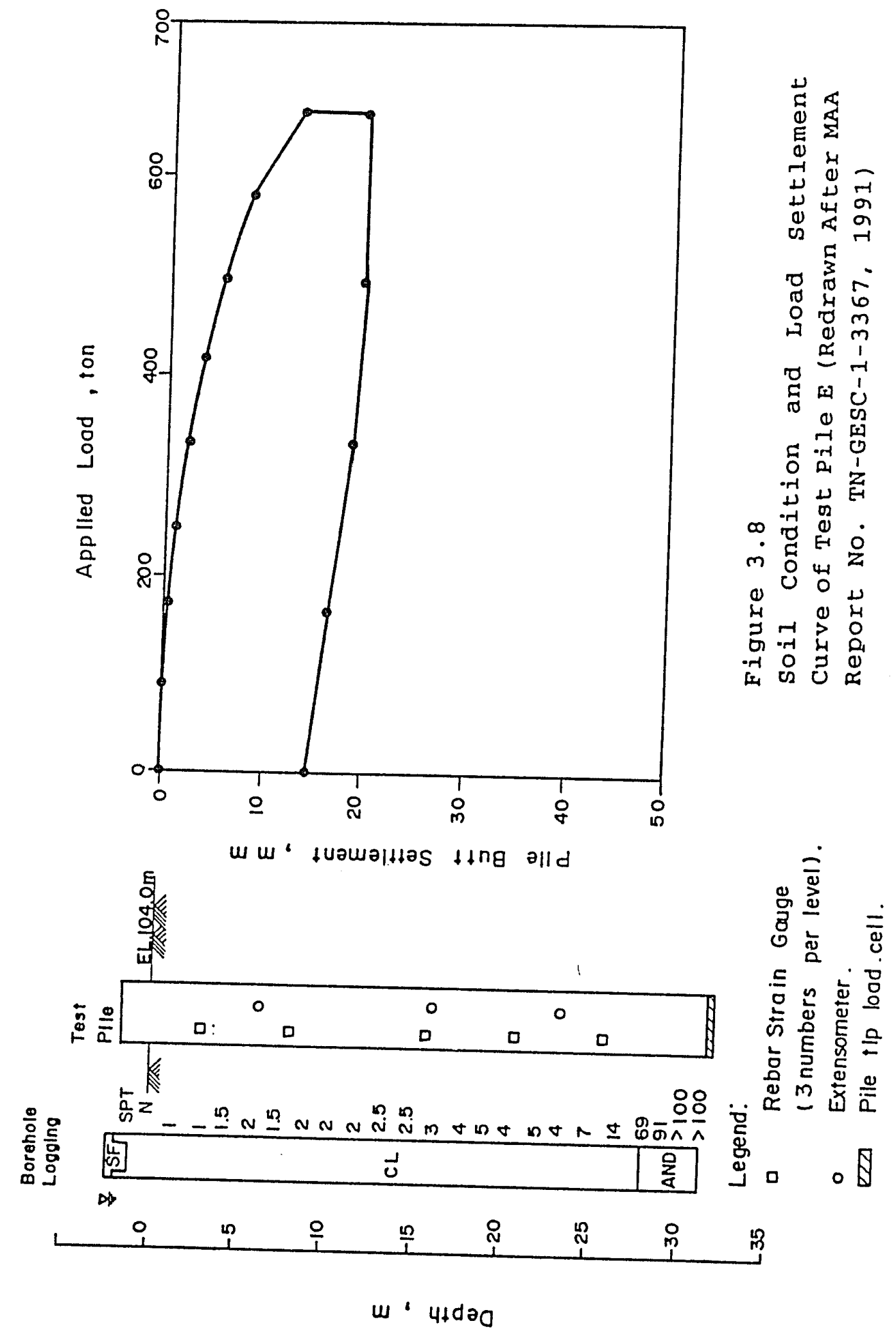

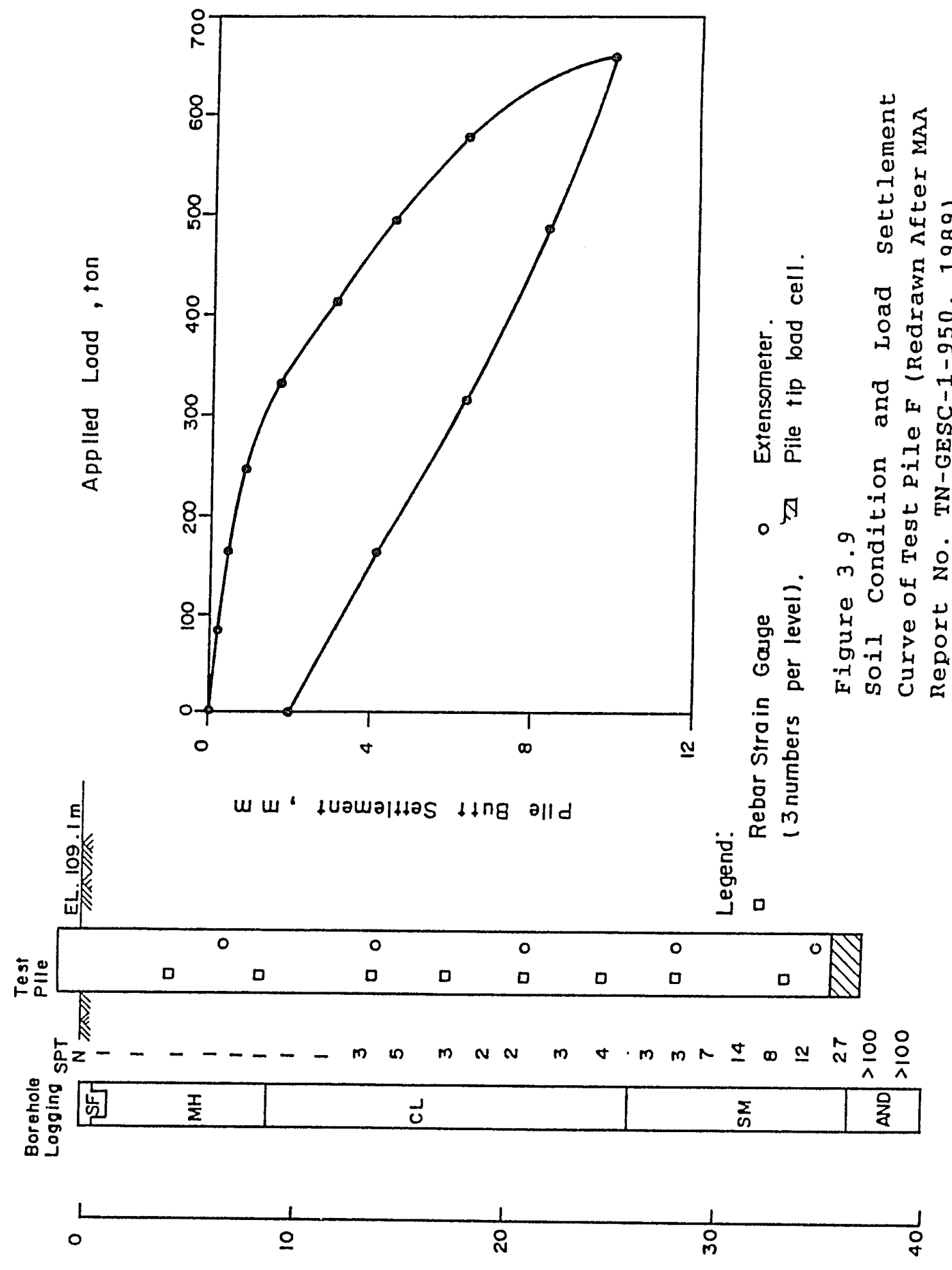

$w \cdot 4+d a 0$ 


\subsection{Local Instrumented Test Piles Data}

A total number of six instrumented, cast-in-situ, bored piles were tested within the tributary area of the Keelung River in Taipei Basin, as shown in Figure 3.3. The soil conditions for each location of test piles are as shown in Figures 3.4 through 3.9, with soil type abbreviations as shown in Table 3.1 . Among the instrumented test pile, pile-tip-load-cells were installed at piles A, B, D, E and E. To ensure a good contact between the cylindrical load cell body and the soil, a cement grout was injected from the ground surface prior to pile concreting, through a pipe fixed in the reinforcement, into the void between load cell and the bottom of hole.

The procedure for conducting the load tests was generally in accordance with ASTM D1143, where loads were applied in eight equal increments up to a maximum test load, and then unloaded in four equal decrements. Detailed graphical presentations of the load-settlement curves are also shown in Figures 3.4 through 3.9. 


\section{PLEASE NOTE:}

Page(s) missing in number only; text follows. Filmed as receivod. 
Eigure 3.10 through 3.15 show the observed concrete compression of the pile-body of the instrumented test piles. Theoretical elastic deformation for an assumed end-bearing pile can be calculated using the simple formula as

$$
\Delta \quad=\quad \mathrm{PI} / \mathrm{AE}
$$

where $\begin{array}{ll}\Delta & =\text { elastic deformation } \\ \text { P } & =\text { the applied load } \\ \text { I } & =\text { length of the pile } \\ \text { A } & =\text { cross-sectional area of the pile } \\ \text { E } & =\text { elastic modules of the pile }\end{array}$

A friction pile with uniform stress distribution to the soil throughout the length of the pile will have an elastic deformation of one-half of the above. The elastic deformations for the six instrumented piles are considered as friction piles, i.e.:

$$
\Delta \quad=\quad \mathrm{PL} / 2 \mathrm{AE}
$$

with the elastic modules of pile, $E=2.1 \times 10^{6} \mathrm{~T} / \mathrm{m}^{2}$. Table 3.2 shows the calculated elastic deformations. The observed concrete compression of the instrumented test piles is also shown in Table 3.2 for comparison. 


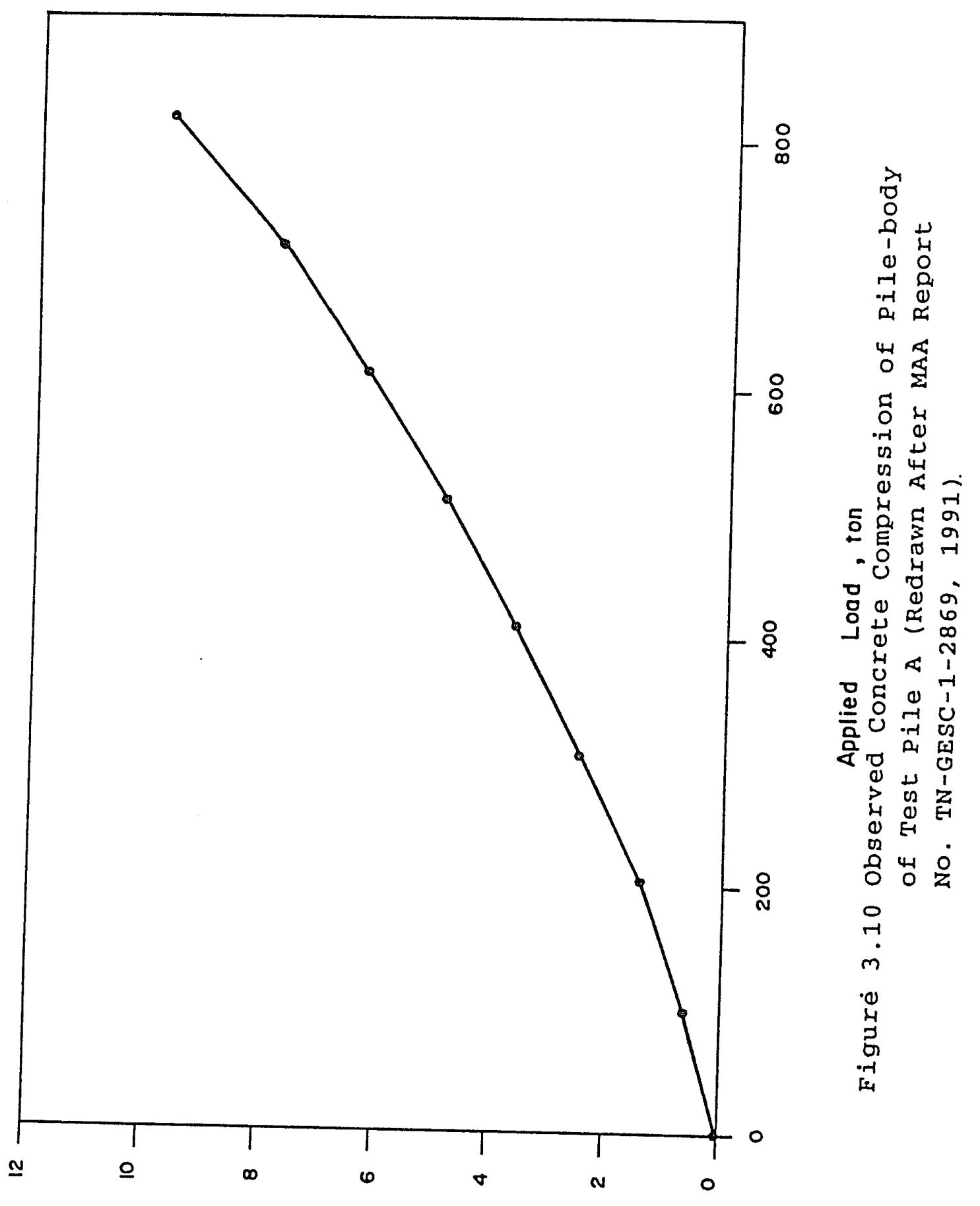

mu ' volssajdmoz kpoq- ग! 


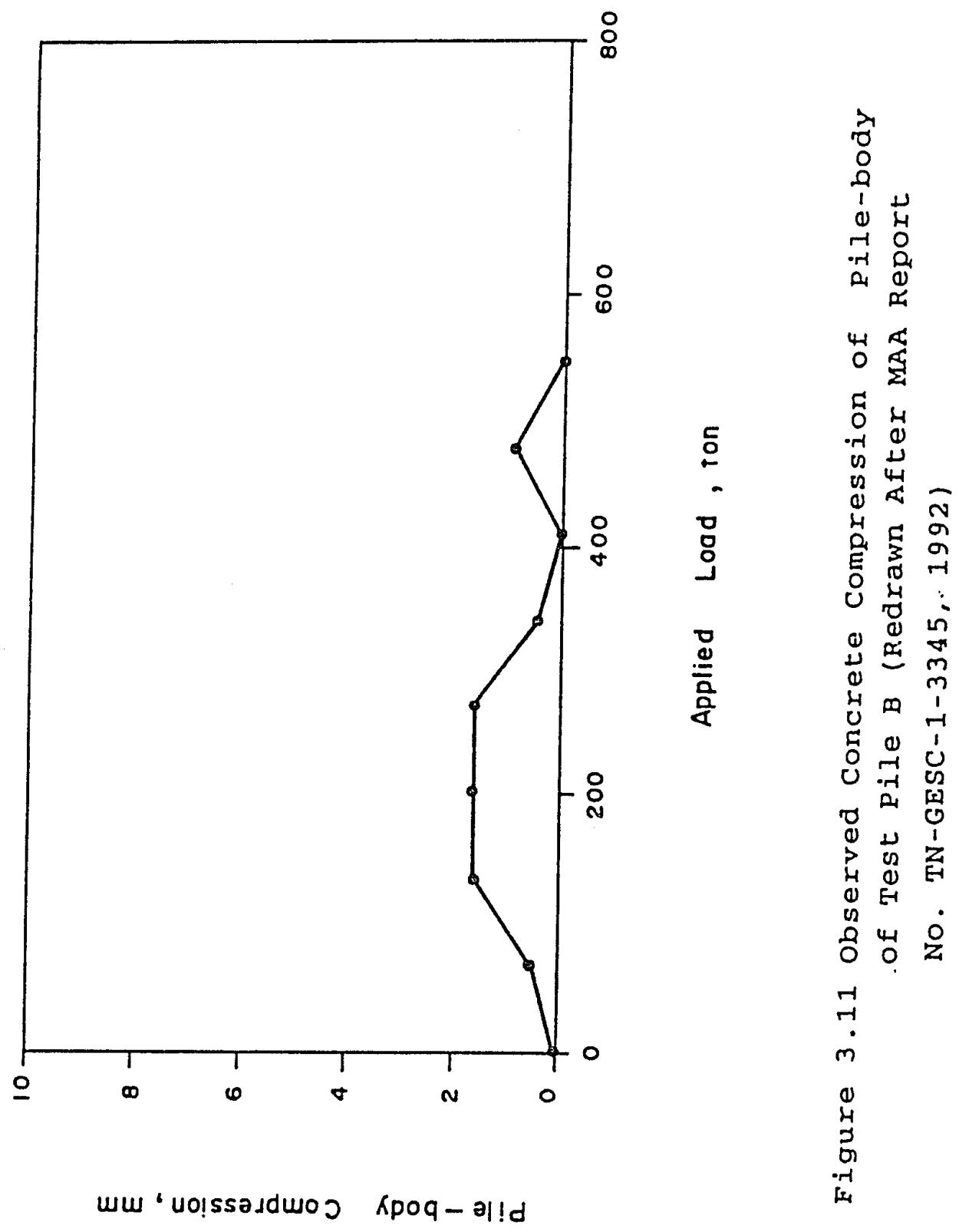




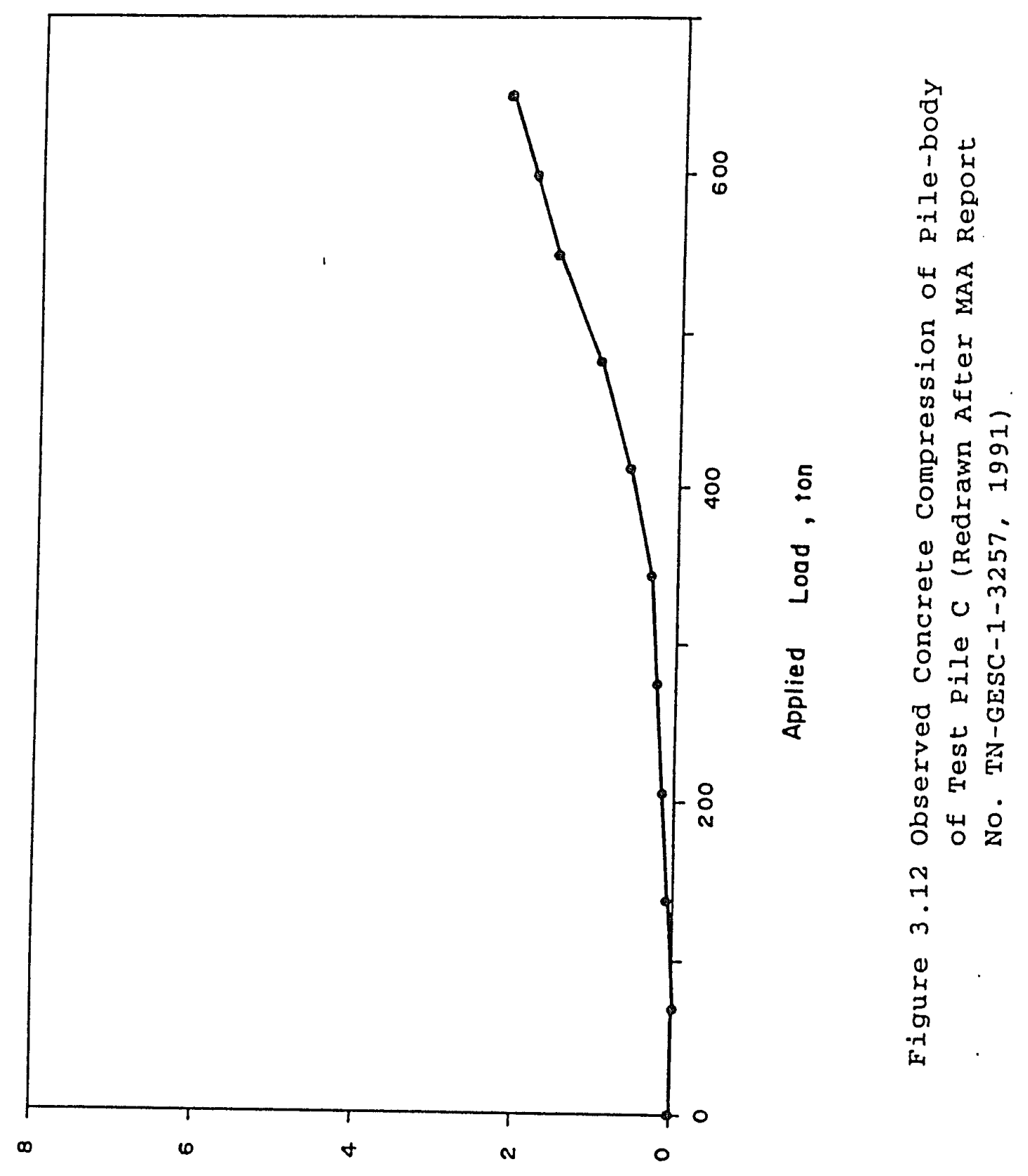

mus 'volssajdmos kpoq-al!d 


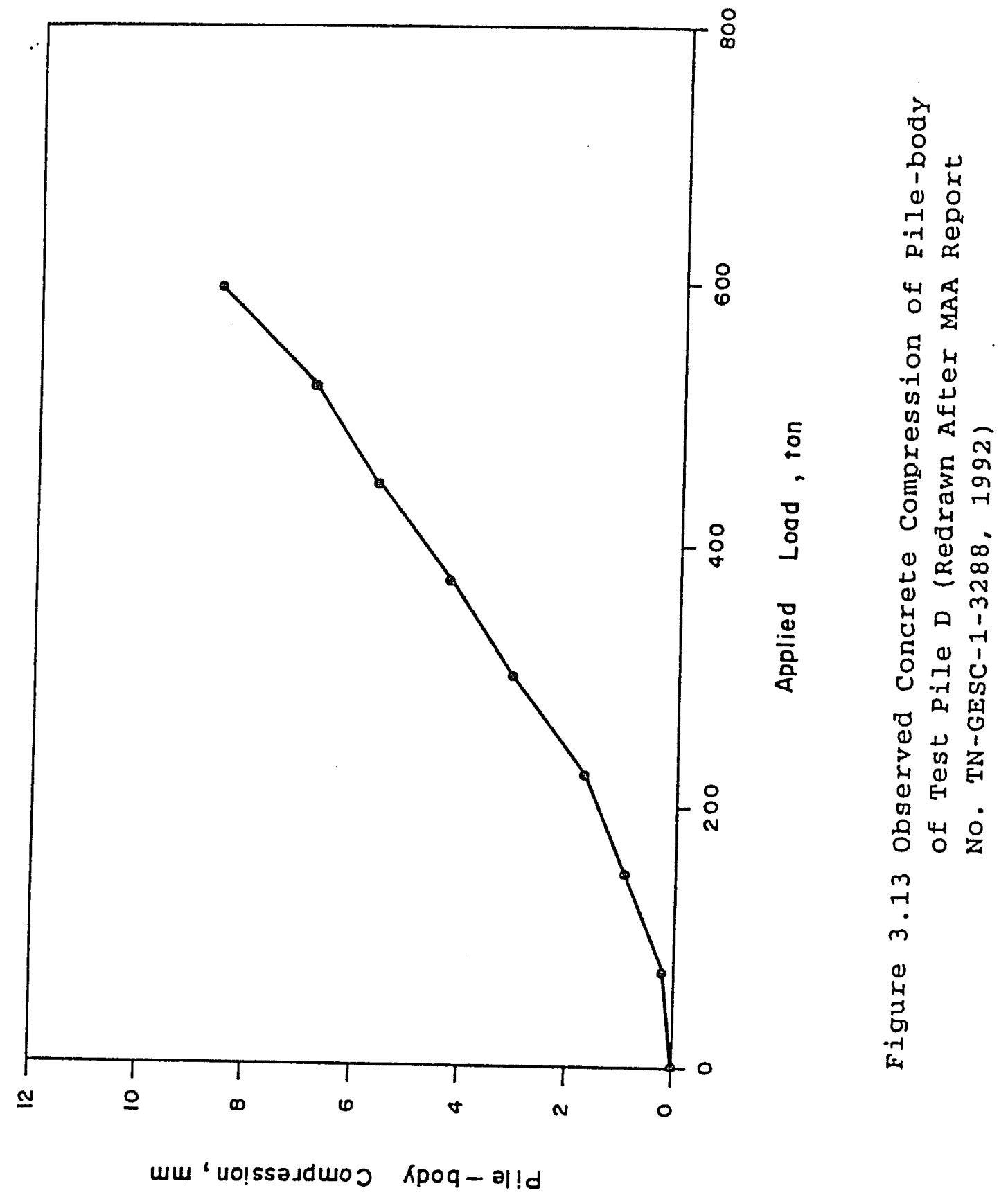




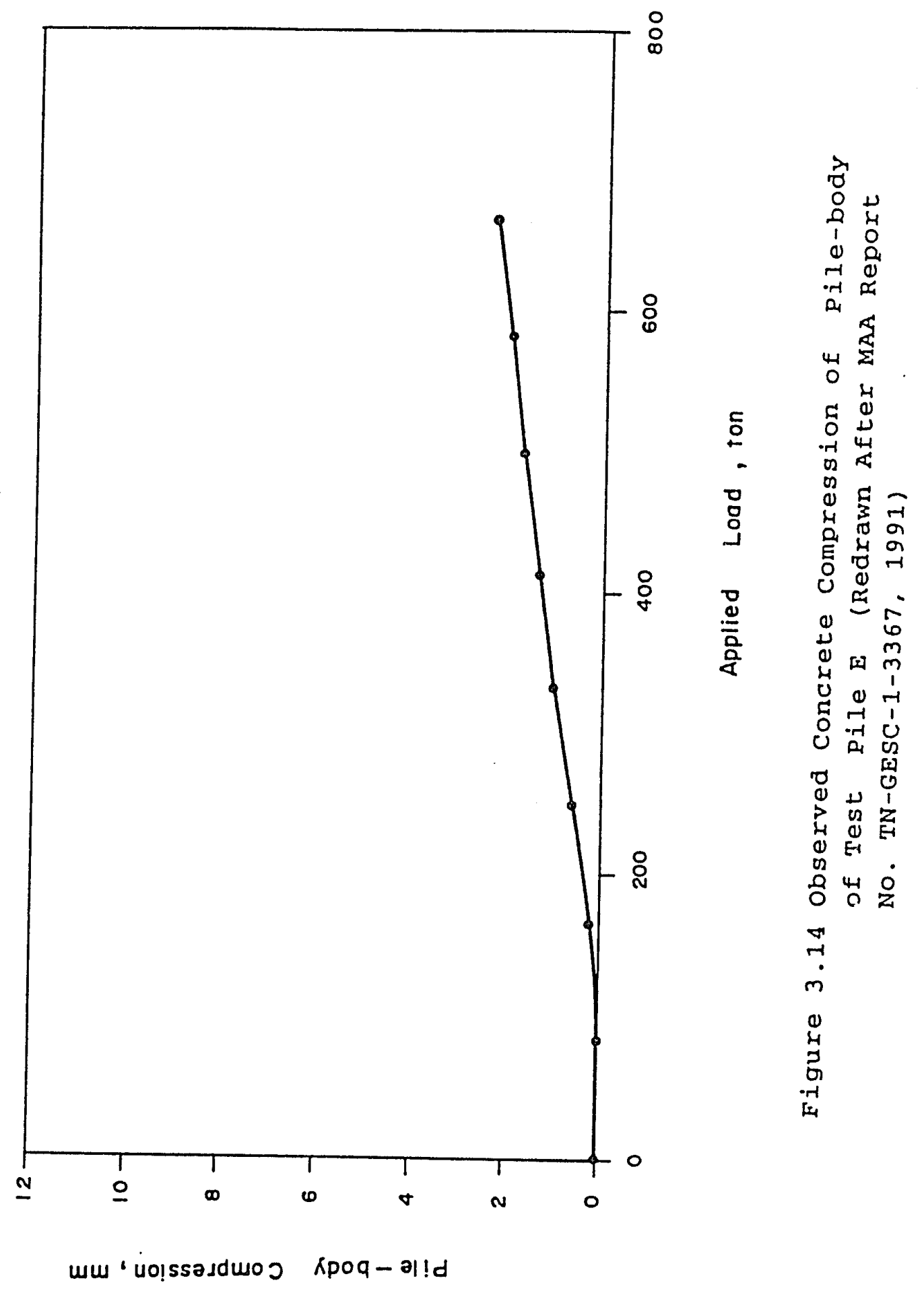




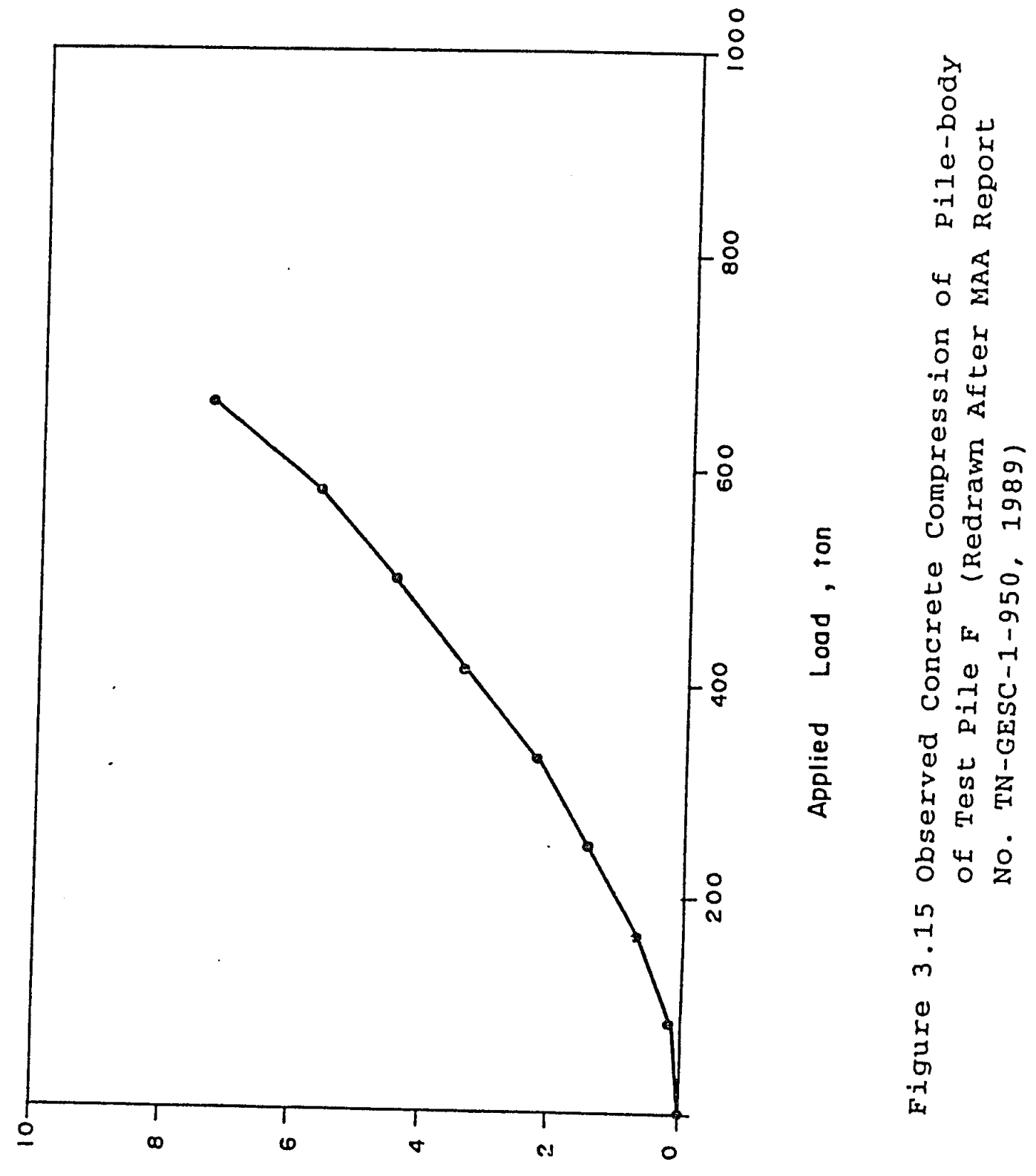

uس 'vo!ssajduos кpoq-әा!d 
As can be seen in Table 3.2, the observed concrete compressions of piles $A, D$ and $F$ are approximately equal to the computed elastic deformations, indicating that a good contact between bottom of the pile (i.e., load cell body) and tip bearing layer was gained by cement grouting at the pile tip executed prior pile concreting as described above. While for piles $E$ and $B$, although the same grouting measures had been taken, the effectiveness was not gained. Their observed concrete compressions are nearly the same amount as that of pile C, which was constructed following the common procedure of reverse circulation drilling technique mostly used in Taiwan (as described in Chapter 4).

MAA (1992) summarized the above-mentioned six instrumented test piles data and reported that the limiting shaft friction in cohesive soil layers developed at relative slip or displacement between pile and soil on the order of 4 to $5 \mathrm{~mm}$, as shown in Figure 3.16 .

\subsection{The Applied Interpretive Technique and Assumptions}

Based on the above-mentioned information and data, it is hence assumed that for cast-in-place bored piles constructed with the reverse circulation drilling technique, the unavoidable loosening of the base of the bore and the uncleaned slime at the 


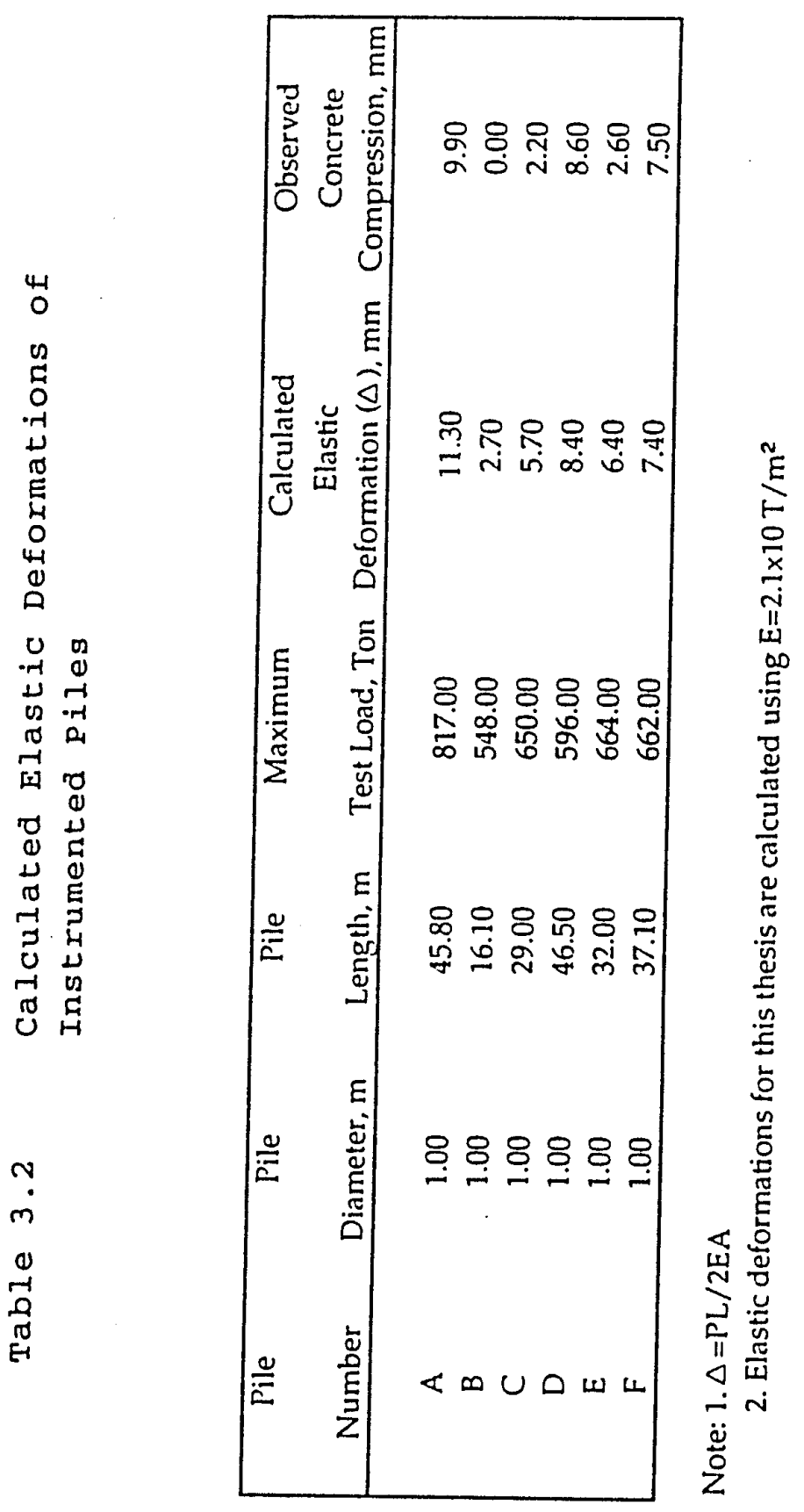


bottom of bored holes make the butt and base settlement, at the initial loading stage where loading is resisted mostly by the shaft resistance, nearly equal.

In this thesis, the amount of butt settlement required to develop maximum shaft resistance is thus assumed to be $7.0 \mathrm{~mm}$ (which is the sum of $4.5 \mathrm{~mm}$, a value of slip between pile and soil required to develop maximum shaft friction, and $2.5 \mathrm{~mm}$, an observed value of concrete compression of the pile-body when constructed with the reverse circulation drilling technique), which is the same value as that reported by woo and Moh (1990). The observed maximum shaft resistance of test piles thus can be defined from the load versus butt settlement curve of each test pile, that is, the load at butt settlement is equal to $7.0 \mathrm{~mm}$.

The computations of shaft adhesion in cohesive soil are based on the two empirical approaches suggested both by Schmertmann (1978), and Tumay et. al. (1981), that the unit shaft friction of the pile, $f$, is a function of cone friction, fs, from Cone Penetration Test (CPT) data.

When granular soils are encountered, the relevant shaft friction is computed using the empirical formula suggested by Meyerhof (1976) as :

$$
f\left(T / m^{2}\right)=0.1 \mathrm{~N}
$$



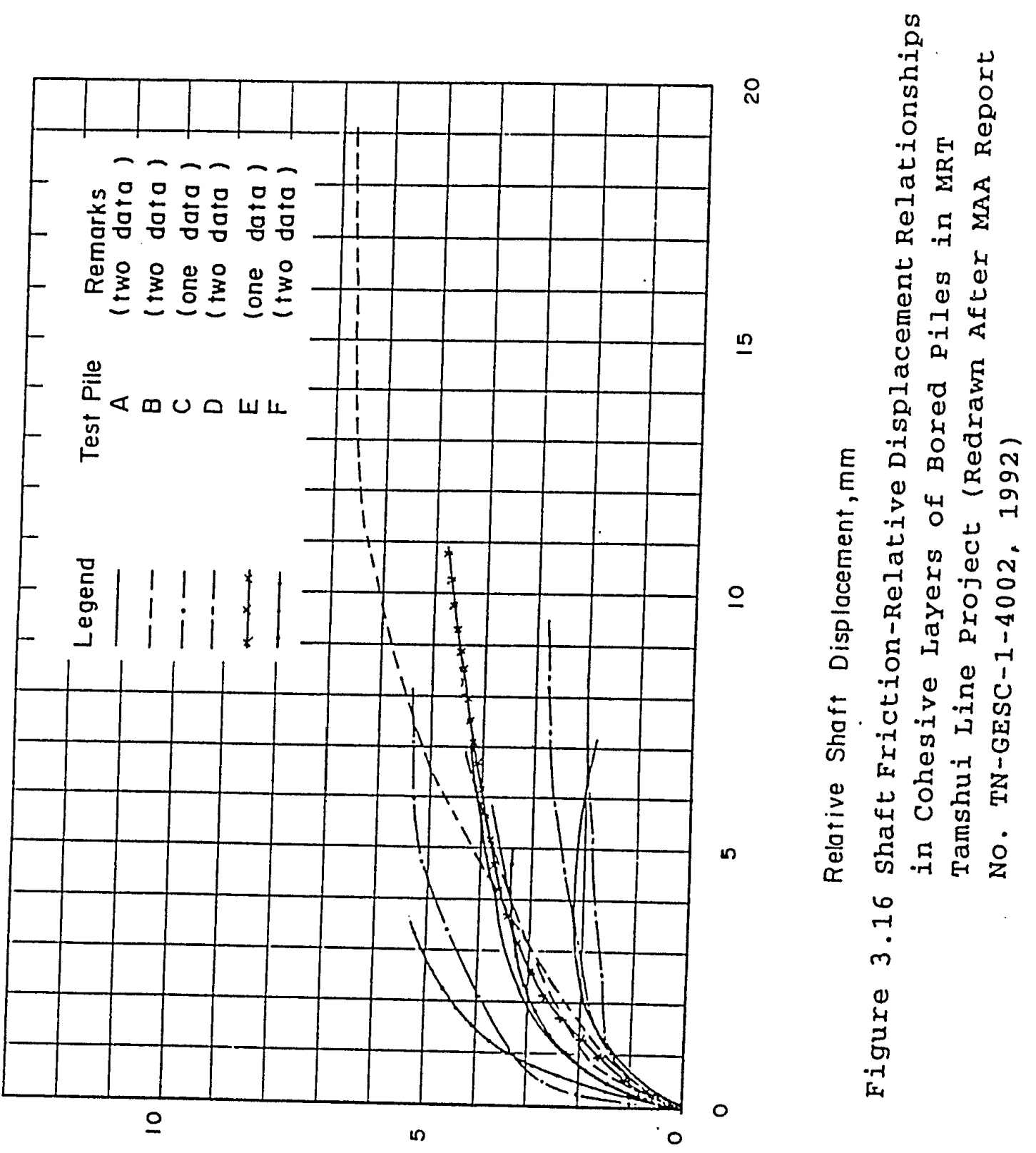

zW/1'vo!to!dy thous t!un 
where $\mathrm{N}=$
$\quad$ average value of Standard Penetration

Test resistance

The limiting value for shaft friction in granular soils of $12 \mathrm{~T} / \mathrm{m}^{2}$, usually used by Dutch engineers, (Schmertmann, 1978) is applied in this thesis. 


\section{CHAPTER IV}

CASE STUDIES

\subsection{General}

The gravel or rock-debris layer, with Standard Penetration Test's N-values larger than 100 in Taipei, has always been used as the bearing stratum for the bored piles. Because of the relatively deep depth of the gravel or rock-debris layer from the ground surface, long piles with pile diameters ranging from 1.0 to $2.0 \mathrm{~m}$ are commonly used. In normal cases, a pile is designed to take both skin friction and end bearing.

The pile load tests referred to in this thesis are those normally carried out on a cast-in-situ bored pile by the application of loading at the top of the pile with settlements at the pile top being observed as the loading is progressively increased to the full value of the test load, and also as the pile is being unloaded. 


\subsection{Geological and Soil Conditions}

\subsubsection{General Geological setting}

Taiwan is an island $180 \mathrm{~km}$ off the coast of the Chinese Mainland, separated by the Taiwan straits. The island comprises about 36,800 square kilometers.

The Taipei Basin is located at the northern corner of the

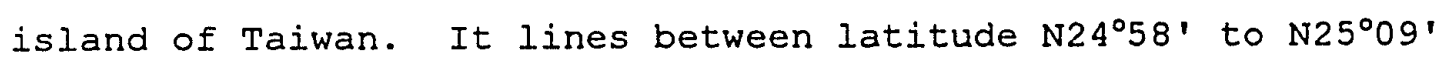
and longitude $\mathrm{E} 12^{\circ} 25^{\prime}$ to $\mathrm{E} 12^{\circ} 37^{\prime}$, occupying a total area of 243 square kilometers and with a general elevation of 9 meters above sea level (Huang, 1962). The Basin is geographically bounded by three major rivers: the Keelung River, the Tahan River and the Hsintien River as shown in Figure 4.1. Surrounding the Basin is the Tatun Volcanic Group on the North, the Linkou Tableland on the West and foothills on the East and the South.

Geologically speaking, the Taipei Basin is a tectonic basin, formed between the Pliocene and Pleistocene Age ( about two to three million years ago), covered with Quaternary sedimentary deposits overlying the Tertiary bedrock. The thickness of the sedimentary deposits is estimated, ranging from 10 meters to 240 meters, and can be divided into three formations. They are, in the order of older to younger lor from deeper to shallower): the Hsinchuang Formation (consisting of alternative layers of yellow or gray sandy clay and gravel), the 


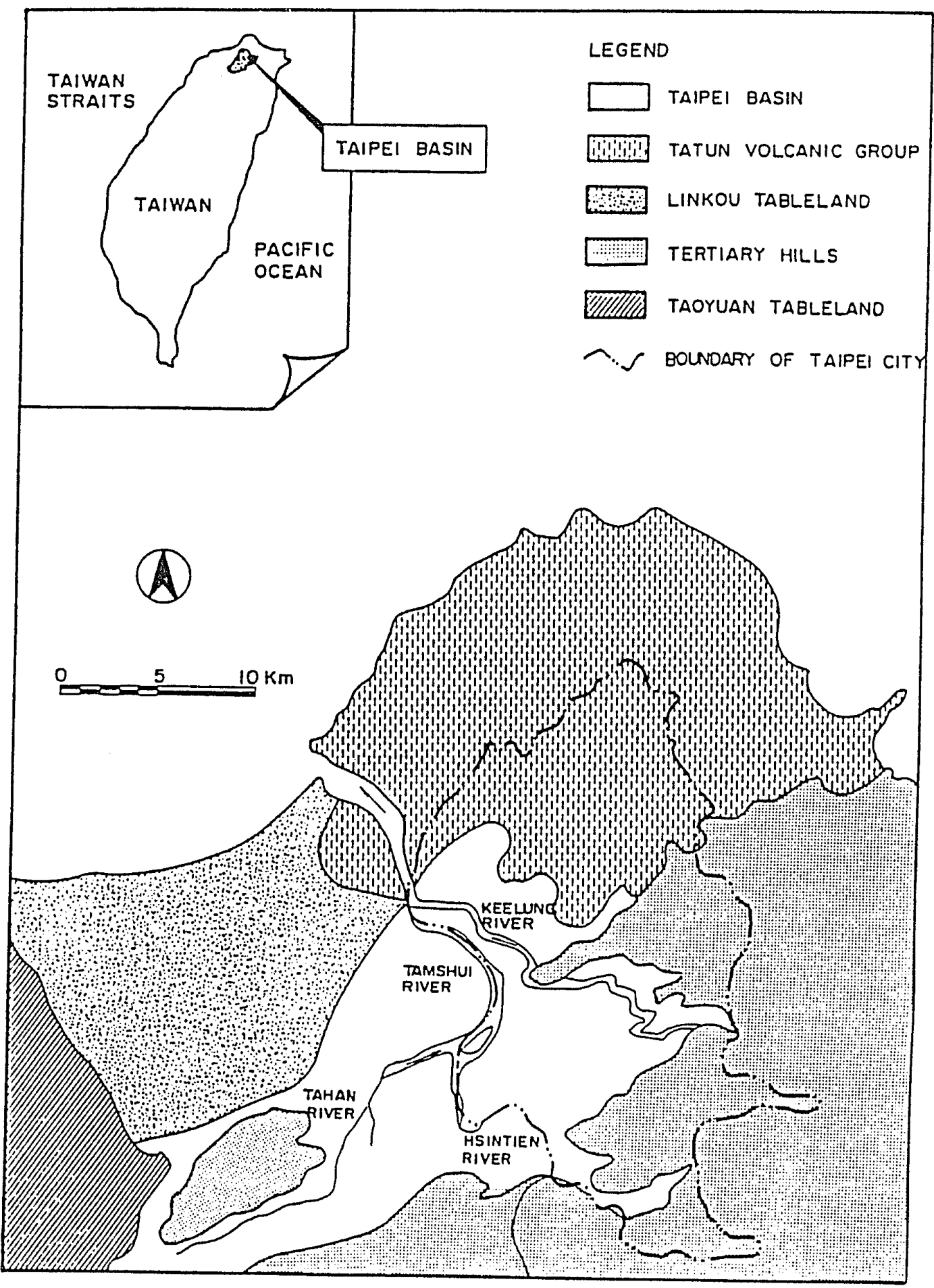

Figure 4.1 Geological conditions of the Taipei Basin and It's surrounding Areas 
Chingmei Formation (basically a gravel layer with large amount of coarse sand) and the Sungshan Formation (consisting of alternating layers of silty clay and silts interstratified with fine sand layers containing a high silt content) (Woo and Moh, 1990)

The Sungshan Formation, which is immediately below the ground surface and extends to a depth of about 10 to 60 meters, is most significant to the underground constructions and foundations in the Basin region.

On the basis of the geological origin and sedimentary environment, the Sungshan Formation within the eastern area of the Basin was divided into three major zones according to the tributary of the rivers as shown in Eigure 4.2, namely: Tamshui River zone, Hsintien River zone and Keelung River Zone (Hung, 1966). The sediments of the Tamshui River tributary area have the typical characteristics of the sungshan Formation, recognized by most, and found in the downtown area of Taipei, that is alternating layers of fine sand and silt / clay. The sediments along the tributary area of the Hsintien River are predominately of sands, silty sands and sandy gravels. Whereas the basin sediments along the tributary area of the Keelung River are predominately of fine grained silts and clays. The pile load tests referred to in this thesis are all located within the tributary area of the Keelung River. 


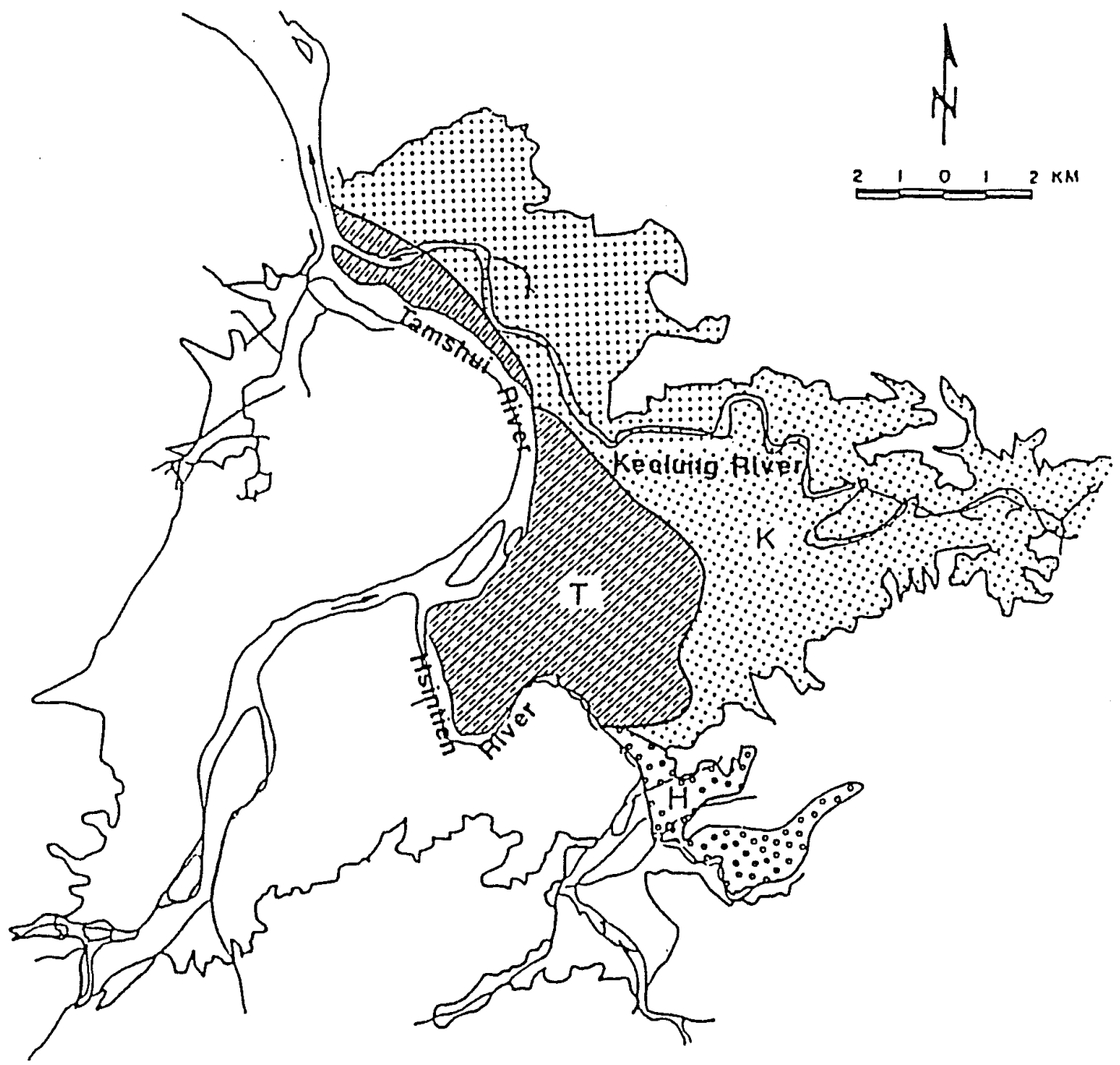

Note:

T: Tamshui River Zone .

$\mathrm{H}$ : Hsintien River Zone .

$\mathrm{K}$ : Keelung River Zone.

Figure 4.2 Location of Major zones of Sungshan Formation 


\subsubsection{Soil Condition}

A total number of eighteen piles are considered in this thesis as shown in Eigure 4.3. All of them are located within the tributary area of the Keelung River, i.e., predominately consisting of fine grained silts and clays. The soil conditions for each location of test piles are as shown in Figures 4.4 through 4.21, with soil type abbreviations as shown in Table 3.1. The boreholes with Standard Penetration Test were performed within 10 meters from each test pile location, while the locations of Cone Penetration Tests (CPT) were within 50 meters from each test pile.

The soil parameters for each test pile, as shown in Figures 4.4 through 4.21 , are based on the nearest reference boreholes and CPT data from each test pile, and are also based on the construction records of each test pile. 


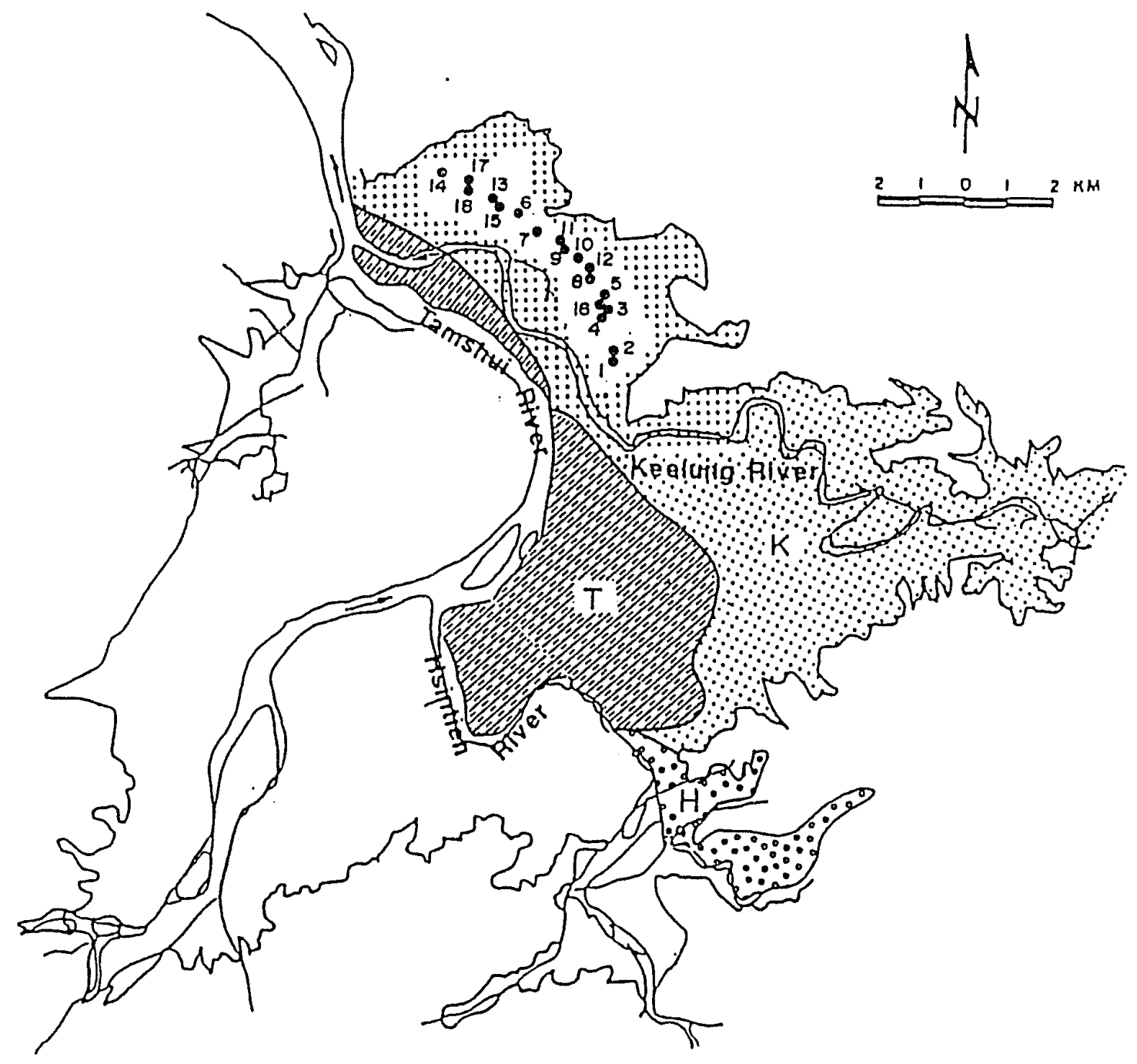

Nole:

T: Tomshui River Zone .

$H$ : Hsintien River Zone.

$\mathrm{K}$ : Keelung River Zone.

$0: 1 \sim 18$ Test Ples.

Figure 4.3 Location of Test piles 


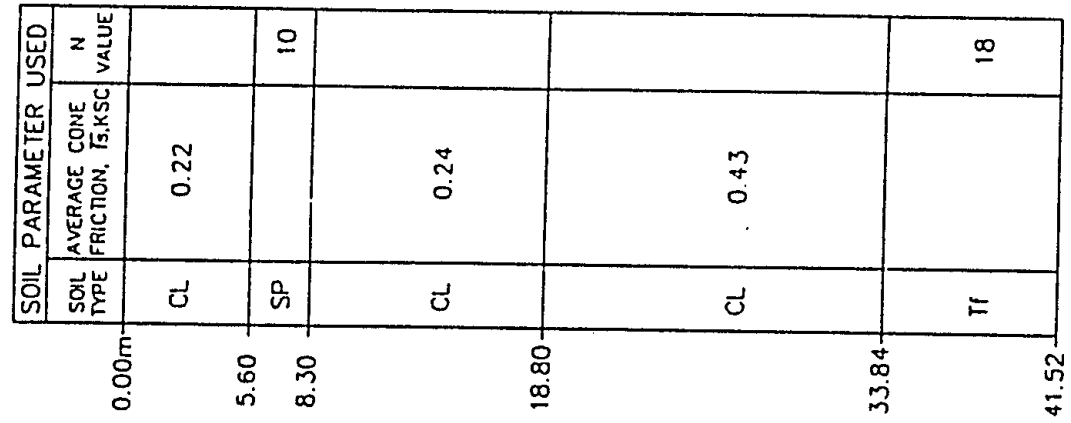
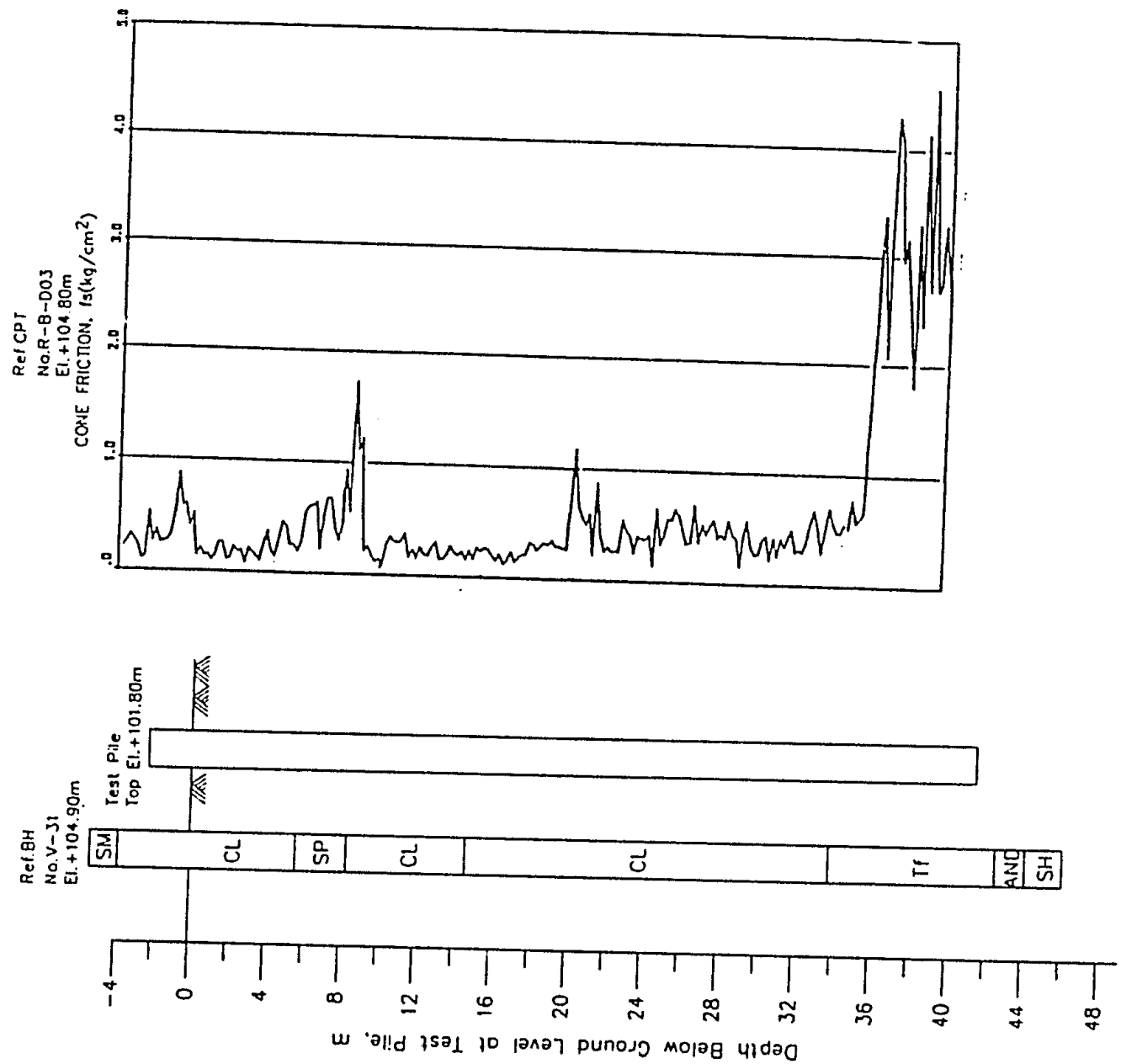

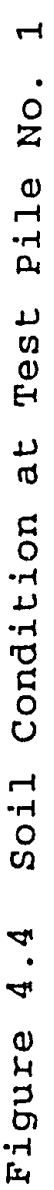




\begin{tabular}{|c|c|c|c|c|c|c|}
\hline 怘 & $\mathrm{z}$ & & 으 & & & \\
\hline 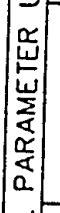 & 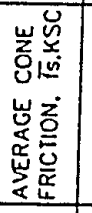 & $\stackrel{\infty}{0}$ & & ్ㅠㅁ & $\begin{array}{l}\mathscr{\varphi} \\
\dot{0}\end{array}$ & 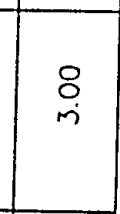 \\
\hline \begin{tabular}{|l|} 
\\
임 \\
\end{tabular} & 志㟧 & $\vec{\jmath}$ & is & $\vec{\jmath}$ & $\overrightarrow{0}$ & $\vec{U} \backslash \bar{\Sigma}$ \\
\hline & $\begin{array}{l}E \\
\stackrel{0}{0} \\
\stackrel{2}{0}\end{array}$ & & & & & $\frac{1}{10}$ \\
\hline
\end{tabular}
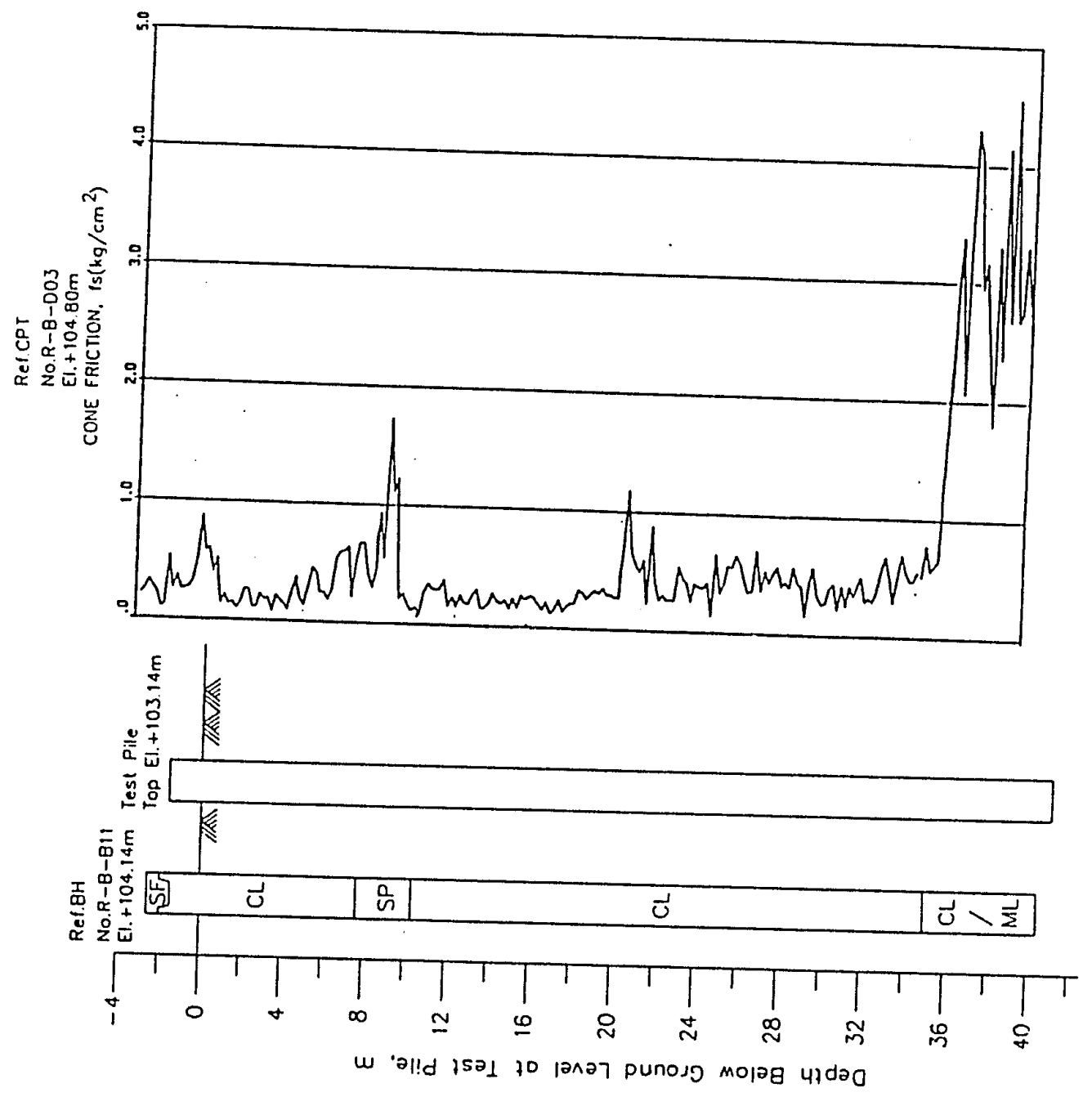

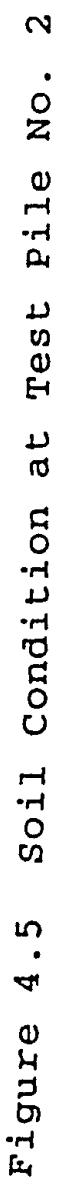



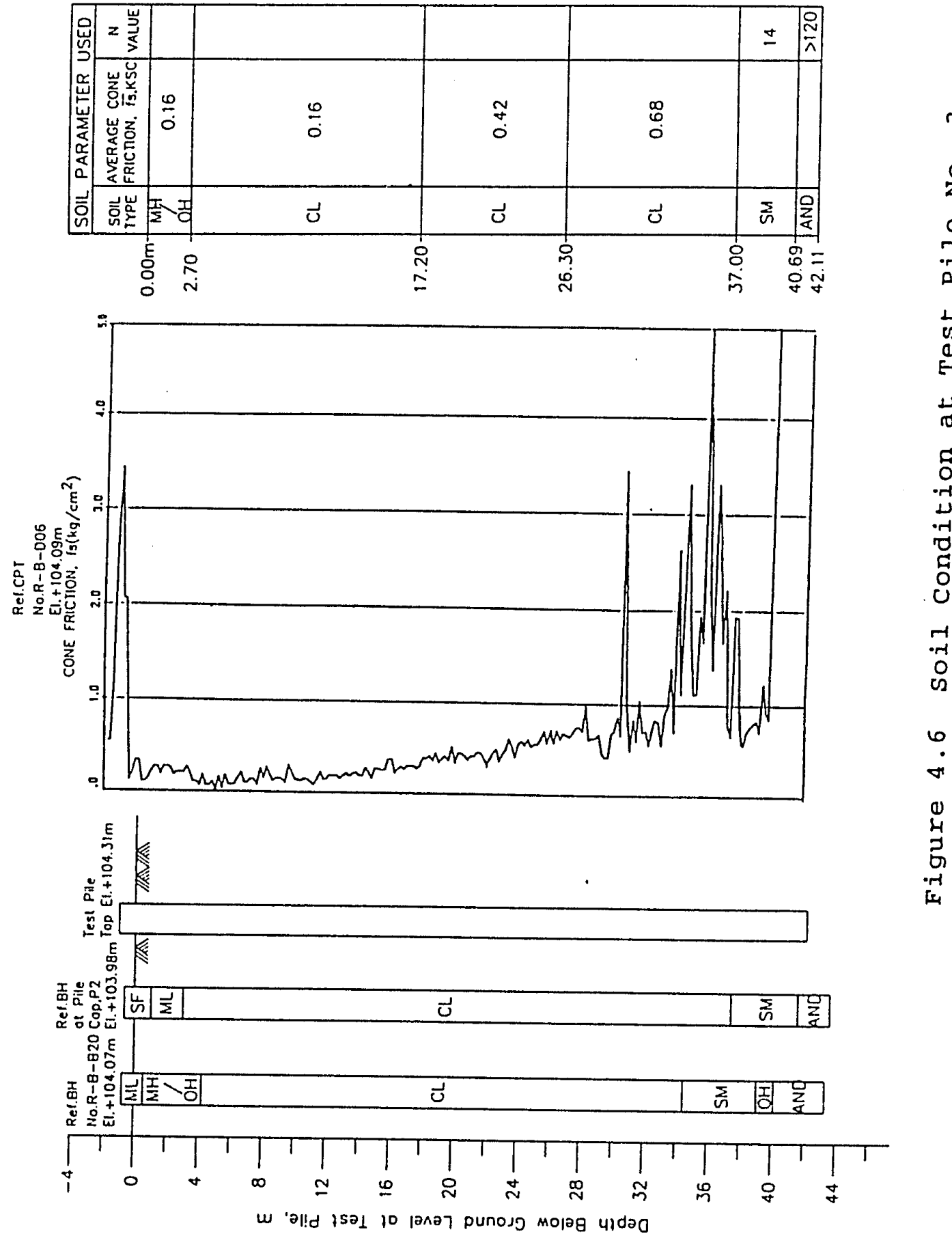


\begin{tabular}{|c|c|c|c|c|c|}
\hline 悹 & $=\stackrel{W}{3}$ & & & & $=\theta$ \\
\hline 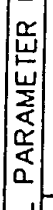 & 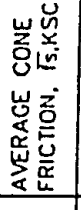 & $\stackrel{\circ}{\circ}$ & $\underset{\mathscr{Y}}{\tilde{0}}$ & $\begin{array}{l}\infty \\
0 \\
0 \\
0\end{array}$ & \\
\hline $\mid \begin{array}{l}\mid \\
\text { Dे } \\
\text { in }\end{array}$ & 棓㟧 & త & Ј & 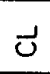 & 动展 \\
\hline & 0 & & & & ले ले \\
\hline
\end{tabular}

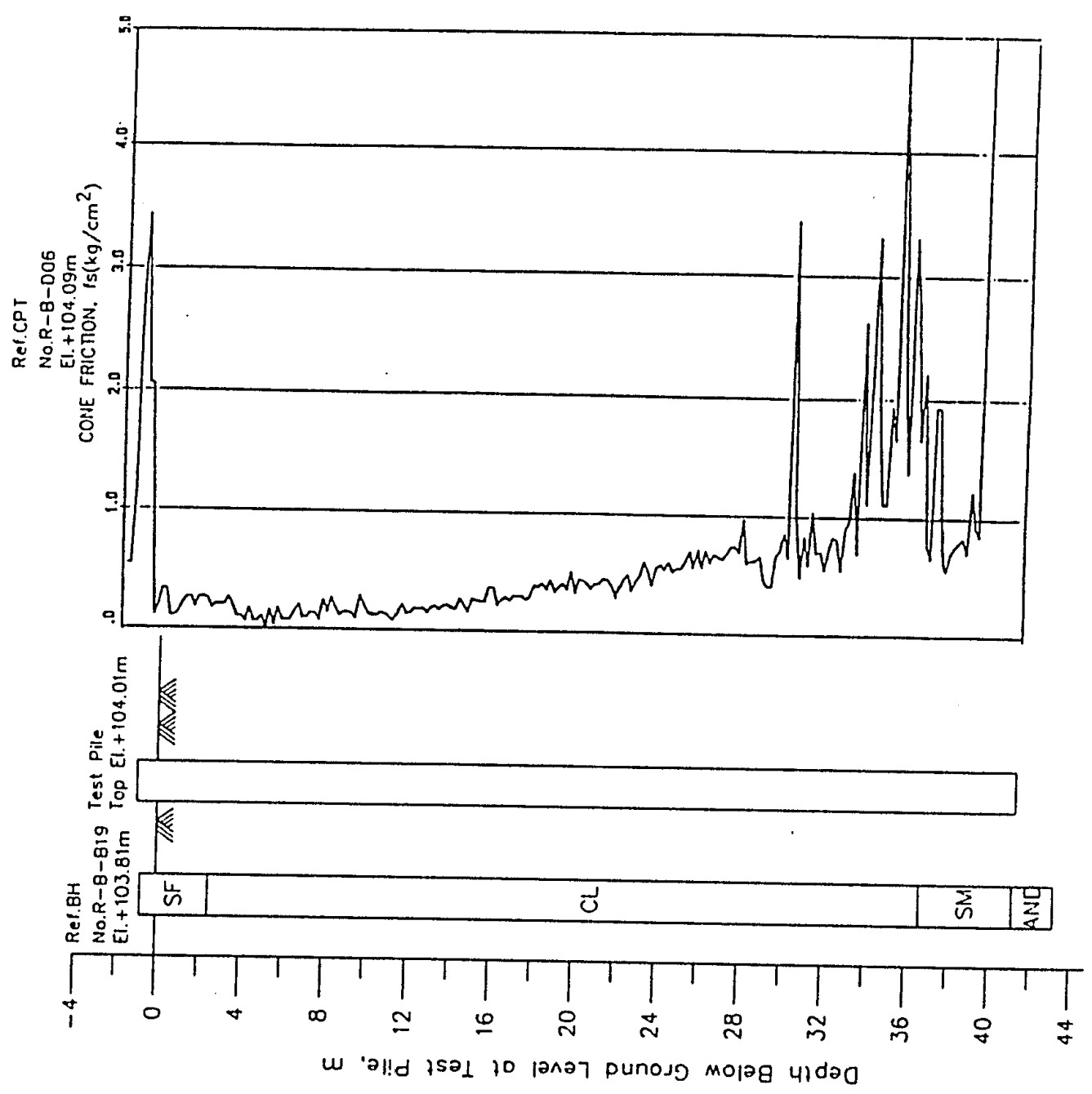

0 


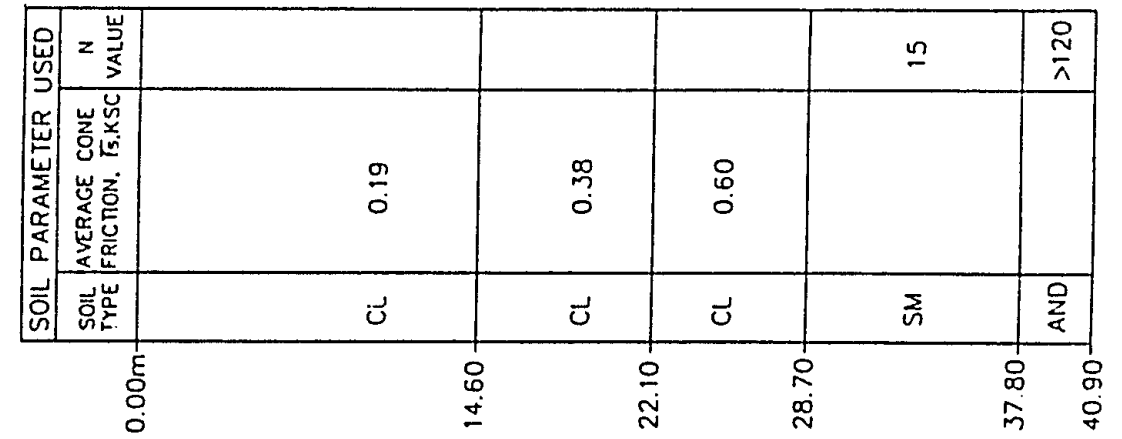

$n$
0
$z$
0
0
-1
-1
$a$
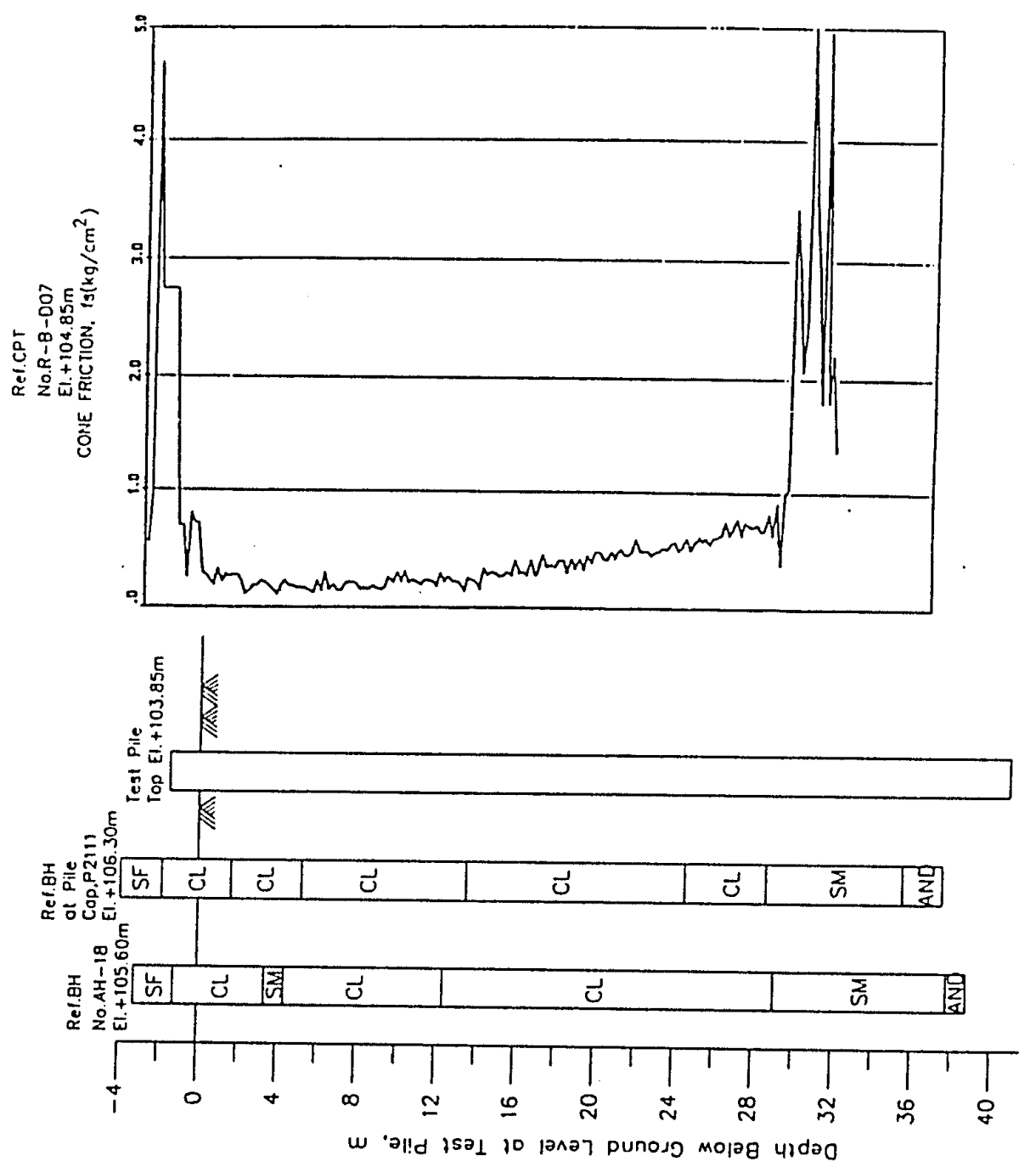

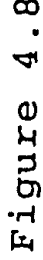




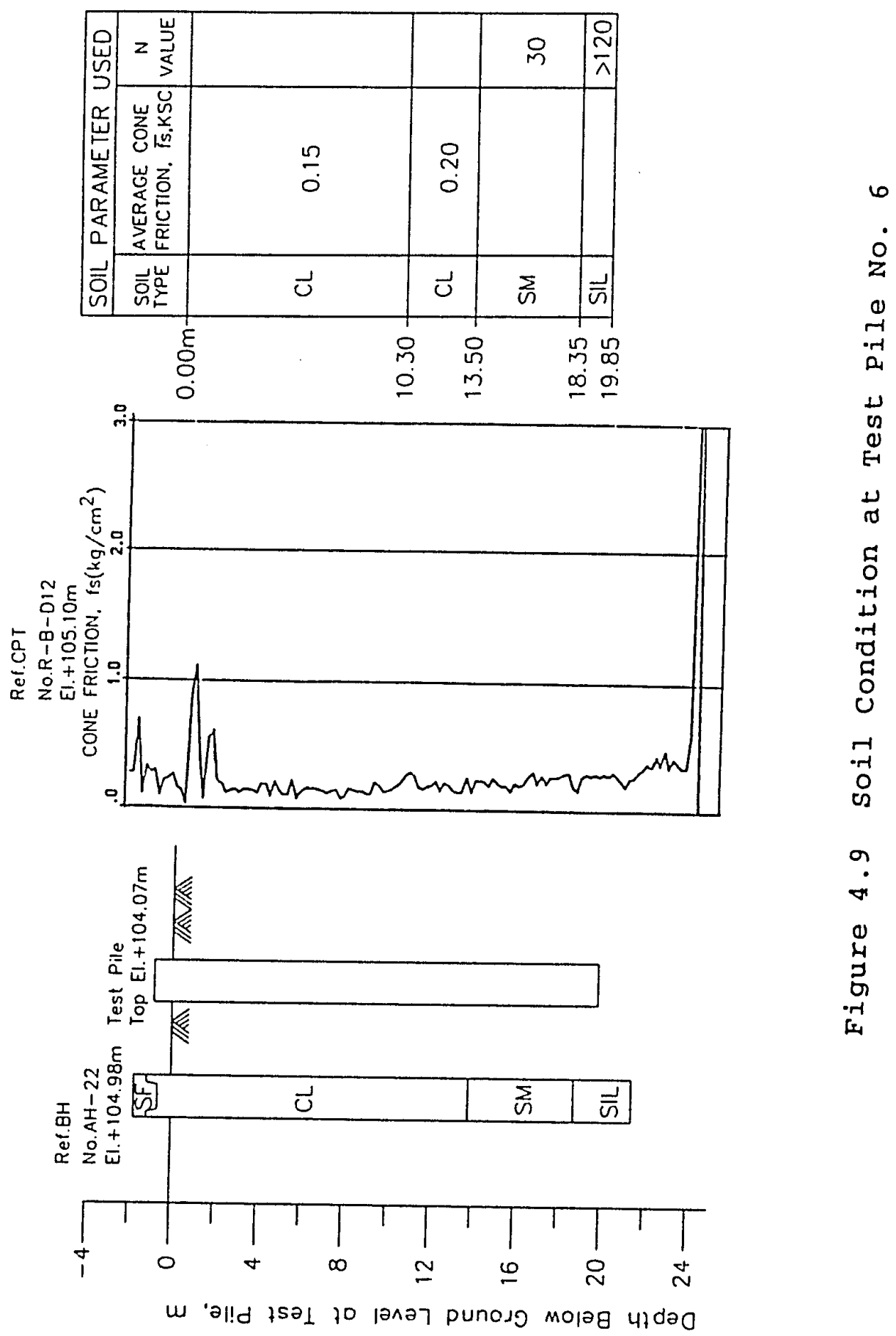



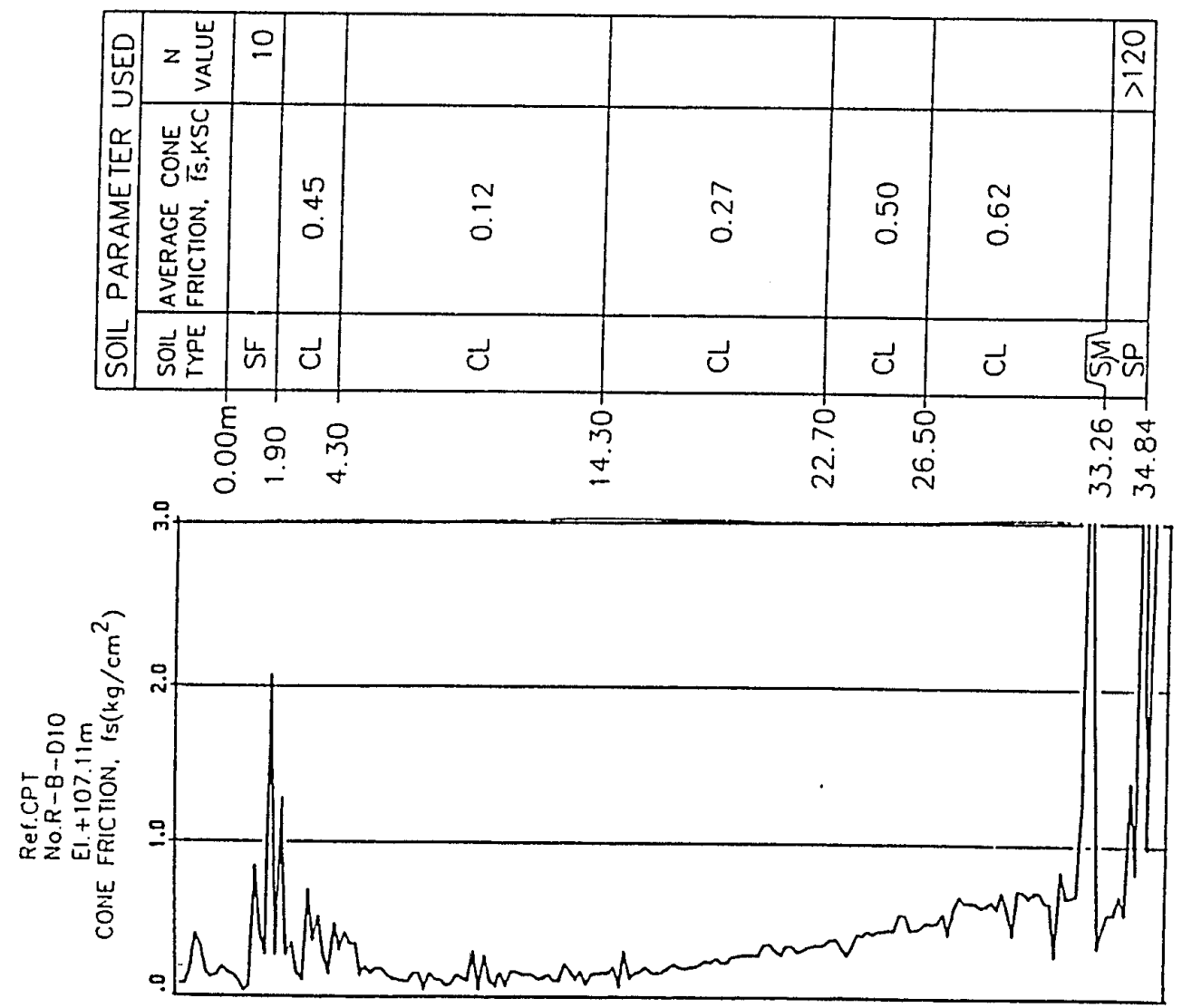

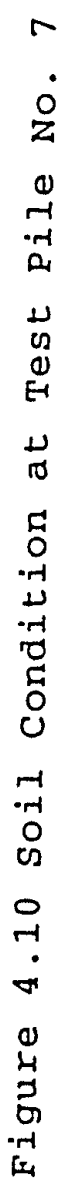

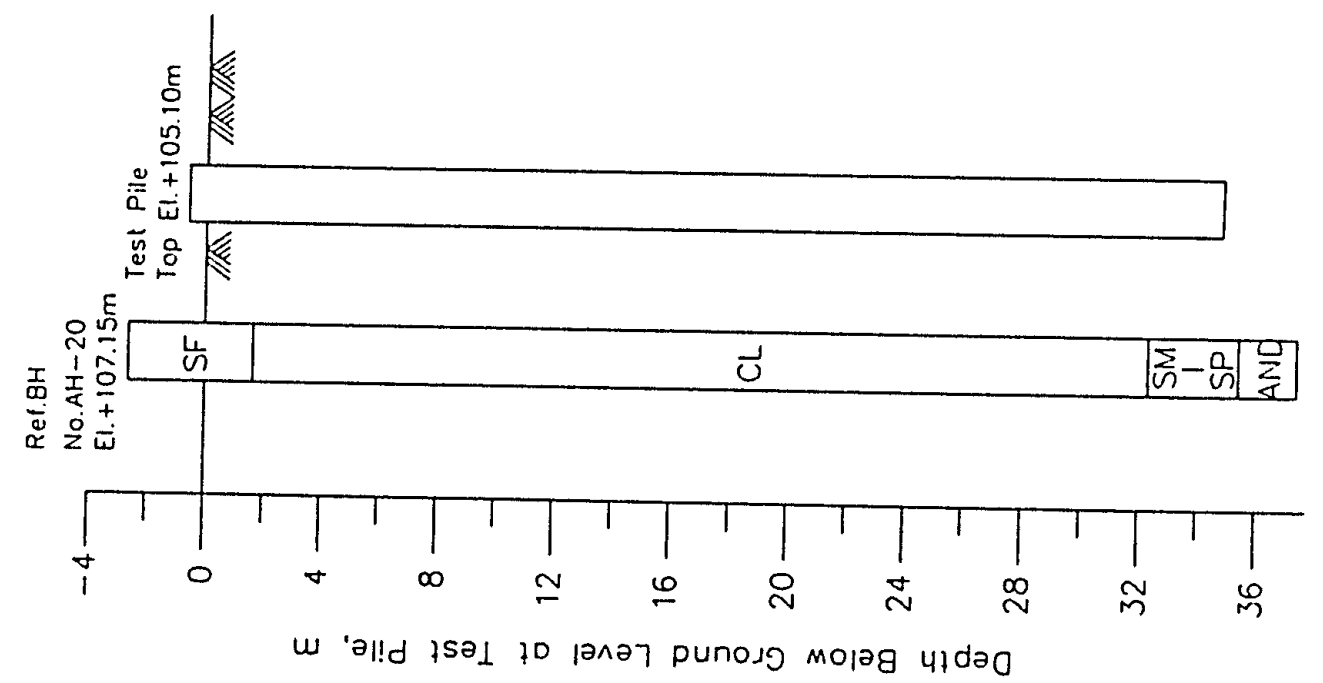



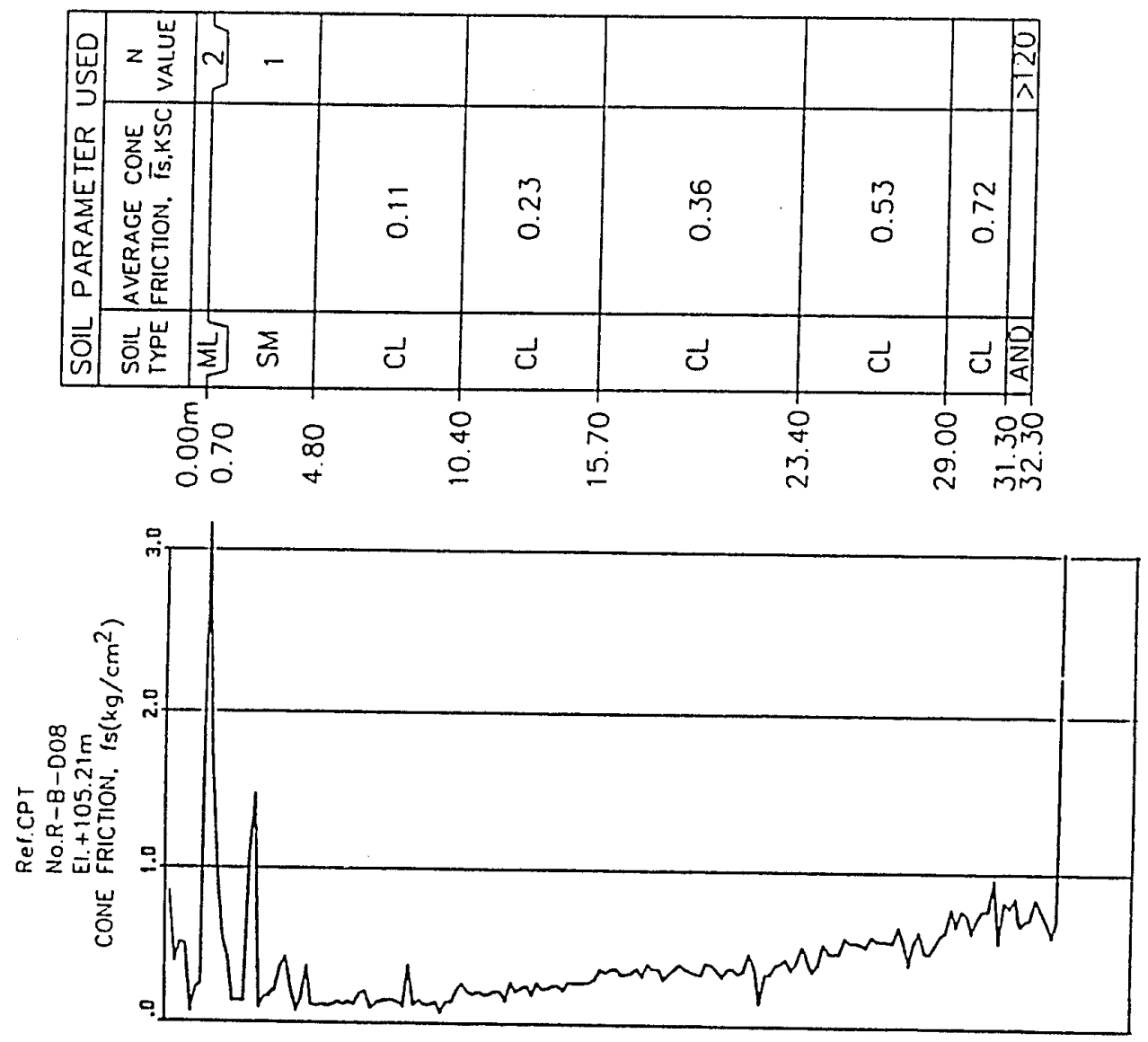

CO

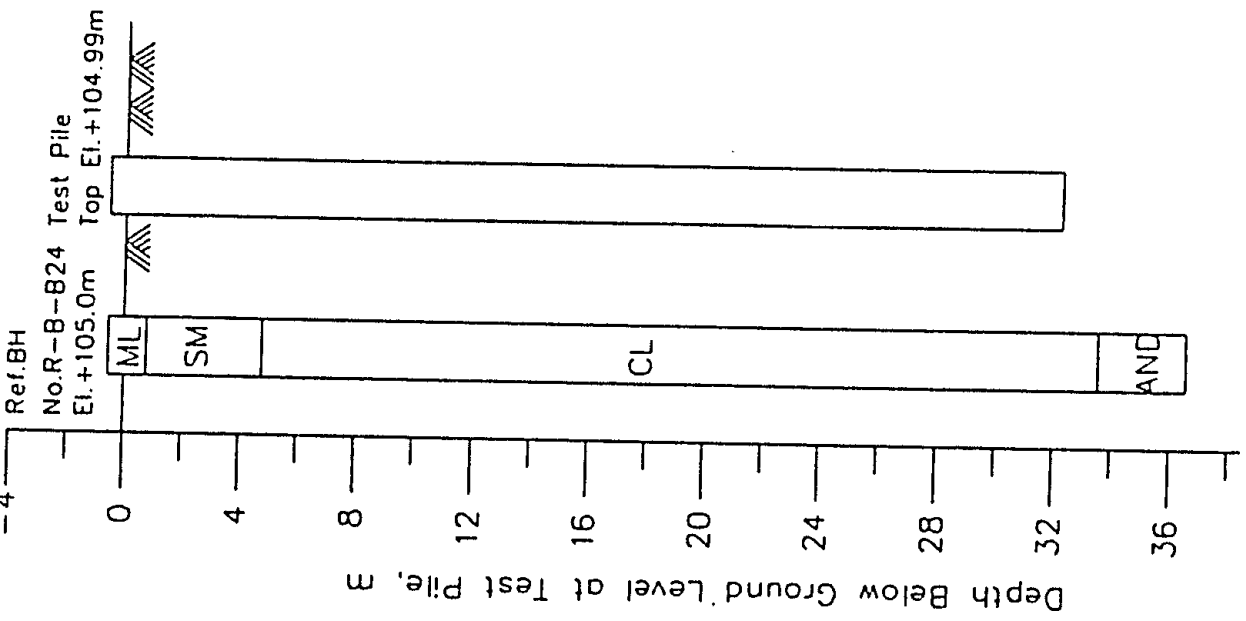




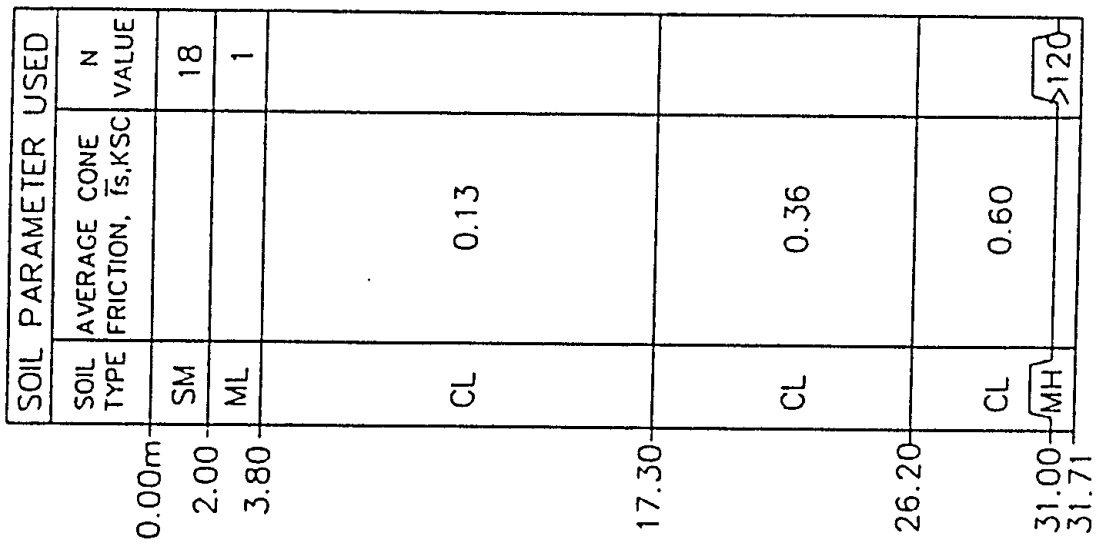

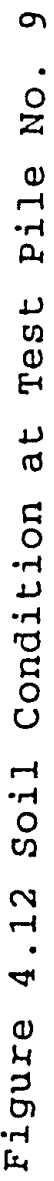

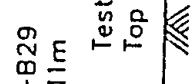
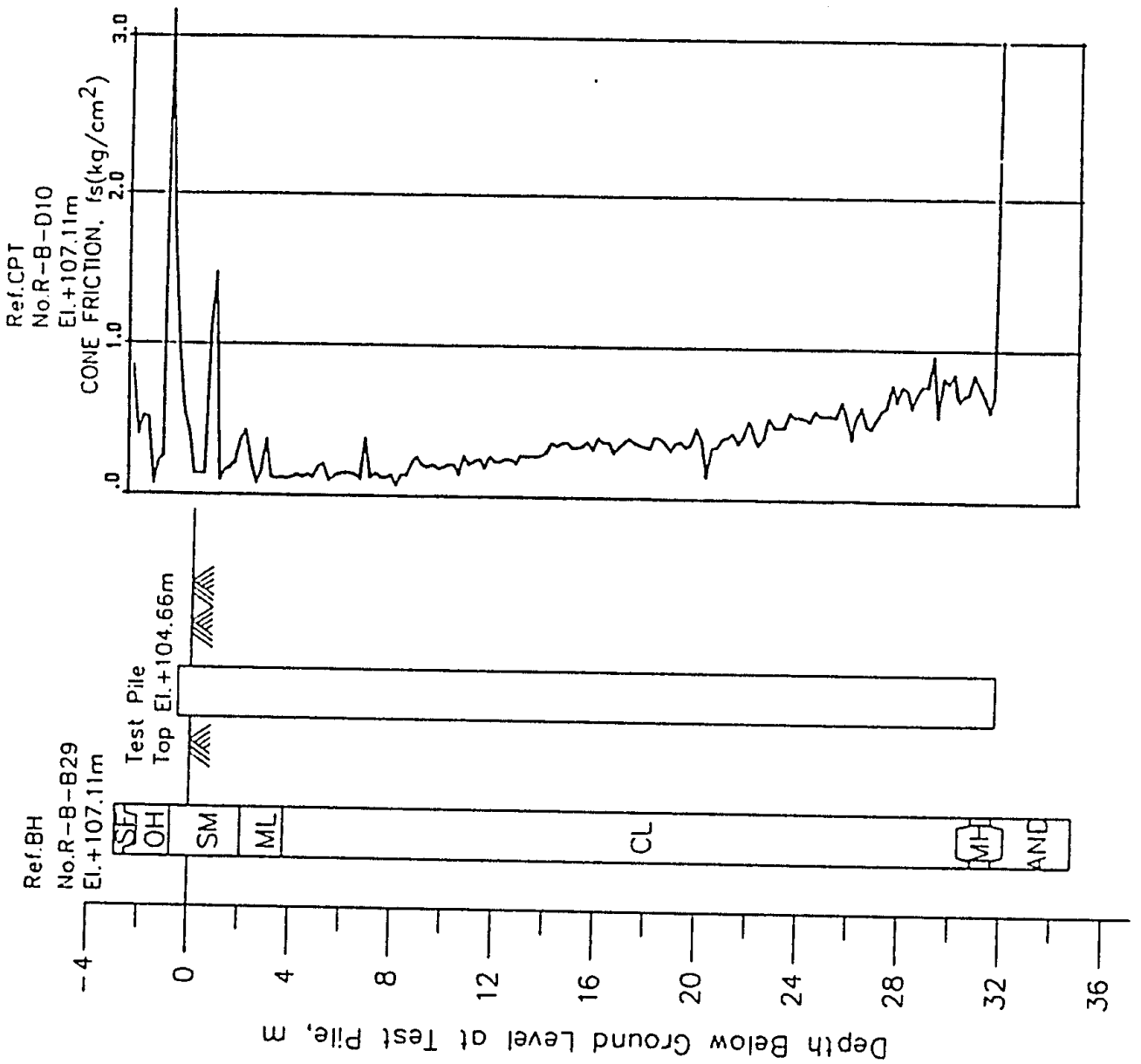

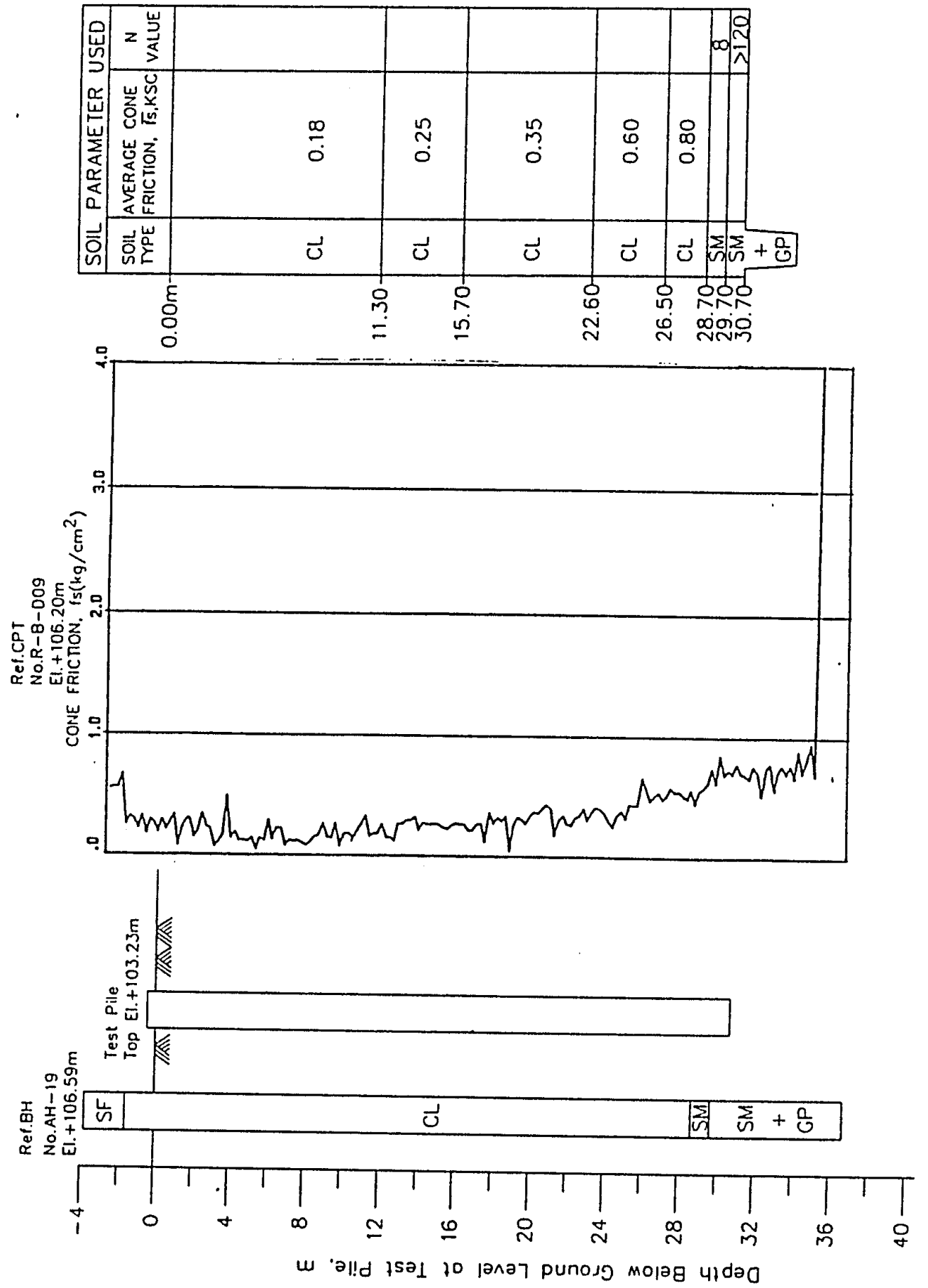

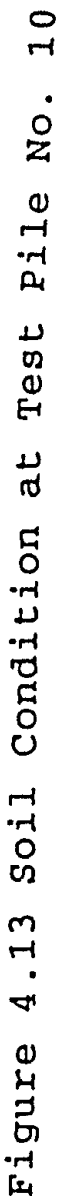



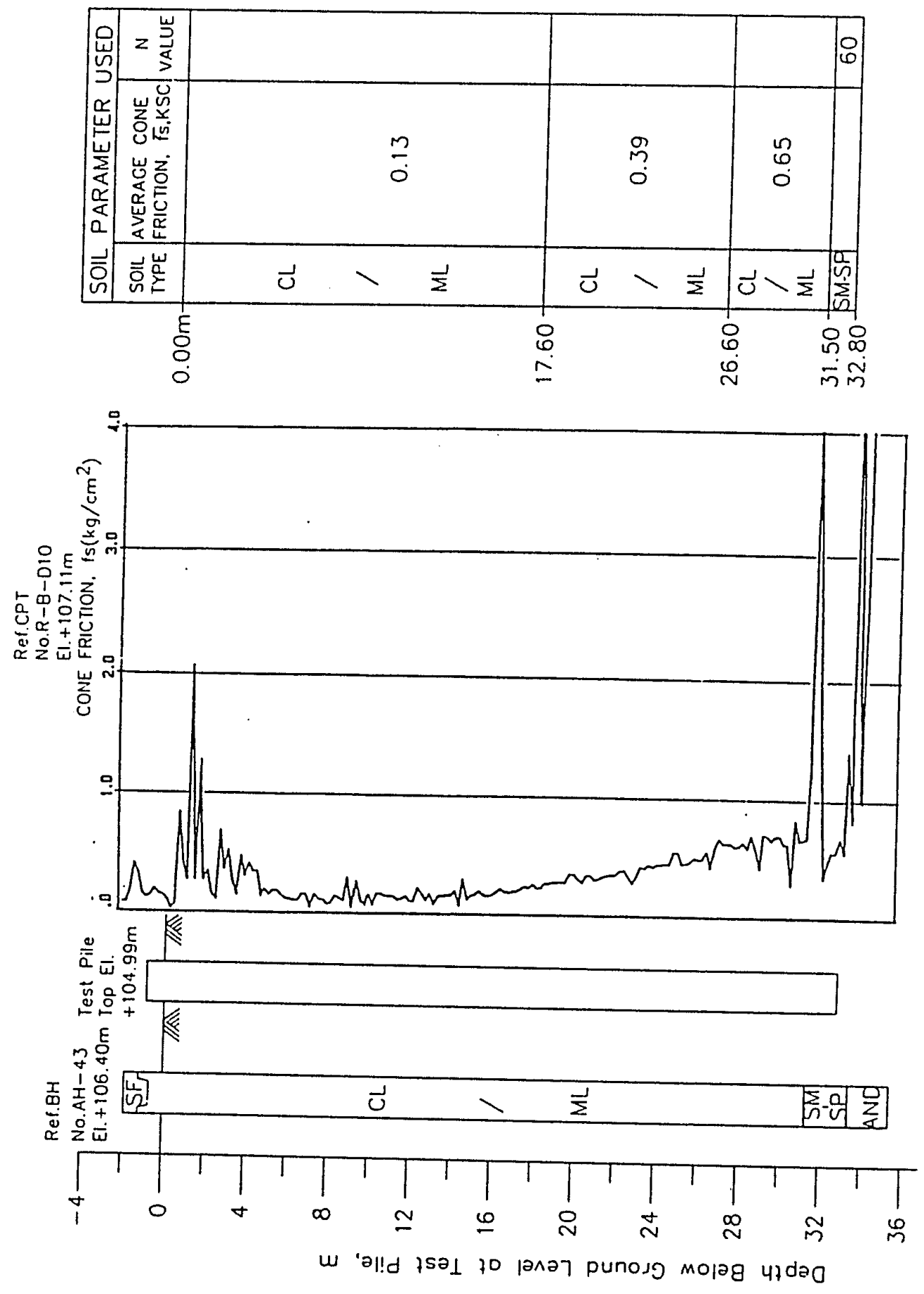

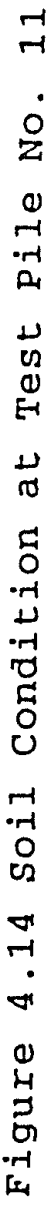



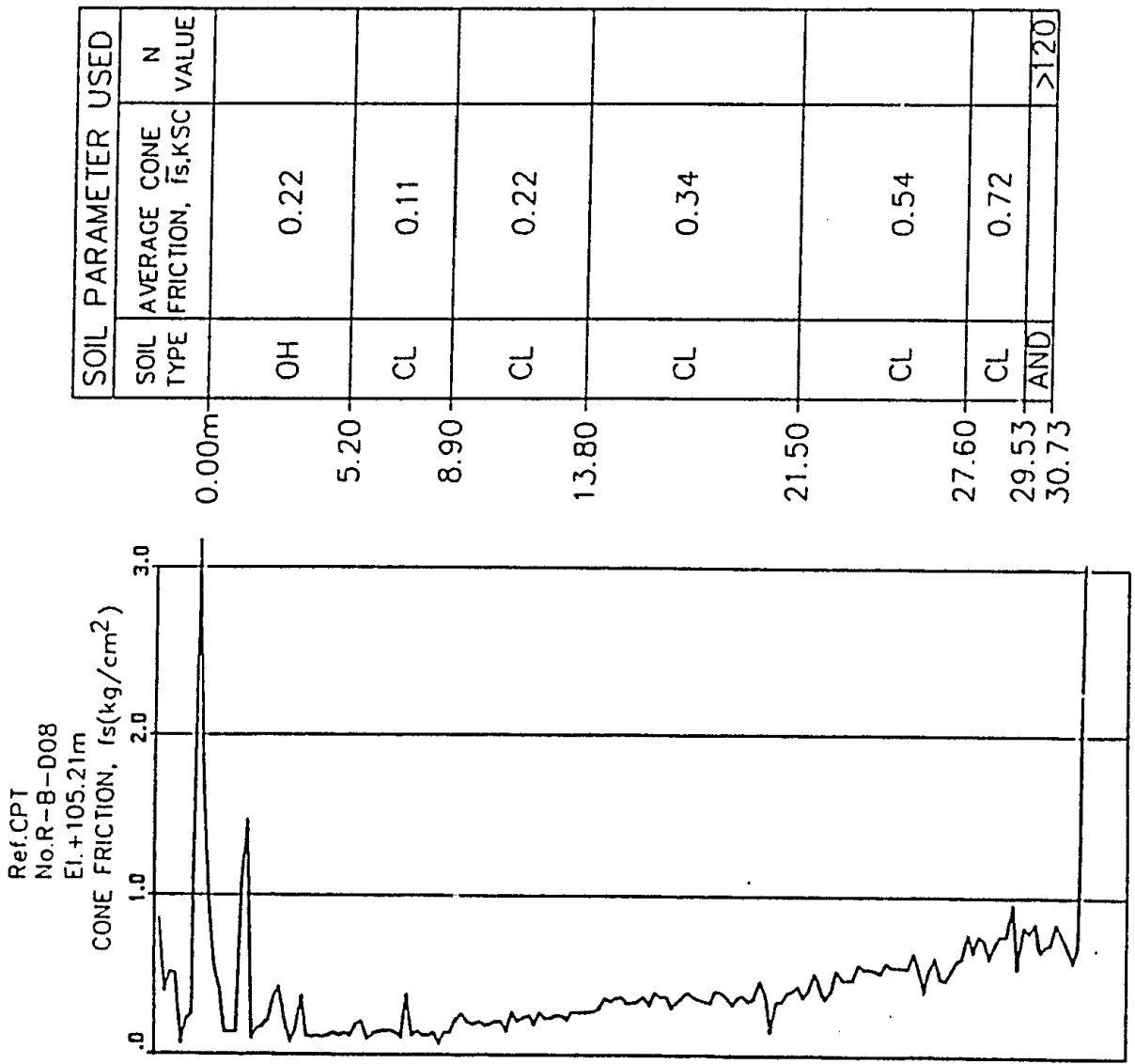

O1

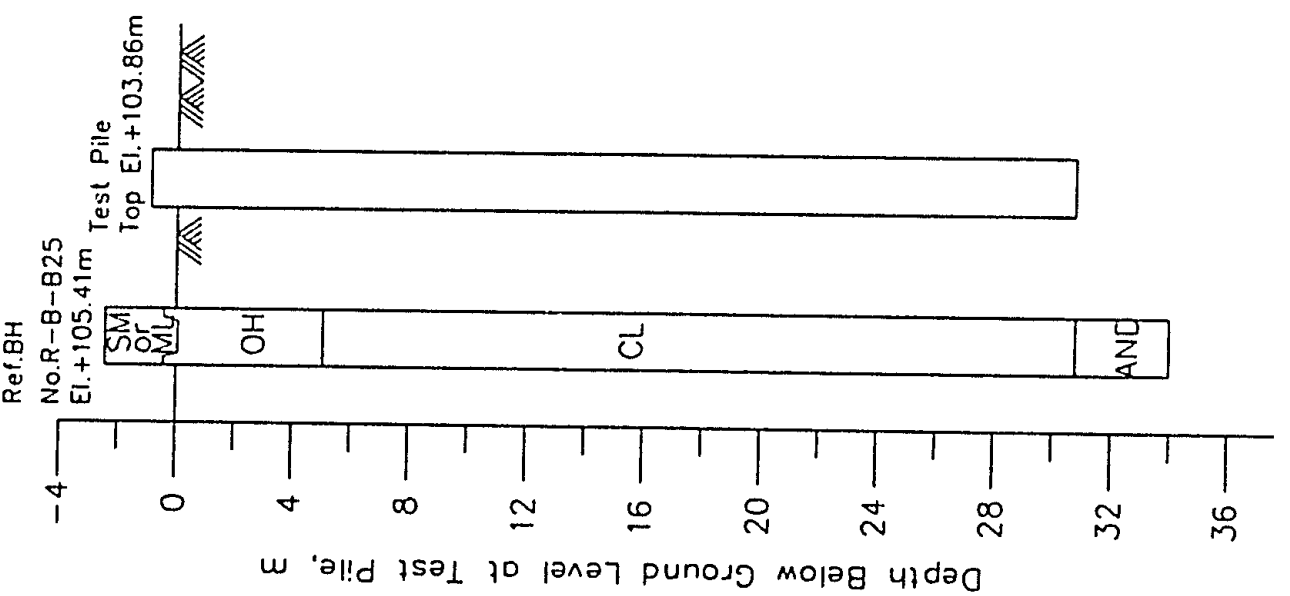



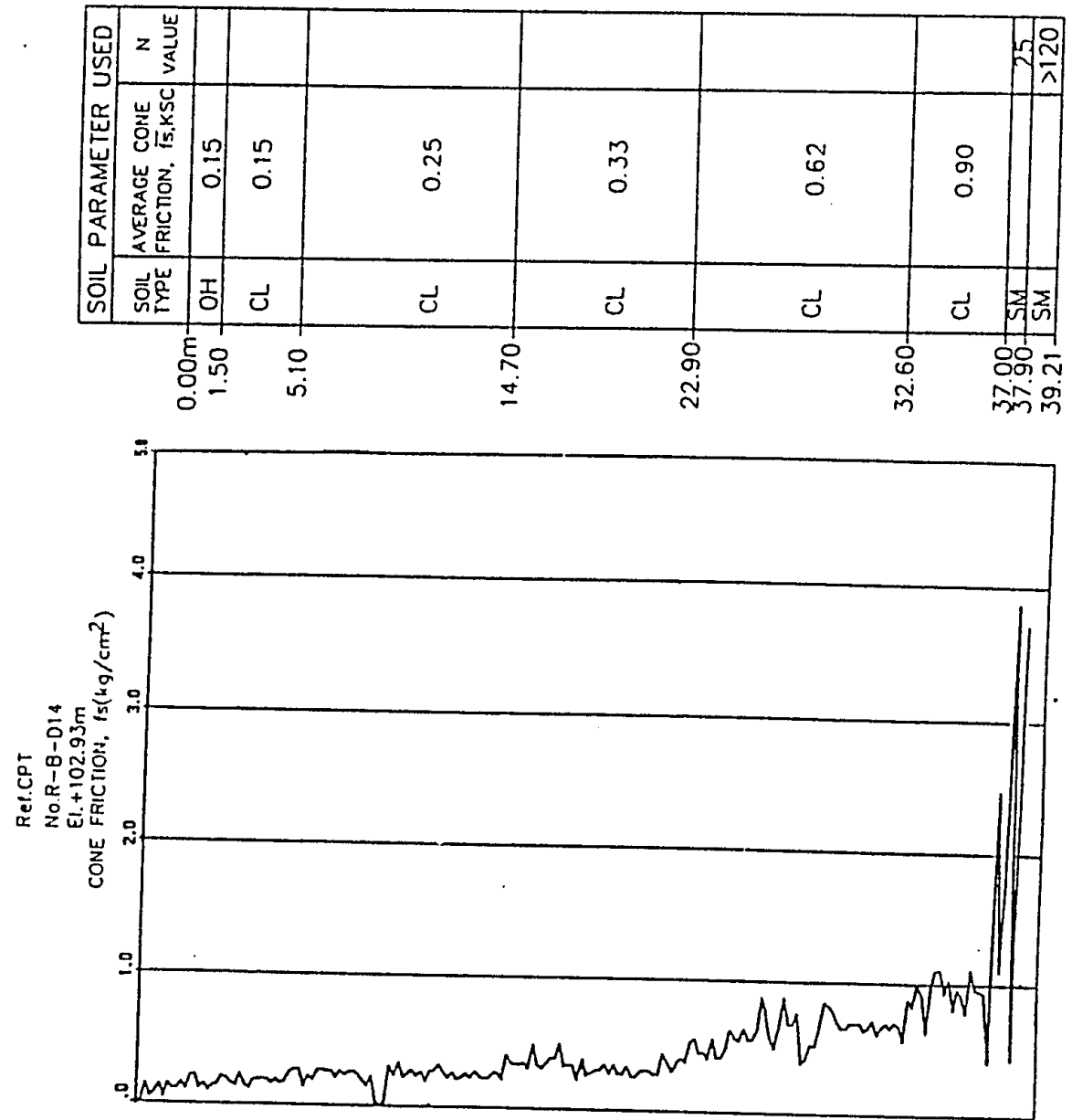

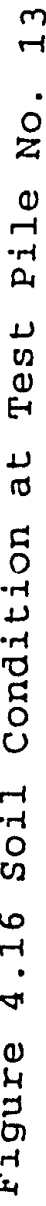

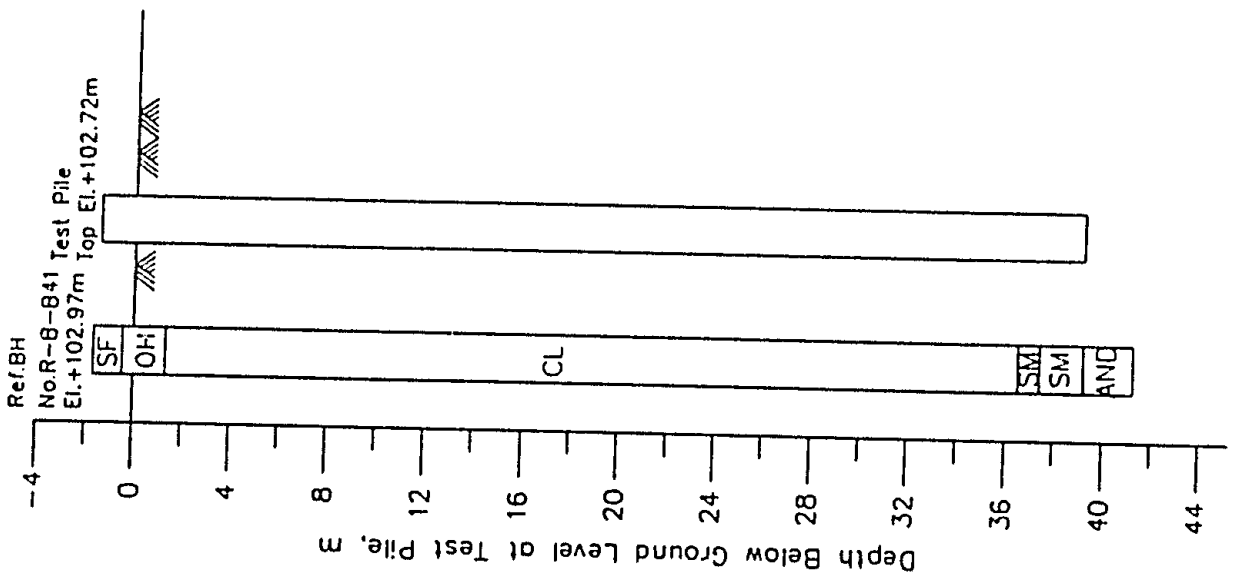




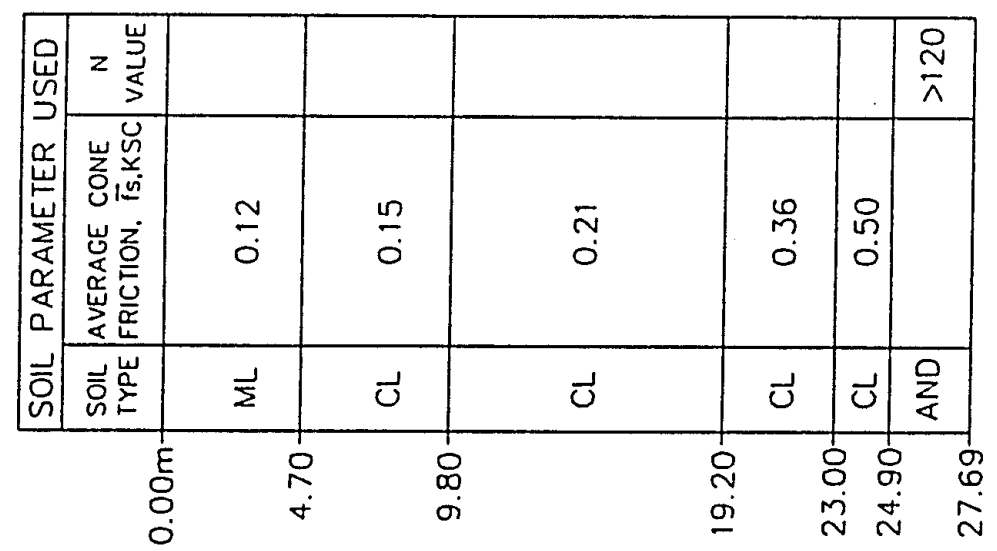

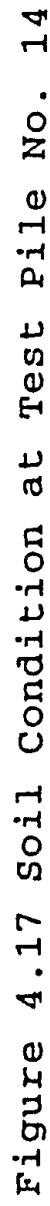
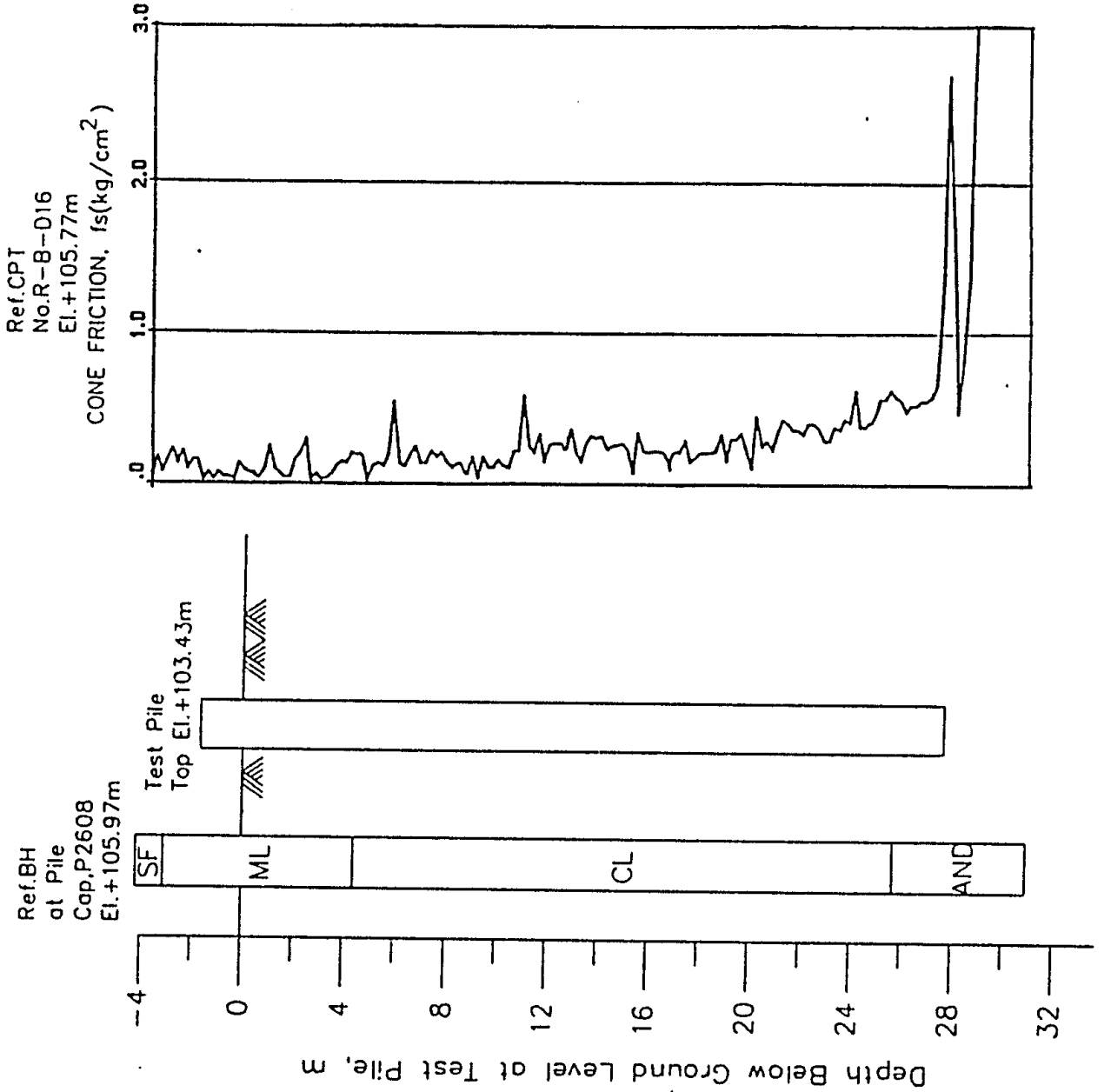


\begin{tabular}{|c|c|c|c|c|c|c|c|}
\hline 㥕 & 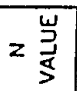 & & & & & & $\stackrel{\sim}{\sim}$ \\
\hline 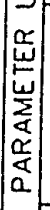 & 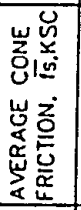 & $\frac{n}{0}$ & $\stackrel{n}{\sim}$ & $\begin{array}{l}m \\
m \\
0\end{array}$ & $\begin{array}{l}\tilde{N} \\
0 \\
0\end{array}$ & $\begin{array}{l}\text { o. } \\
\text { o. }\end{array}$ & \\
\hline 흠 & 吉㞻 & I & $\vec{u}$ & $\vec{u}$ & $\vec{\circlearrowleft}$ & $\vec{d}$ & $\sum$ \\
\hline & & & & & & & $?$ \\
\hline
\end{tabular}

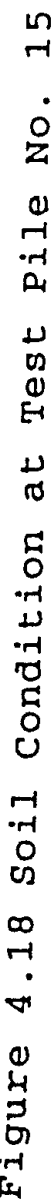
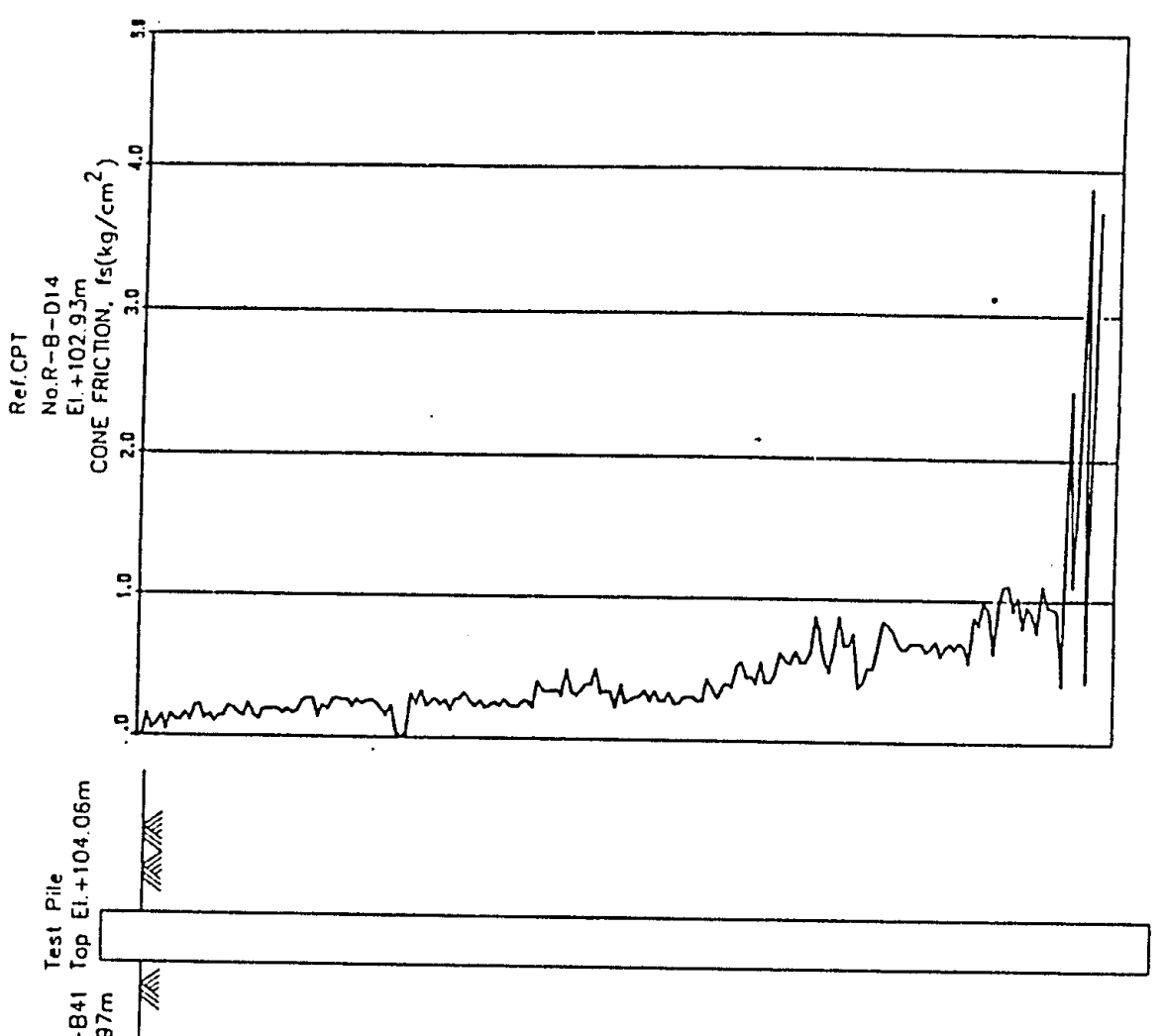

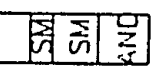

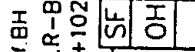

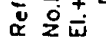

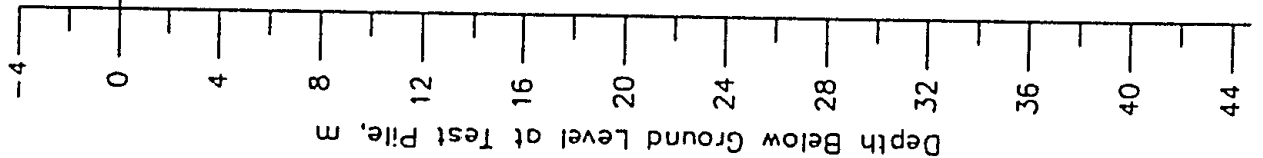




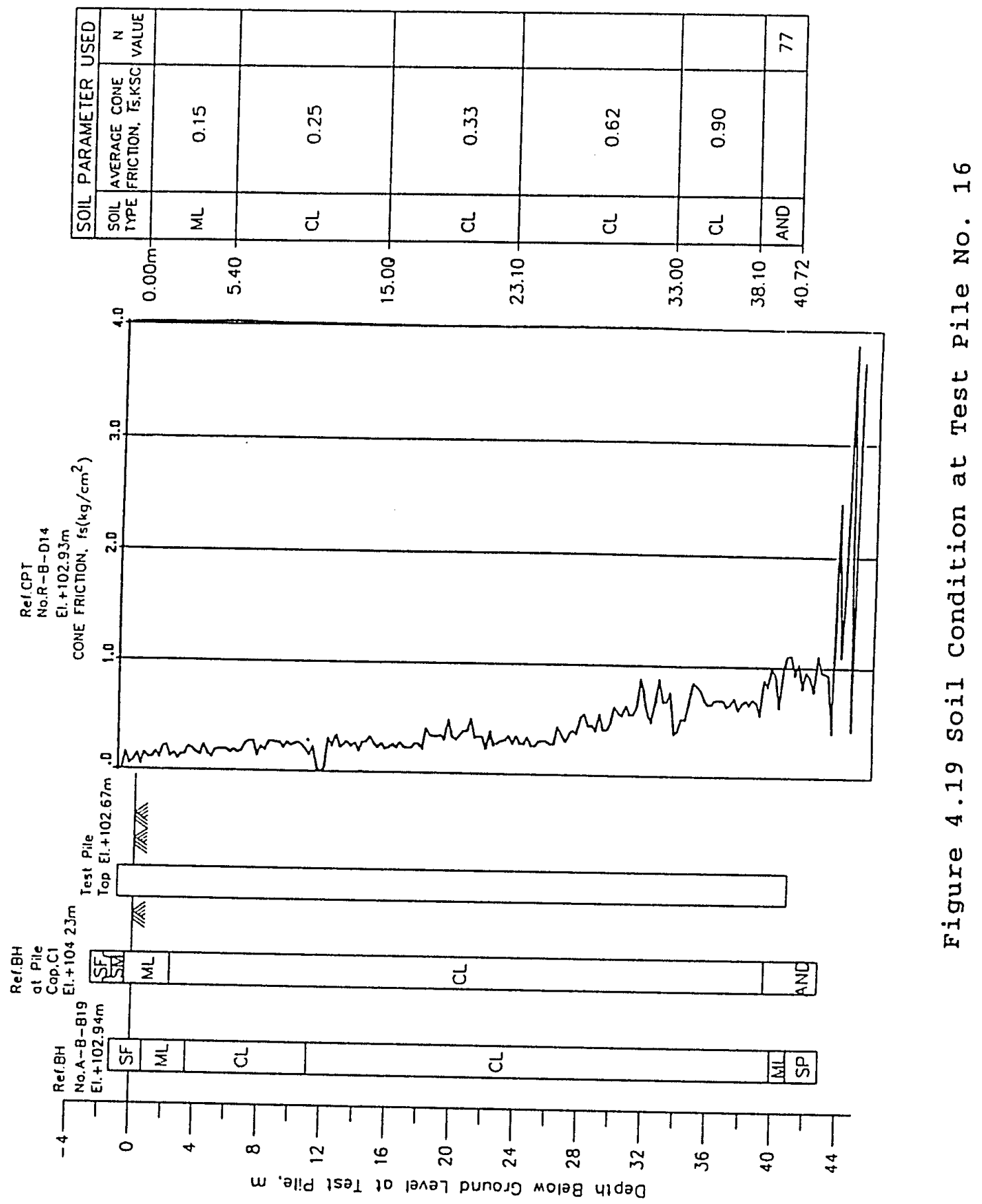



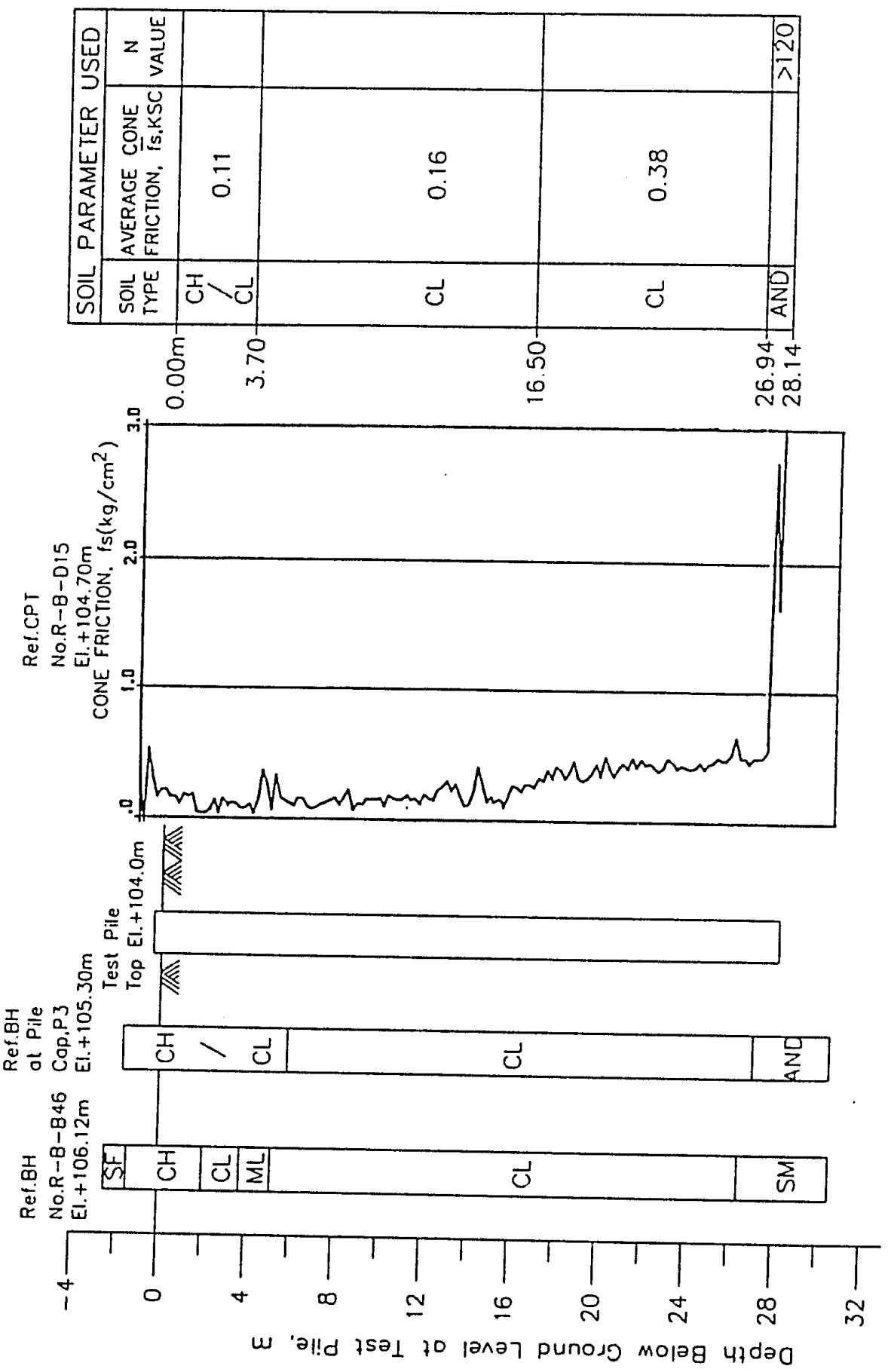

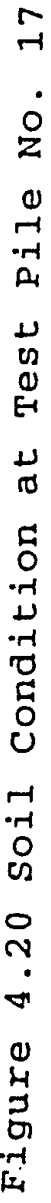




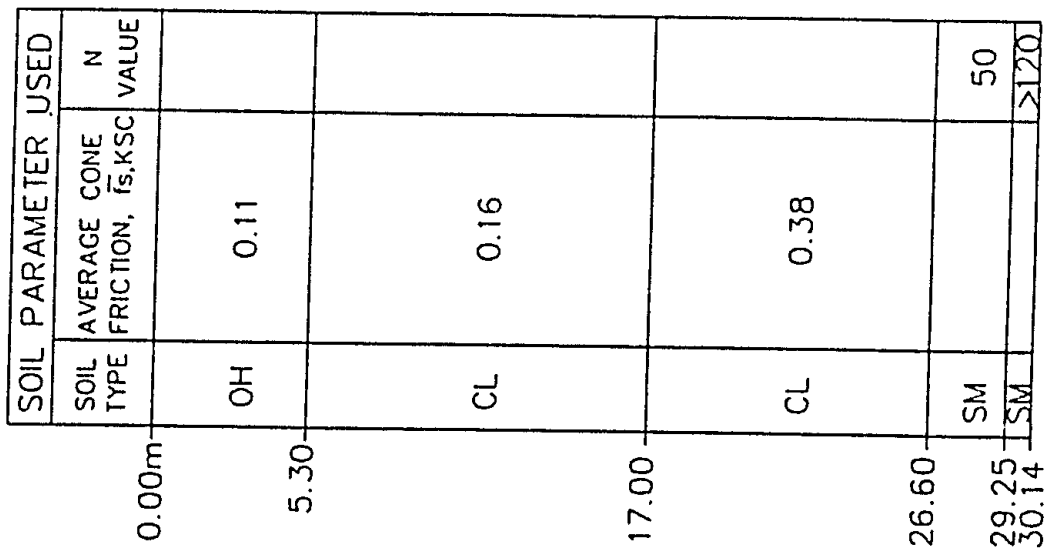

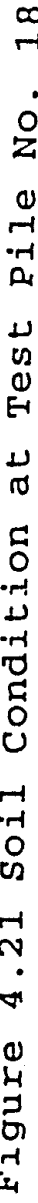

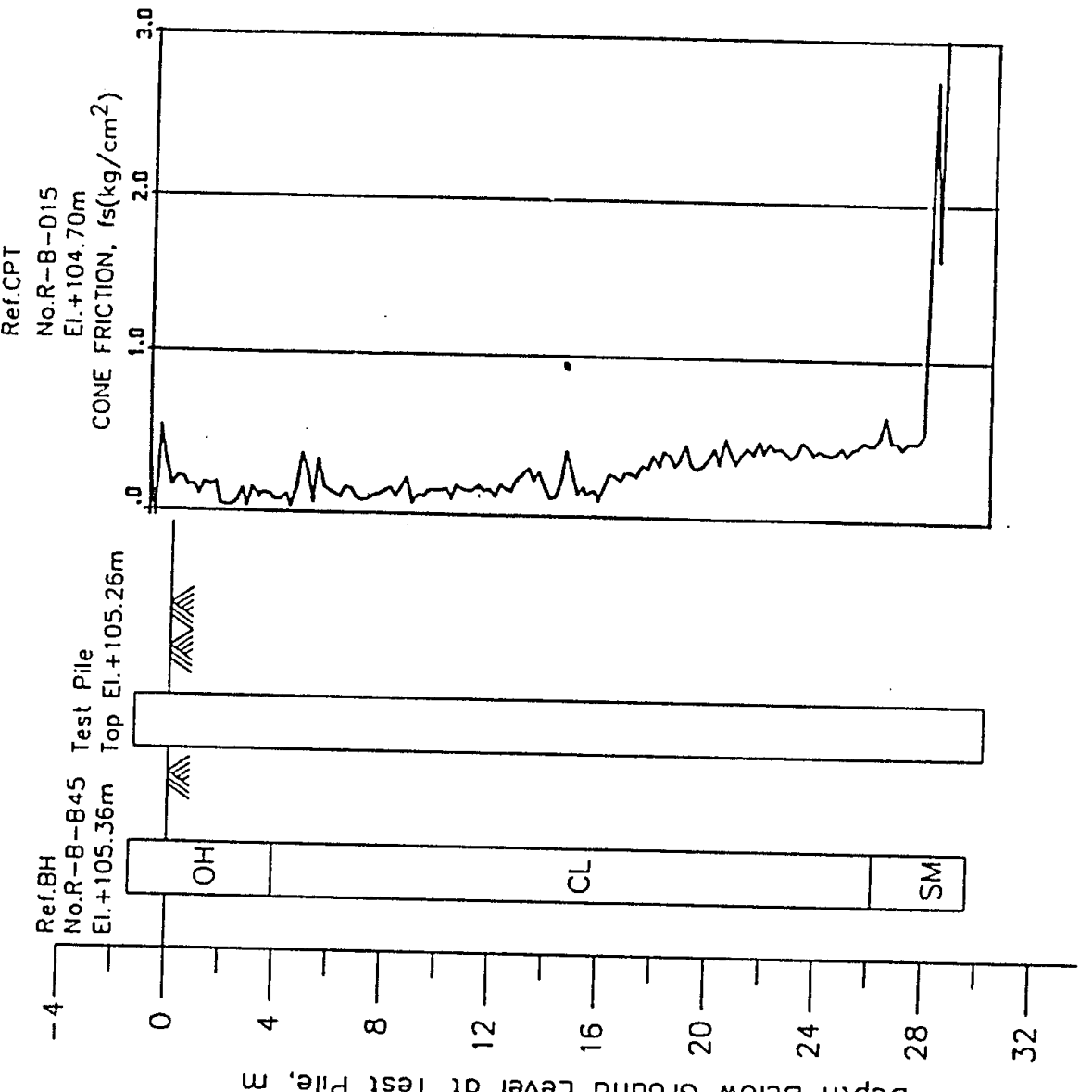

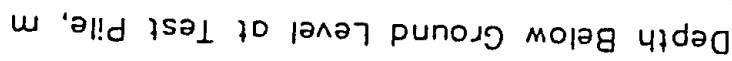




\subsection{Cone penetration Test}

\subsubsection{Apparatus}

The apparatus consists of a hydraulical thrust machine (manufactured by N. V. GOUDSCHE MACHINE FABRIEK, NETHERLANDS ), a set of tubes containing pressure rods inside, and cone. The mechanical friction-cone (Begemann type) as shown in Figure 4.22 was used to permit separate measurement of end bearing and side friction during the penetration. The cone has a 60-degree point angle with a projected area of 10 square centimeters.

\subsubsection{Preparation for Testing}

The surface of the location to be tested (approximately 2.0 $\mathrm{m} \times 2.0 \mathrm{~m}$ area) was prepared as a level plane, the thrust machine was then set up for a thrust direction in the vertical. The thrust machine was anchored as necessary (as shown in Figure 4.23) to balance the penetration reaction during penetrating to the required depth or resistance. 


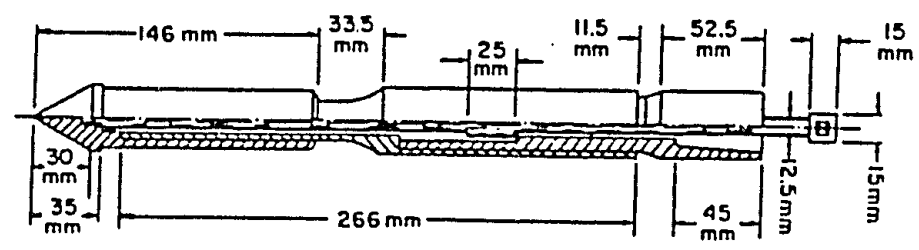

Collapsed

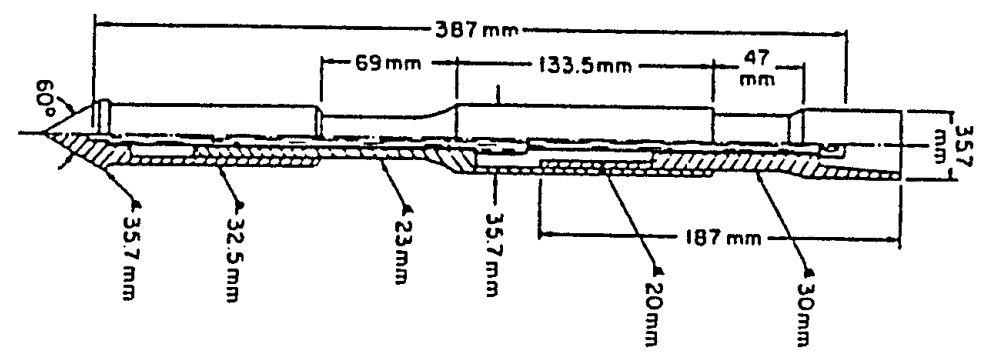

Extended

Figure 4.22 Mechanical Friction-cone Penetrometer Tip (Begemann Type) 


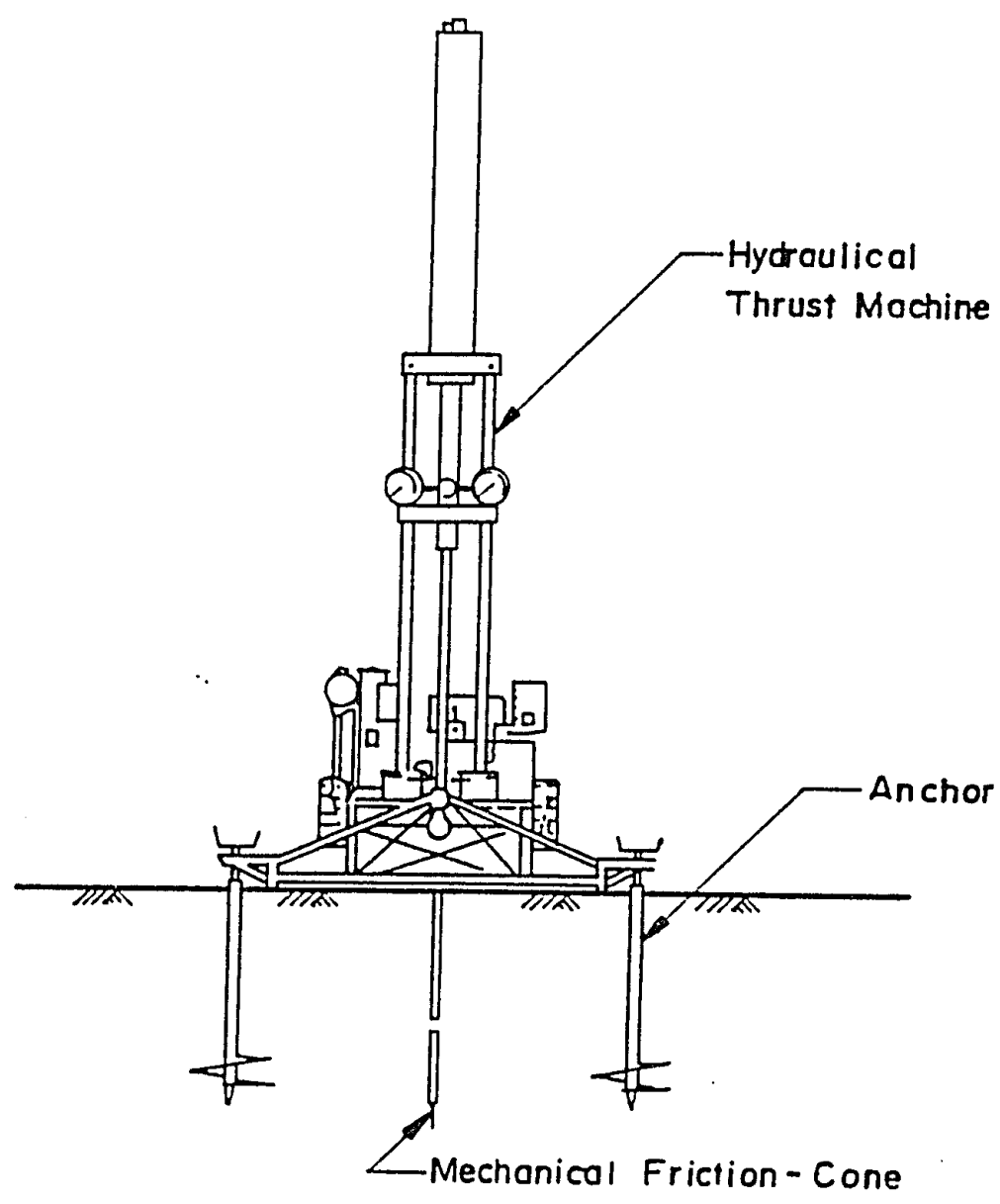

Figure 4.23 Dutch Cone Penetrometer 


\subsubsection{Testing procedure}

The procedure was conducted in accordance with ASTM D3441 as follows:

1. Assemble together the pressure rod, tube and cone in such a way as to make contact with the hydraulic measuring device.

2. Set the tip of cone to the testing point.

3. Advance the cone downward approximately $3.5 \mathrm{~cm}$ by applying force with a rate of $2 \mathrm{~cm} / \mathrm{sec}$. through the pressure rod. The cone would be extended beyond the friction sleeve upon which the local side, friction resistance developed. With the penetration above, two readings could be recorded from the measuring device, namely, 1) end bearing resistance or cone resistance, 2) the sum of sleeve frictional resistance and cone resistance.

4. Repeat steps 2 and 3 from the surface to the required depth (or up to the maximum resistance that the machine could balance) with $20 \mathrm{~cm}$ intervals of penetration. Readings were taken at each penetration for cone resistance and sleeve frictional resistance calculations. 


\subsection{Pile Description and Installation}

Cast-in-situ bored piles, which are called reverse circulation piles in Taiwan, have been successfully used for supporting many bridges, flyovers and high-rise buildings. For installation of this type of pile, a hole is first bored by a drill bit. To prevent collapse of the hole, the hole is always filled with clay slurry. The slurry is also used to carry away the soil cuttings by suction through the bit. New slurry is pumped into the hole to maintain a constant head of fluid. After the desired depth is reached, a reinforcement is lowered and tremie concrete is placed to completely replace the slurry.

The general procedure for the installation of the piles was as follows:

1. Drive a temporary casing of diameter approximately $15 \mathrm{~cm}$ larger than the pile diameter, to the depth of 3 to $5 \mathrm{~m}$.

2. Start boring by a drilling bit within the casing while clay slurry was filled into the hole and the fluid level was maintained at a level not less than $1.0 \mathrm{~m}$ above the level of the external ground water, and generally up to the ground level (ground water was generally at $2.0 \mathrm{~m}$ below ground level).

3. Continue drilling to the required elevation under mud slurry, with soil cuttings carried away by suction through the bit. 
4. Clean the bottom of the hole by maintaining at least 30 min. of suction through the bit.

5. Withdraw the drilling bit and lower the reinforcement.

6. Place concrete through a tremie pipe with a rubber plunger in the pipe to separate the concrete from the slurry, while keeping the tremie tip well embedded in the concrete.

7. As slurry is completely replaced by the concrete, waste the first portion of the concrete flow, as this concrete is usually contaminated with mud.

8. Extract the temporary casing.

\subsection{Test Loading Procedure and Results}

The procedure for conducting the load tests was generally in accordance with ASTM Standard Method of Testing Piles Under Static Axial Compressive Load (D1143-81). All of the devices for measuring deflection at the top of the pile, including four dial gages, and an engineer's level were employed as described by ASTM. The load was applied by jacking against an overhead reaction with a hydraulic jack, which was monitored by an accurately calibrated hydraulic gage. The reaction for each test pile was provided by four, same diameter, tension piles. The distance between test pile and tension piles was at least 

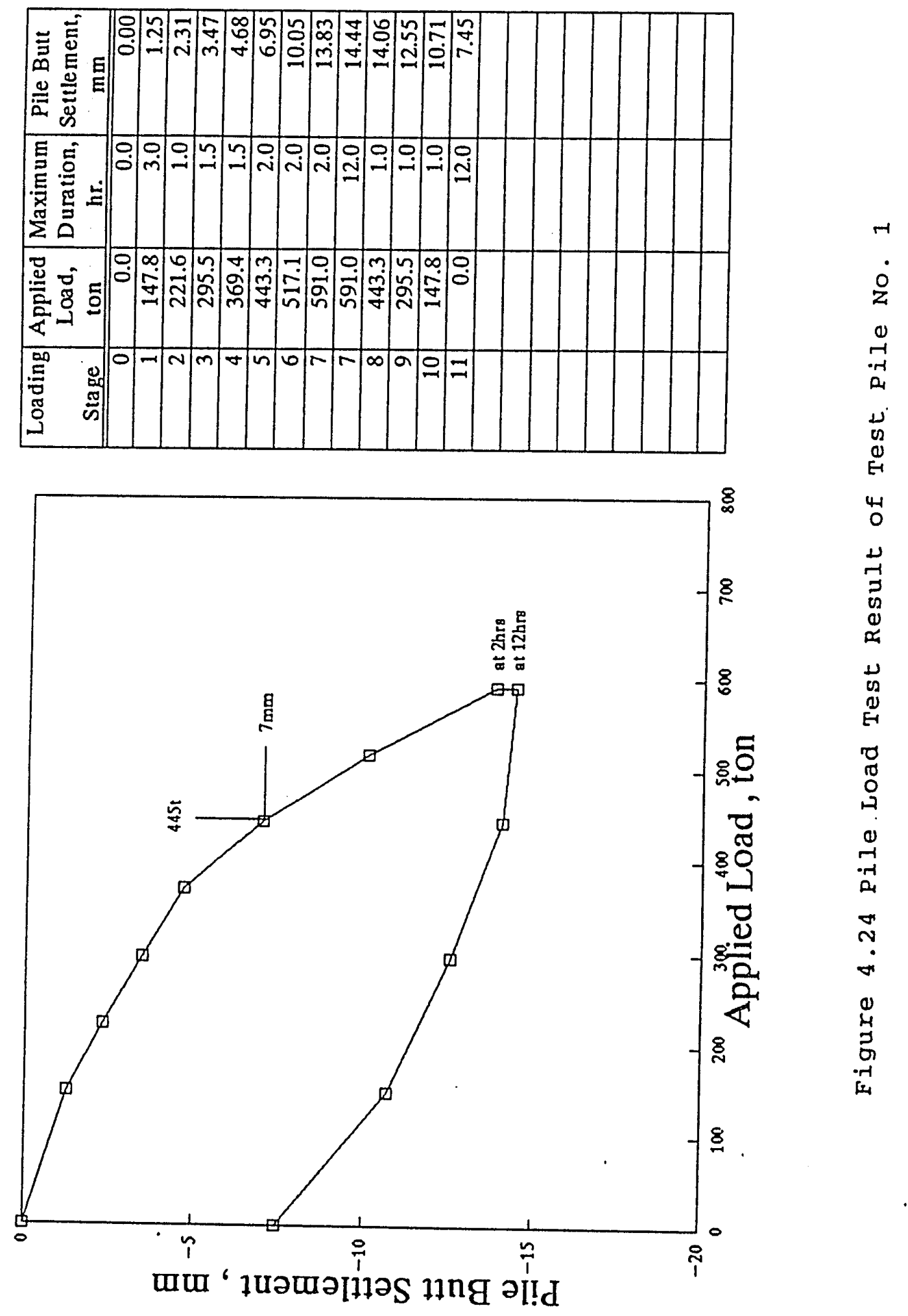

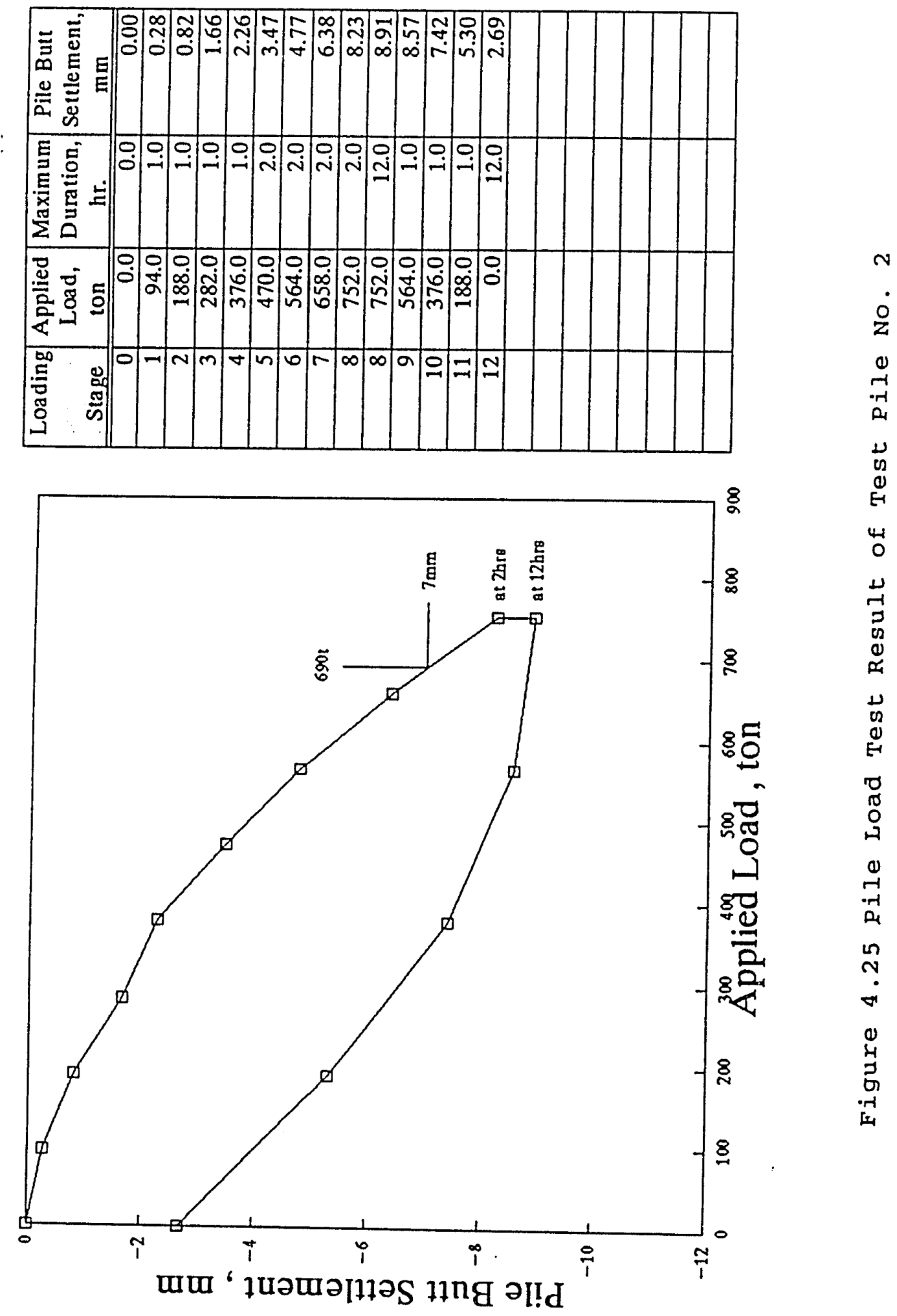

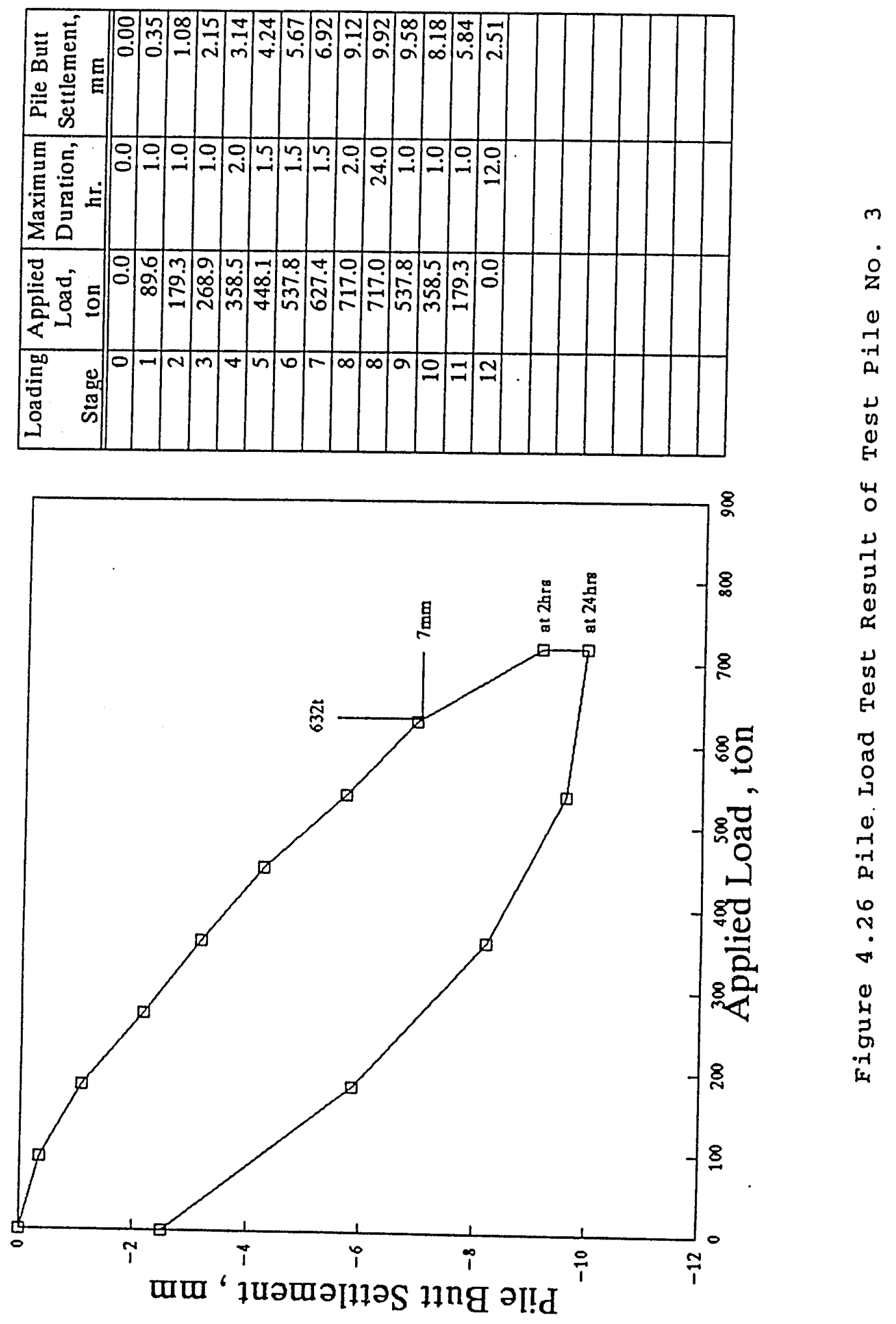

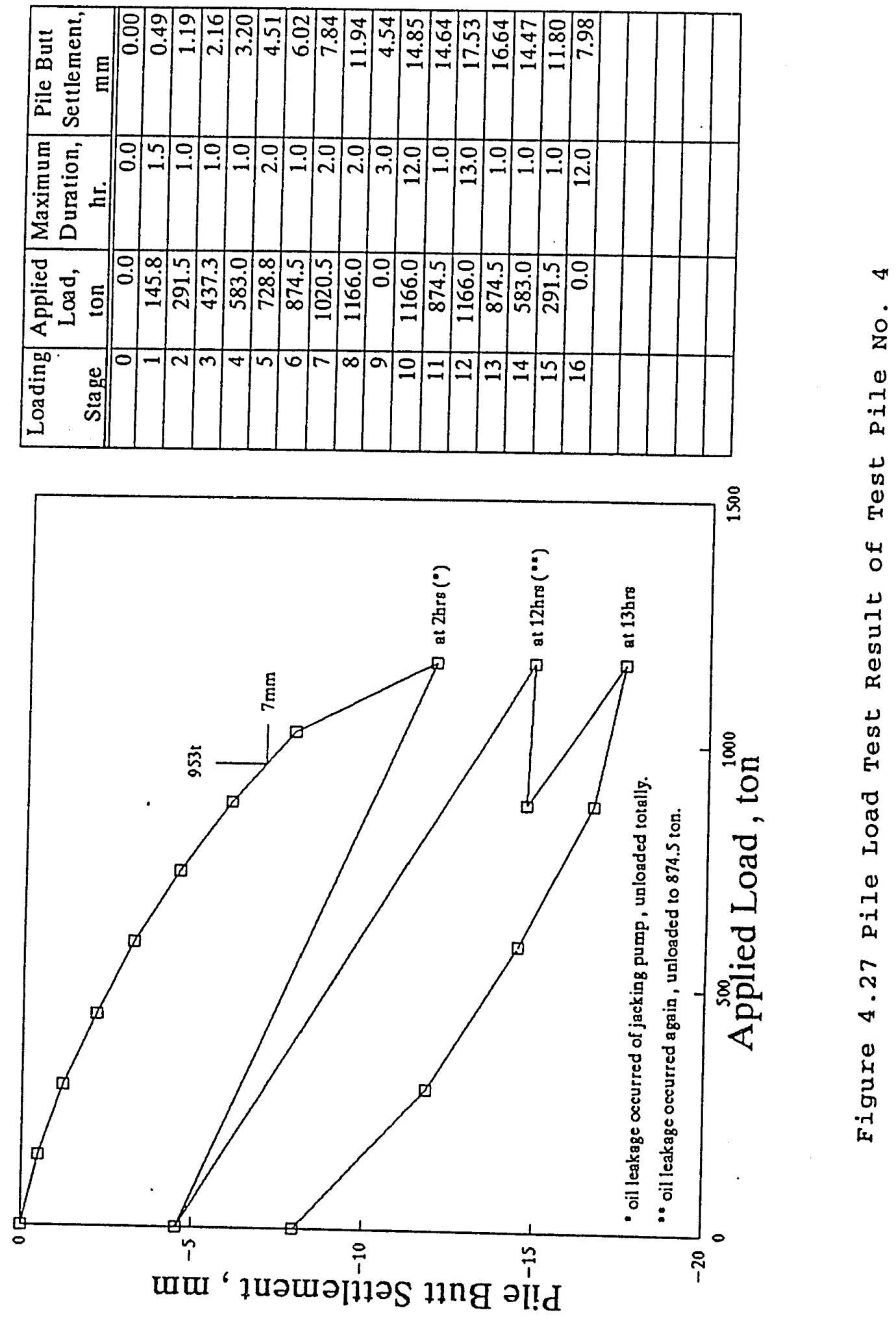

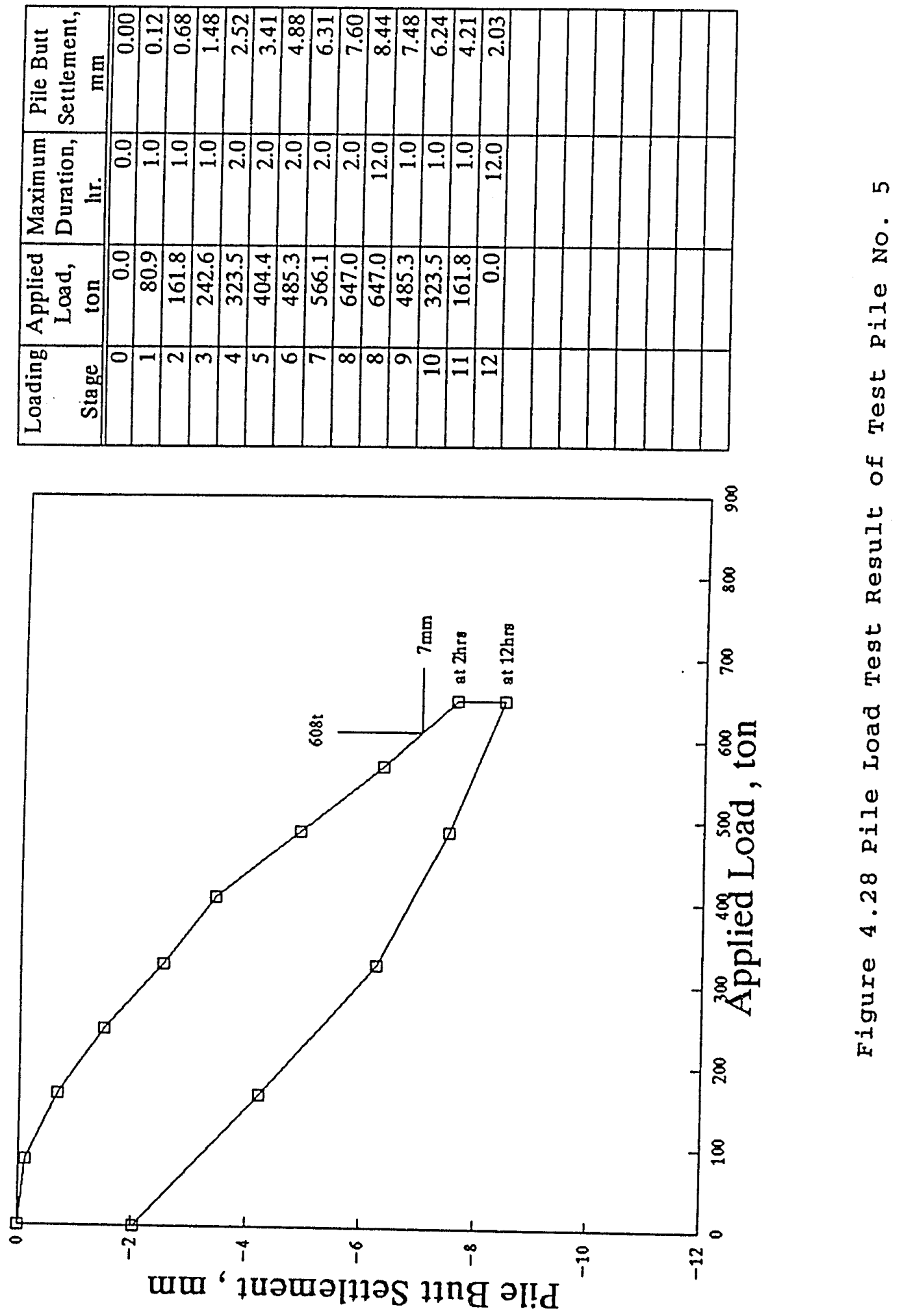

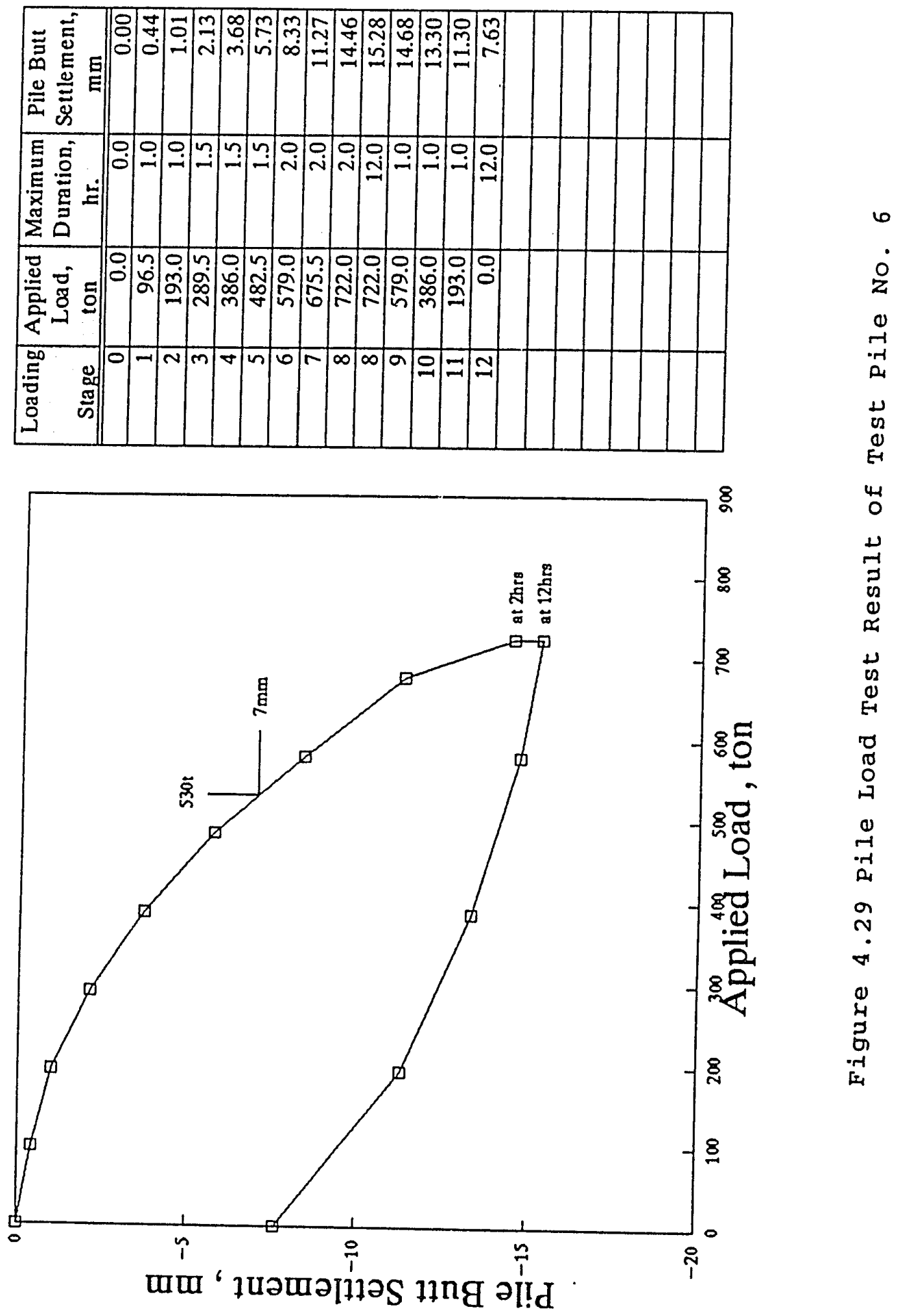

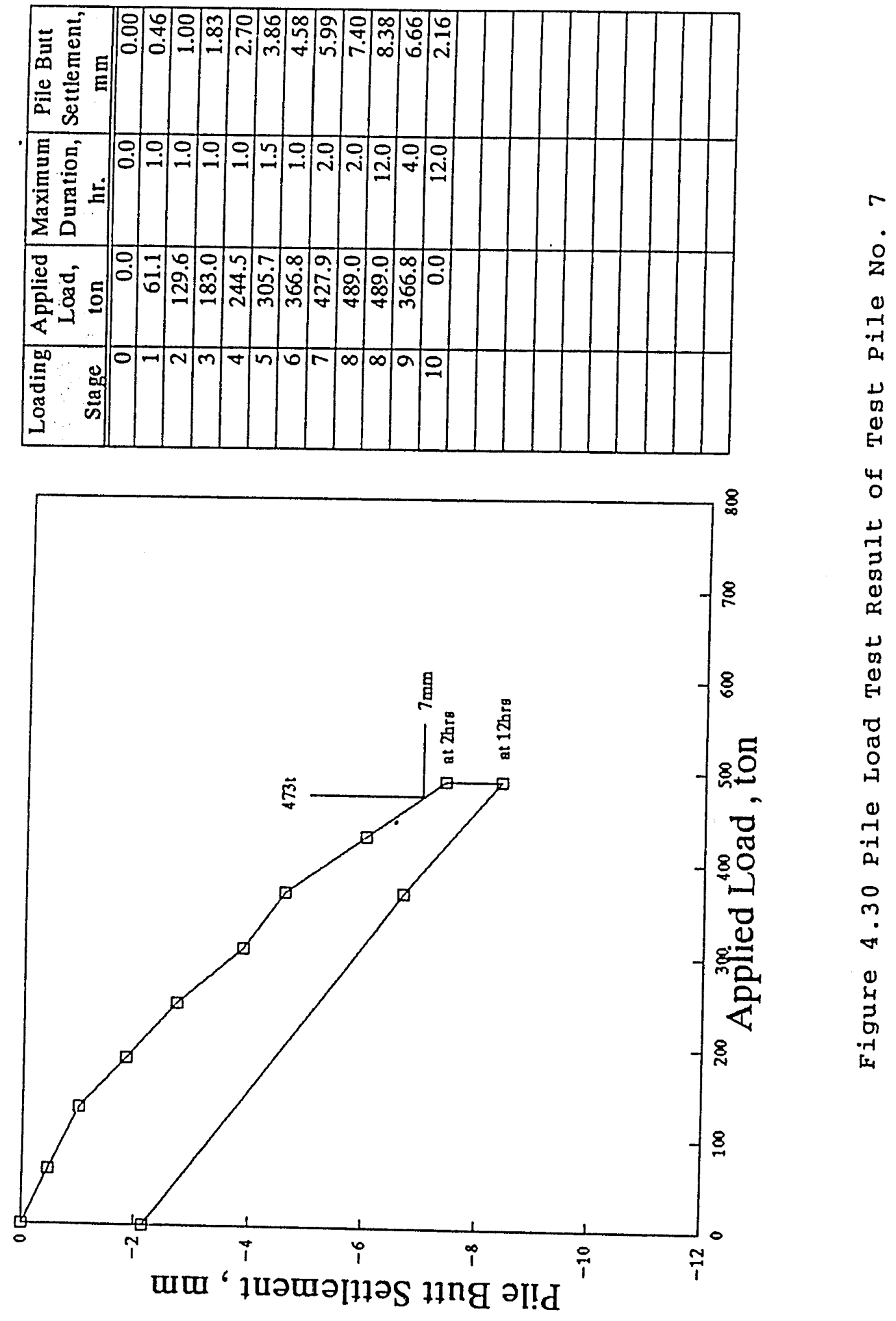

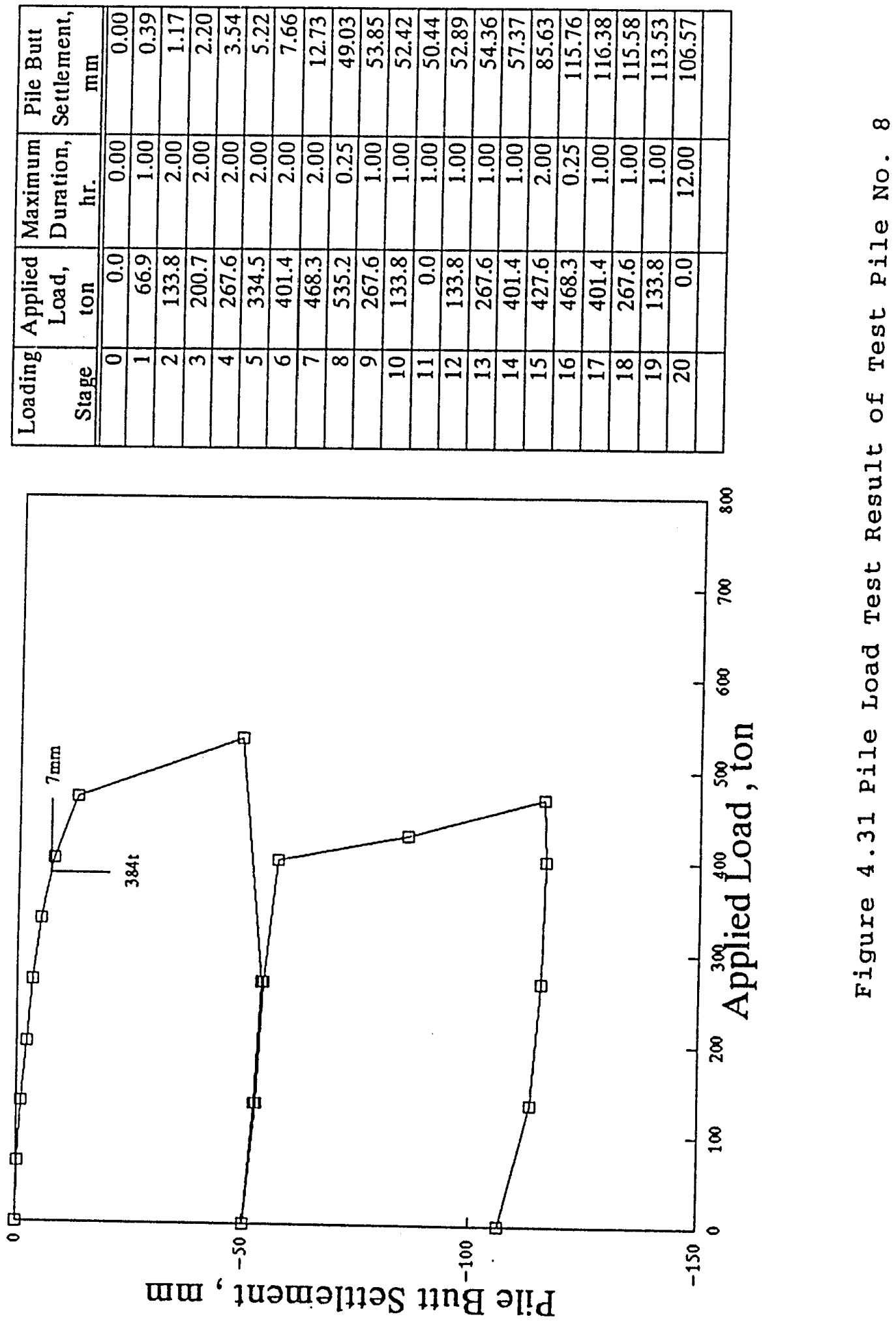

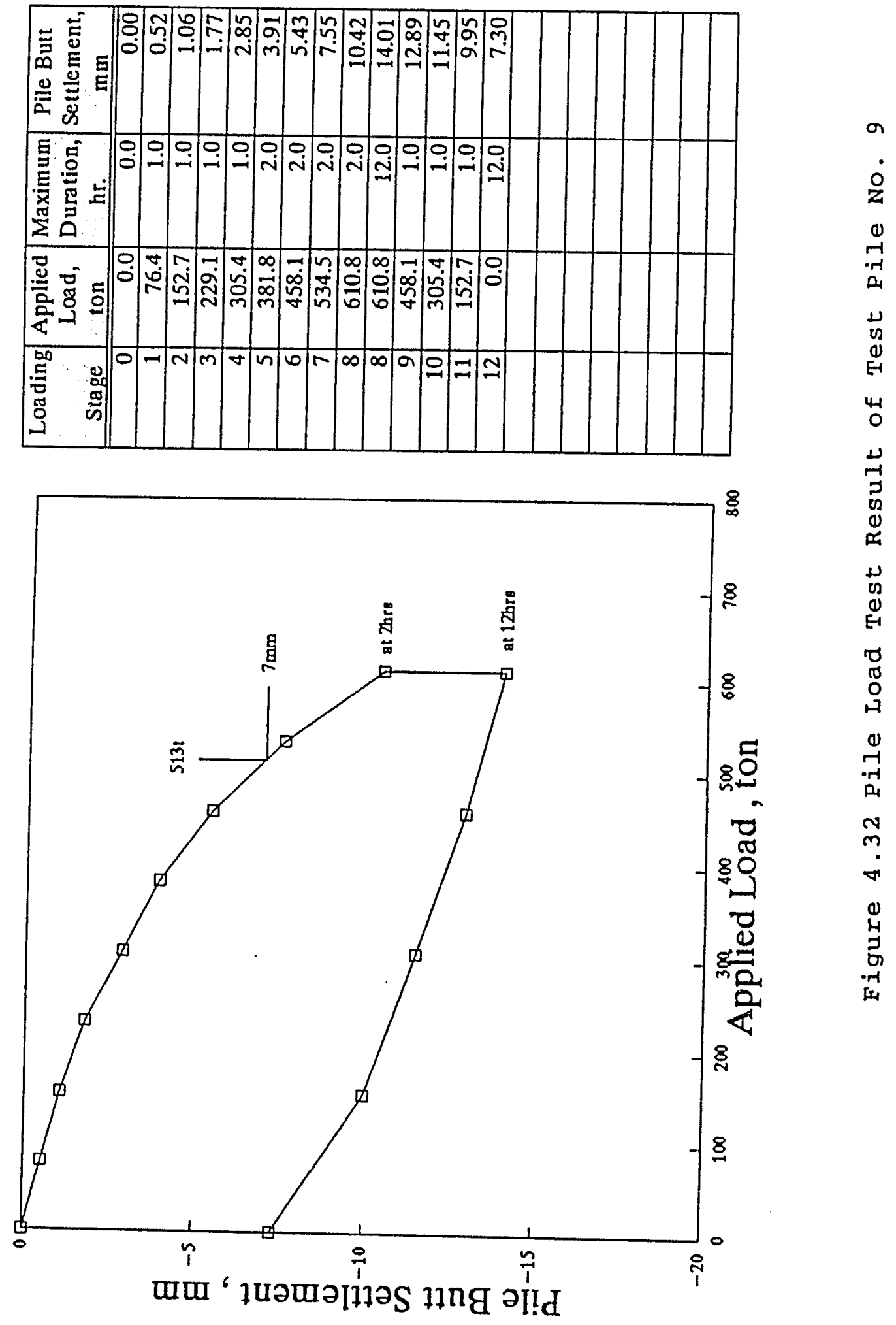

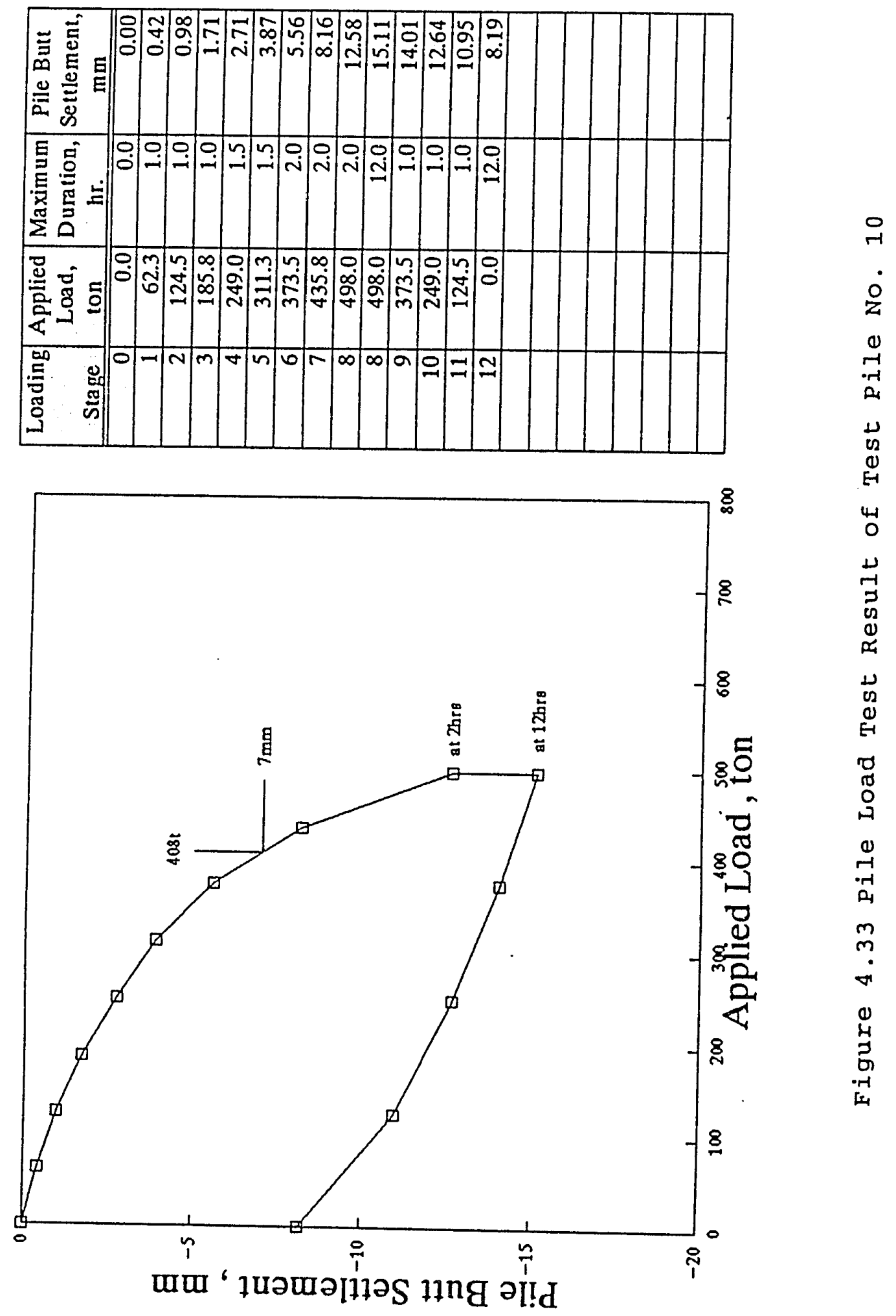

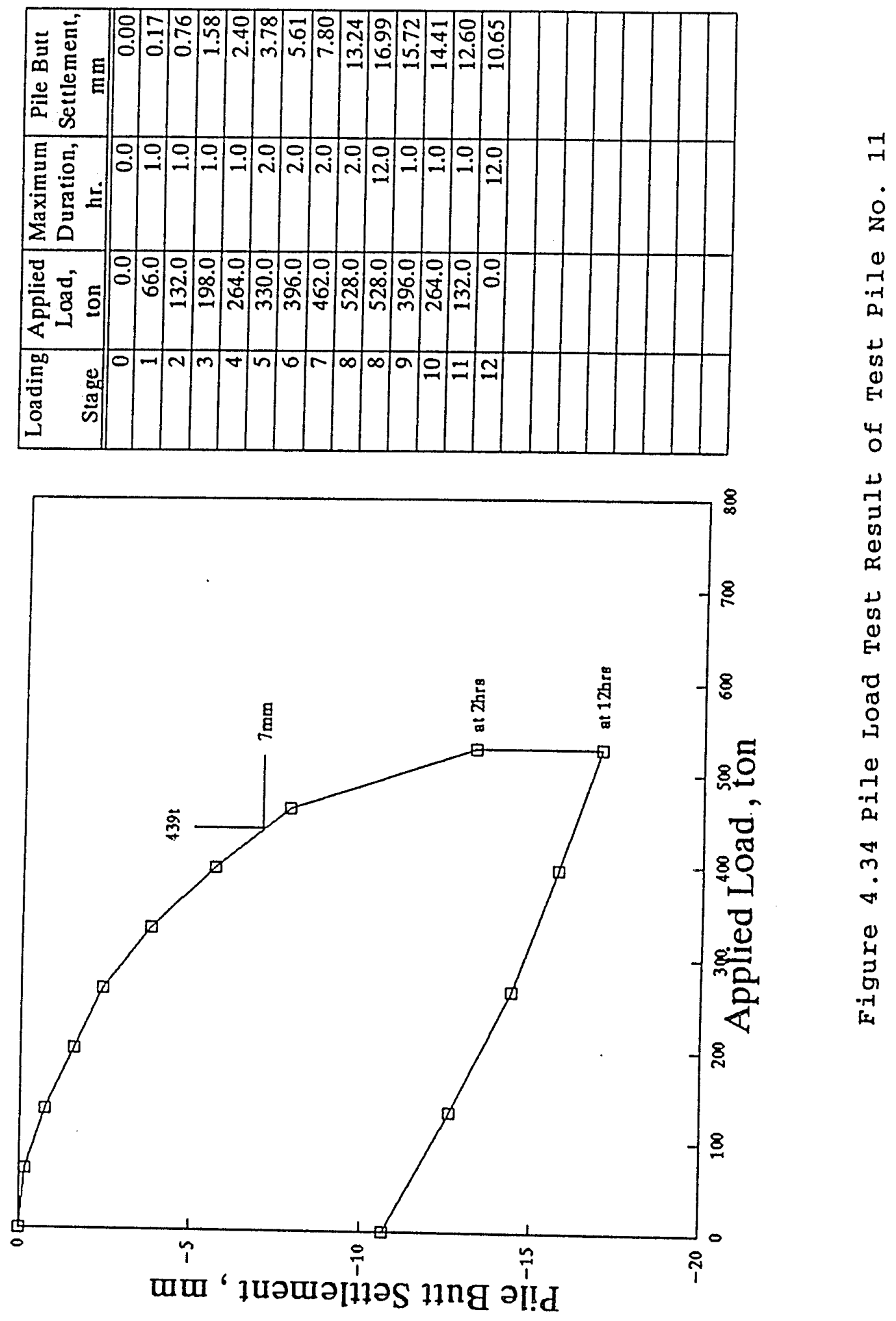

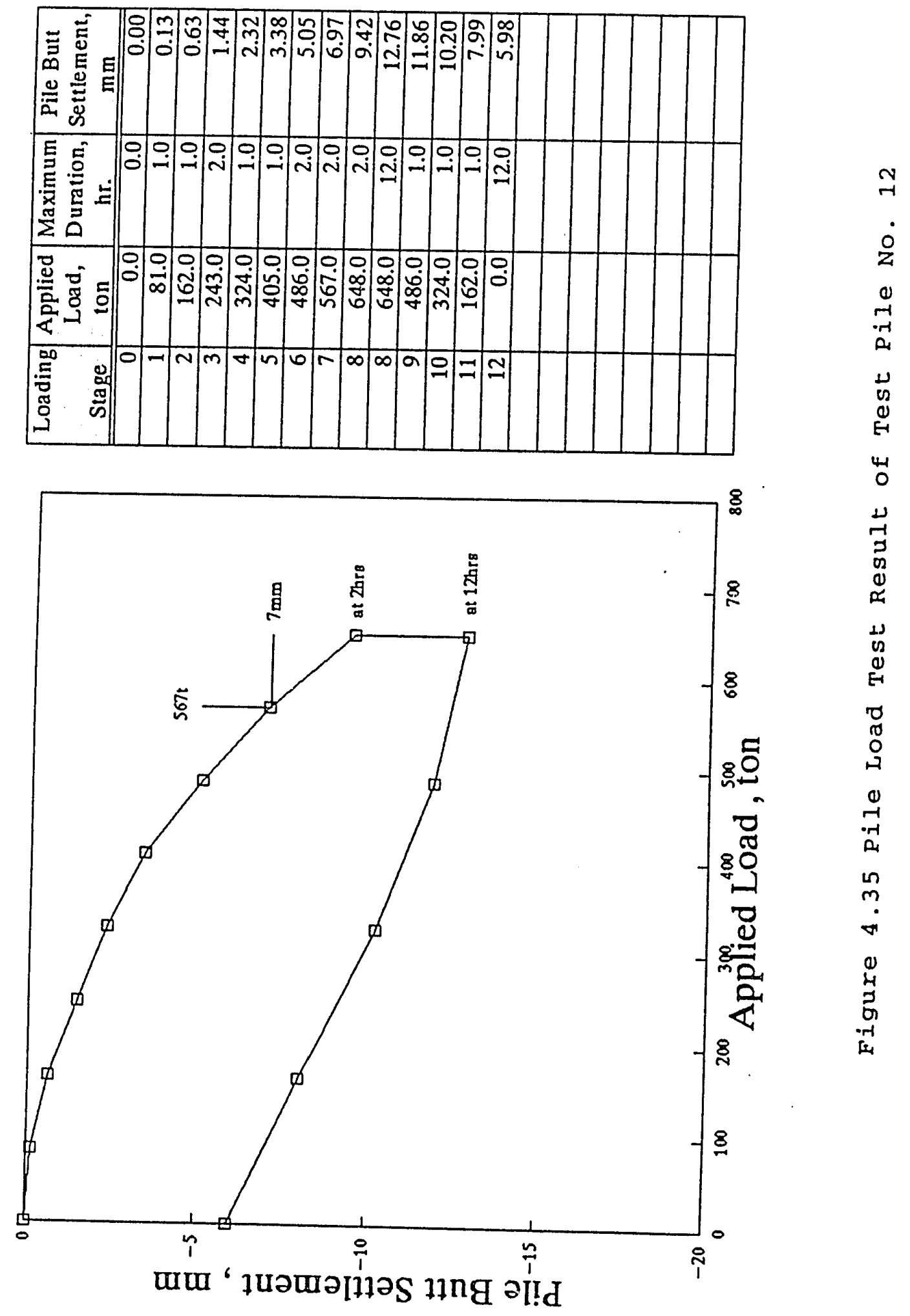

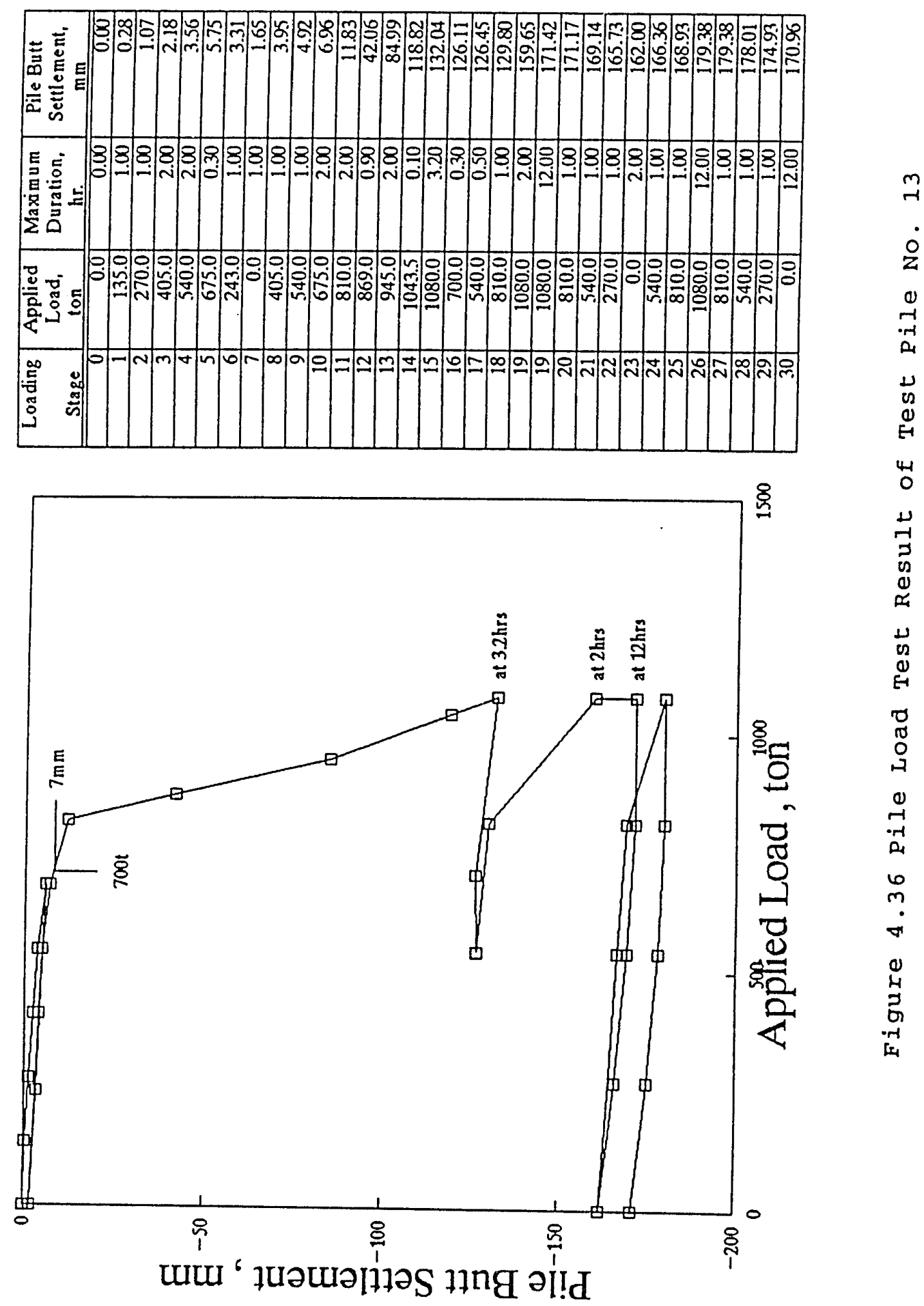

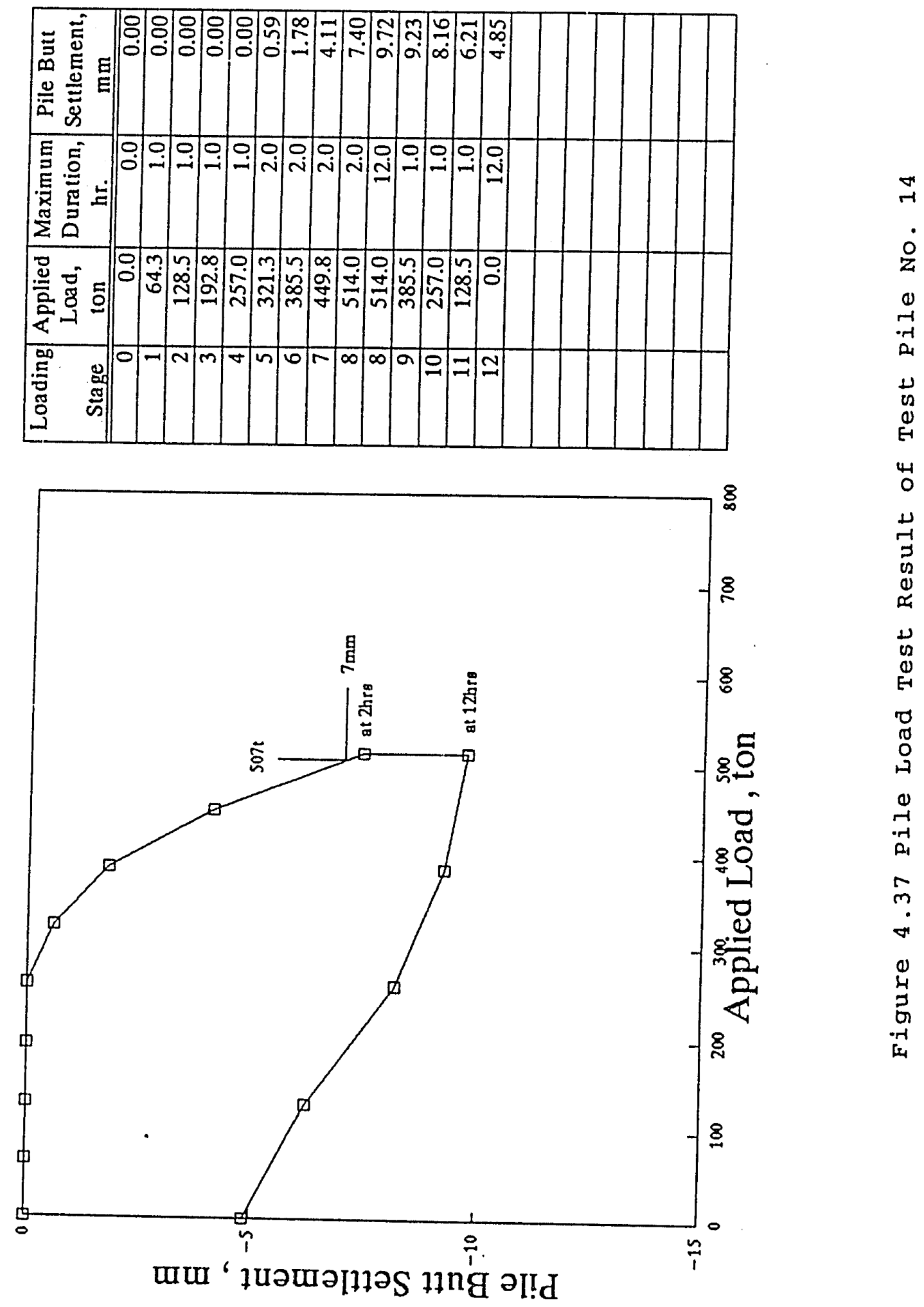

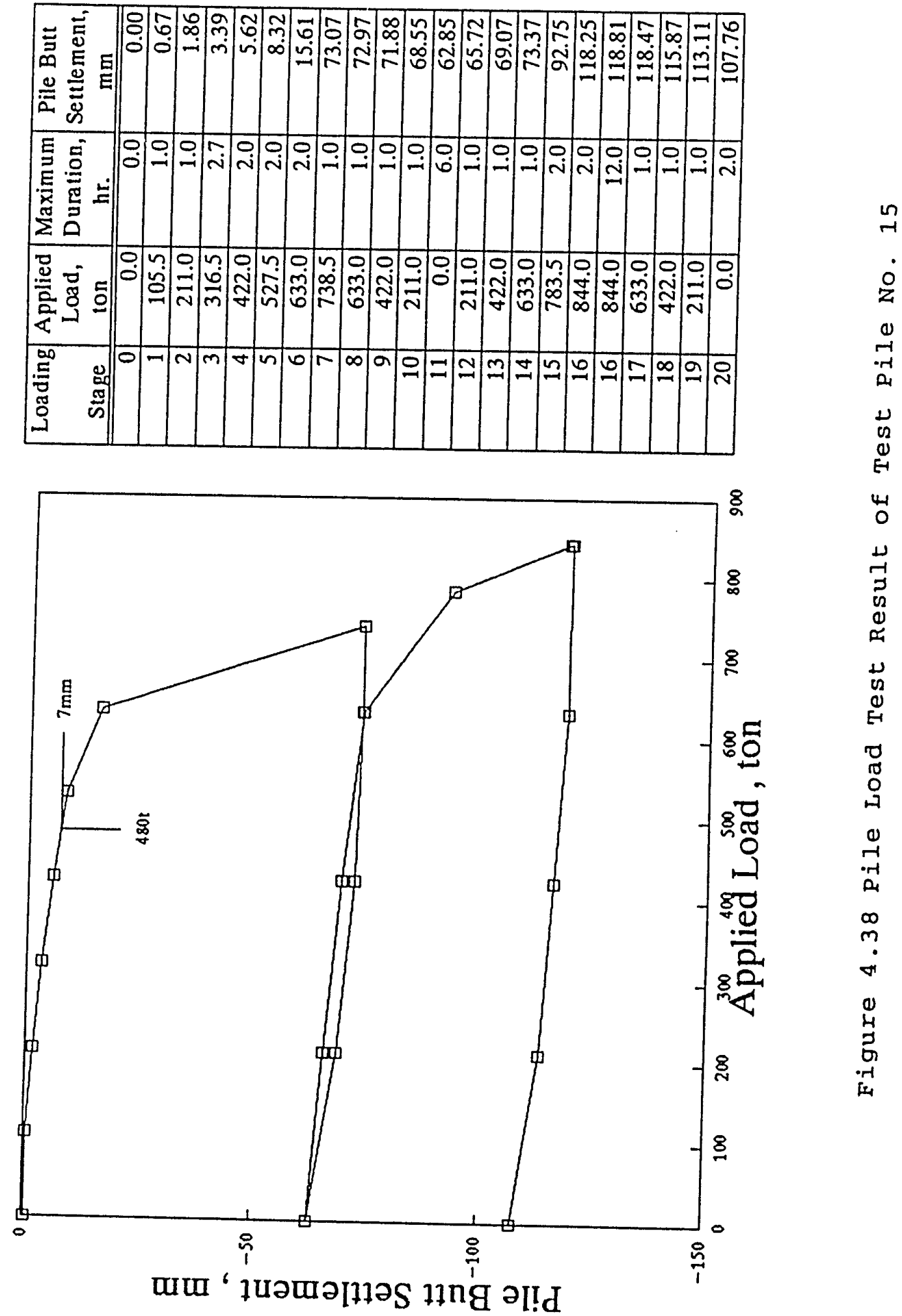


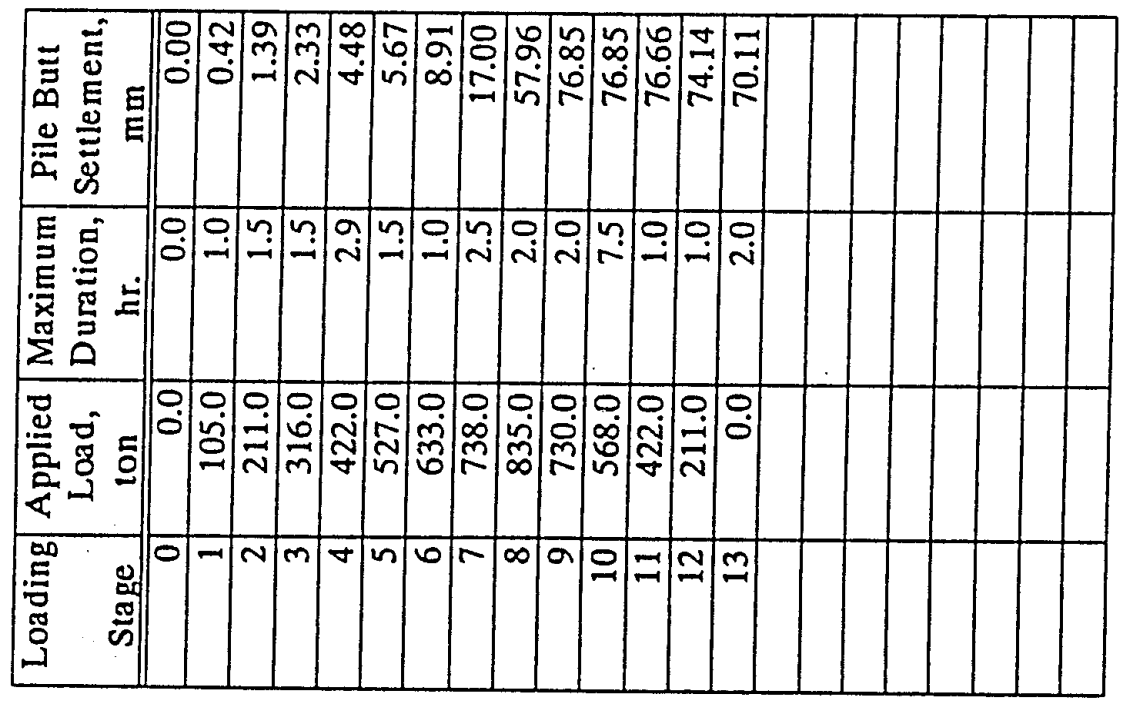

$\stackrel{6}{-1}$

o

$\stackrel{0}{-1}$

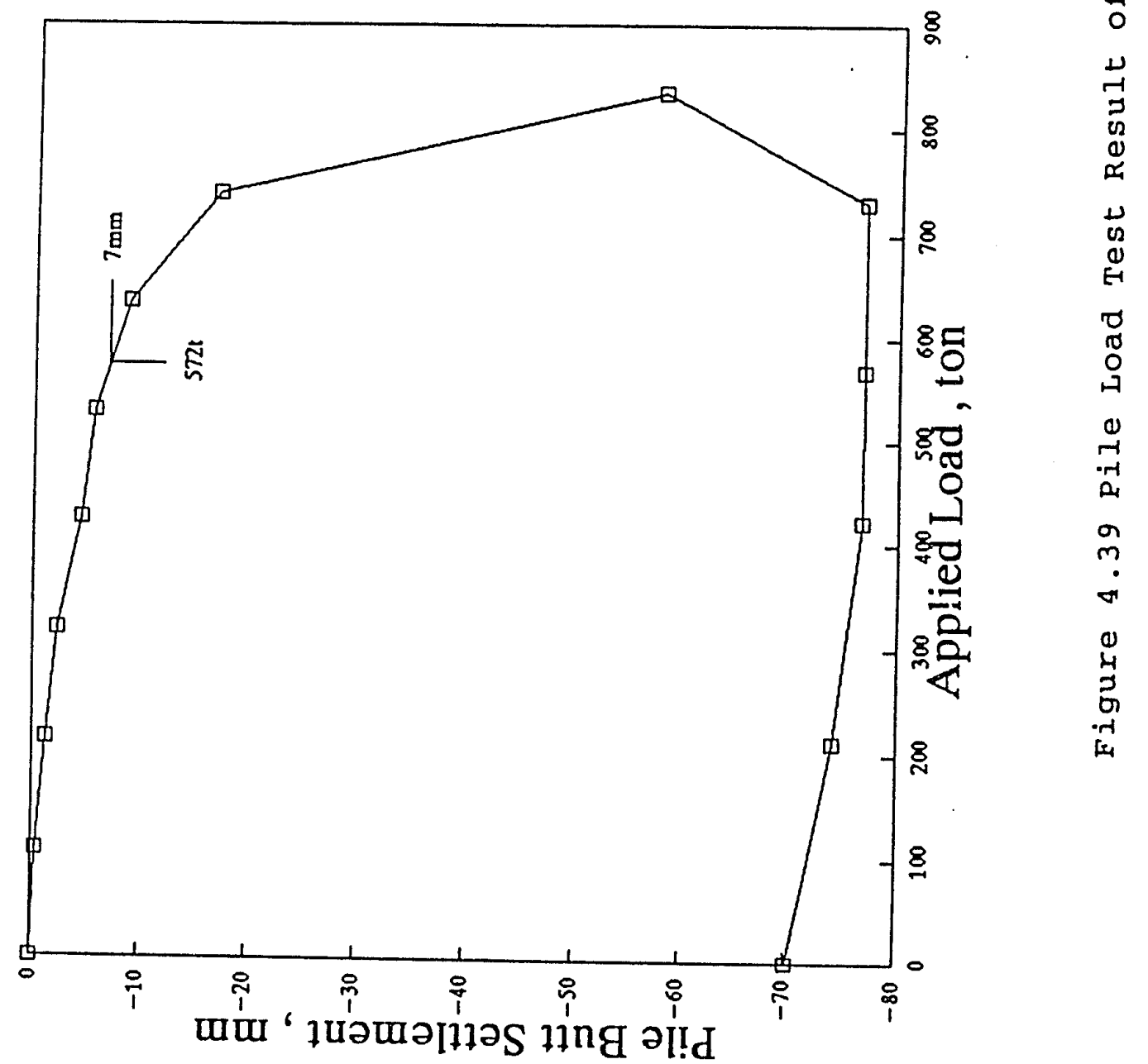



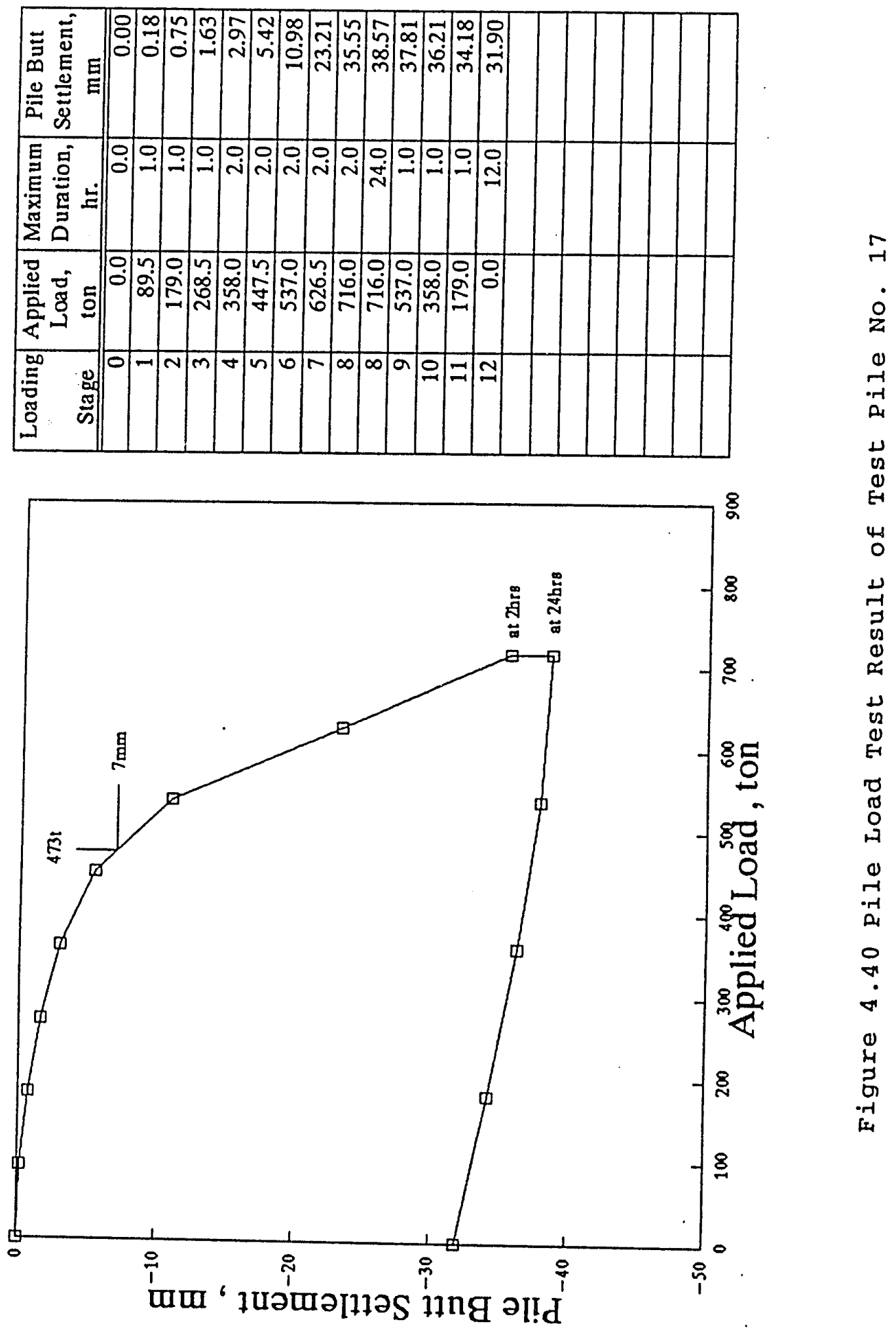

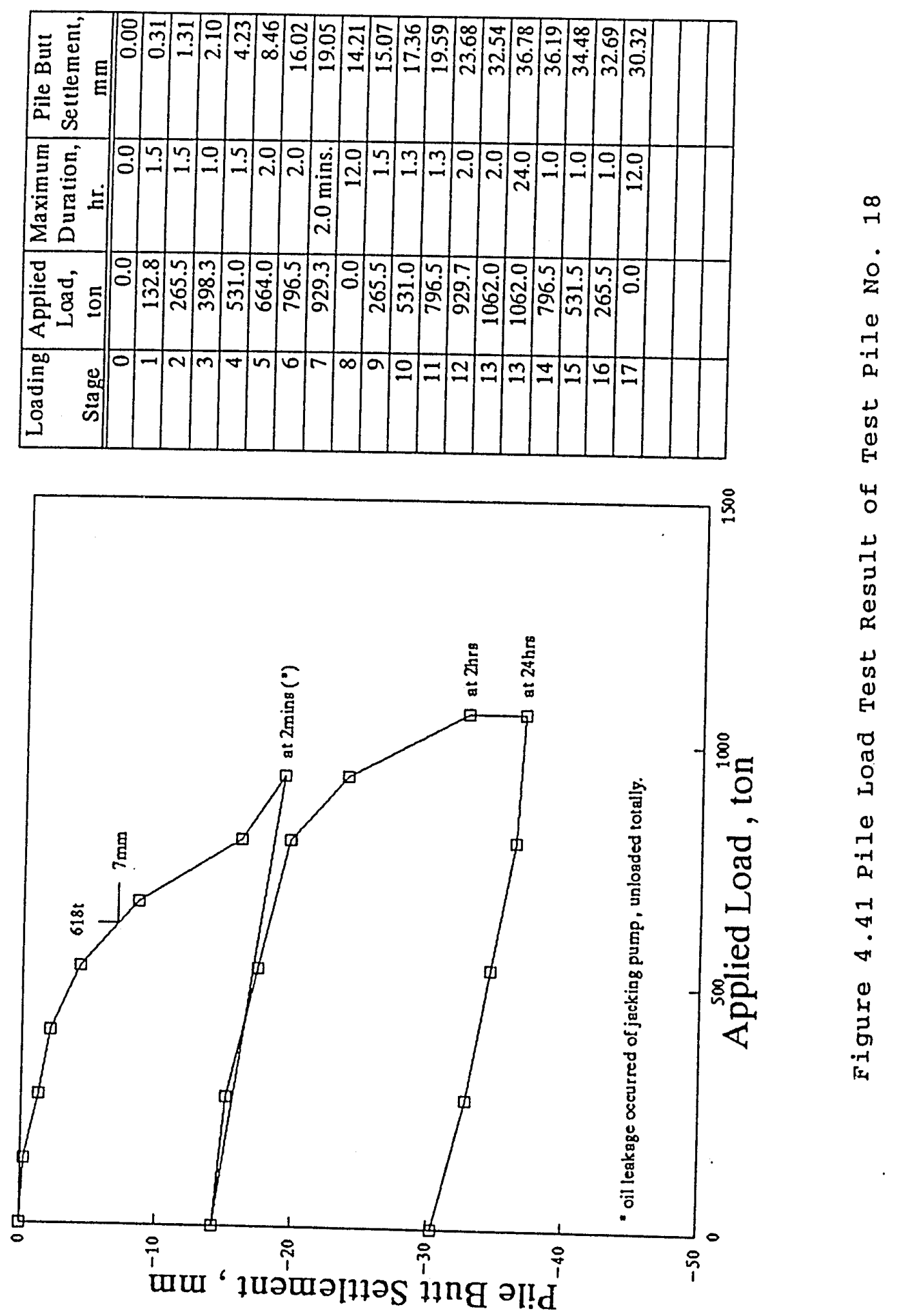
5.0 diameters center to center.

Loads were generally applied in eight equal increments up

to a maximum test load, which was twice the design load, and

then unloaded in four equal decrements, as shown in Figures 4.24

through 4.41 . Some minor deviation of loading stages occurred

as follows:

Pile No. 1 (Eigure 4.24): the first loading stage of 73.9 tons was carelessly missed.

Pile No. 4 (Figure 4.27): oil leakage occurred in the jacking pump twice at maximum loading stage. Both unloaded, repaired and reloaded again.

Pile No. 7 (Figure 4.30): the second and third unloading stages of 244.5 and 129.6 tons were carelessly missed.

Pile No. 8 (Figure 4.31): insufficient length of stroke-run of hydraulic jack occurred at maximum loading stage of 535.2 tons, the loading system was reloaded, reassembled and reloaded again.

Pile No. 13 (Figure 4.36): same as pile No. 8, maximum test load was 1080 tons. An additional loading cycle was applied to see if excessive settlement still occurred.

Pile No. 15 (Figure 4.38): same as pile No. 8, but occurred at 
the seventh loading stage of 738.5

tons.

Pile No. 18 (Figure 4.41): oil leakage occurred at the jacking pump at seventh loading stage of 929.3 tons, unloaded totally, repaired and reloaded again.

Detailed graphical presentations of the load-settlement curves for the pile testings are shown also in Figures 4.24 through 4.41 .

\subsection{Analysis of Data}

The test data of eighteen pile tests are analyzed by comparing the developed shaft frictions determined from the pile test results with the computed values.

For the shaft friction in the clay layer, it is computed based on the two empirical approaches that unit shaft friction of the pile, $f$, is a function of cone friction, $f s$, in the expression as follows:

$$
\begin{array}{ll}
\mathrm{f} & =\alpha^{\prime} \text { fs and } \\
\mathrm{f} & =\mathrm{m} \text { fs }
\end{array}
$$

where both $\alpha$ and $m$ factors vary with cone friction, decreasing 
with an increase in cone friction, as shown in Figures 2.2 and 2.3 which are suggested by Schmertmann (1978) and Tumay et. al. (1981), respectively.

When granular soil is encountered, the relevant shaft friction is computed using the empirical formula suggested by Meyerhof (1976) as:

$\begin{array}{ll}f\left(\mathrm{~T} / \mathrm{m}^{2}\right)= & 0.1 \mathrm{~N} \\ \text { where } \mathrm{N} & =\quad \begin{array}{l}\text { average value of standard Penetration } \\ \text { Test resistance }\end{array}\end{array}$

The limiting value for shaft friction in granular soils of $12 \mathrm{~T} / \mathrm{m}^{2}$ usually used by Dutch engineers (Schmertmann, 1978) is applied in the computation.

Tables 4.1 through 4.18 are the computations of the shaft frictions of the eighteen test piles, i.e., piles number 1 to 18. On these tables, the soil parameters used are referred to Figures 4.4 through 4.21 , respectively, which are based on the nearest reference boreholes and CPT data from each test pile, and are also based on the construction records of each test pile. For the soil type abbreviations, refer to Table 3.1 . The determined maximum shaft friction of each test pile is defined from the relevant load versus butt settlement curve (Figures 4.24 through 4.41 ). That is, the load at butt settlement equals to $7.0 \mathrm{~mm}$. 


\subsection{Discussion of Results}

Table 4.19 summarizes the analysis of shaft friction of piles by comparing the computed shaft frictions using equations suggested by Schmertmann (1978) and by Tumay et. al. (1981) and the shaft friction determined from load testings. The computed shaft frictions using equation suggested by schmertmann are found to be 19 508 lower than the shaft friction determined from load testings, while the computed shaft frictions using equation suggested by Tumay et. al., are found to agree reasonably well within 1 228 (mostly under 188) from the shaft frictions determined from load testing.

The difference of the two computed shaft frictions is due to the significant difference of $\alpha^{\prime}$ and $m$ factors for cone friction, fs, lower than $0.36 \mathrm{~kg} / \mathrm{cm}^{2}$, as shown in Figure 4.42 . The fs values for the top $20.0 \mathrm{~m}$ depth of cohesive soils, where the eighteen test piles located, are generally lower than 0.36 $\mathrm{kg} / \mathrm{cm}^{2}$.

As a reference, Table 4.19 shows also the percentage of the calculated granular frictions, which were calculated using equation suggested by Meyerhof (1976), from maximum calculated frictions. It suggests that the amount of the granular portions does not significantly influence the analysis of the data, and even if, would still be on the safe side. 


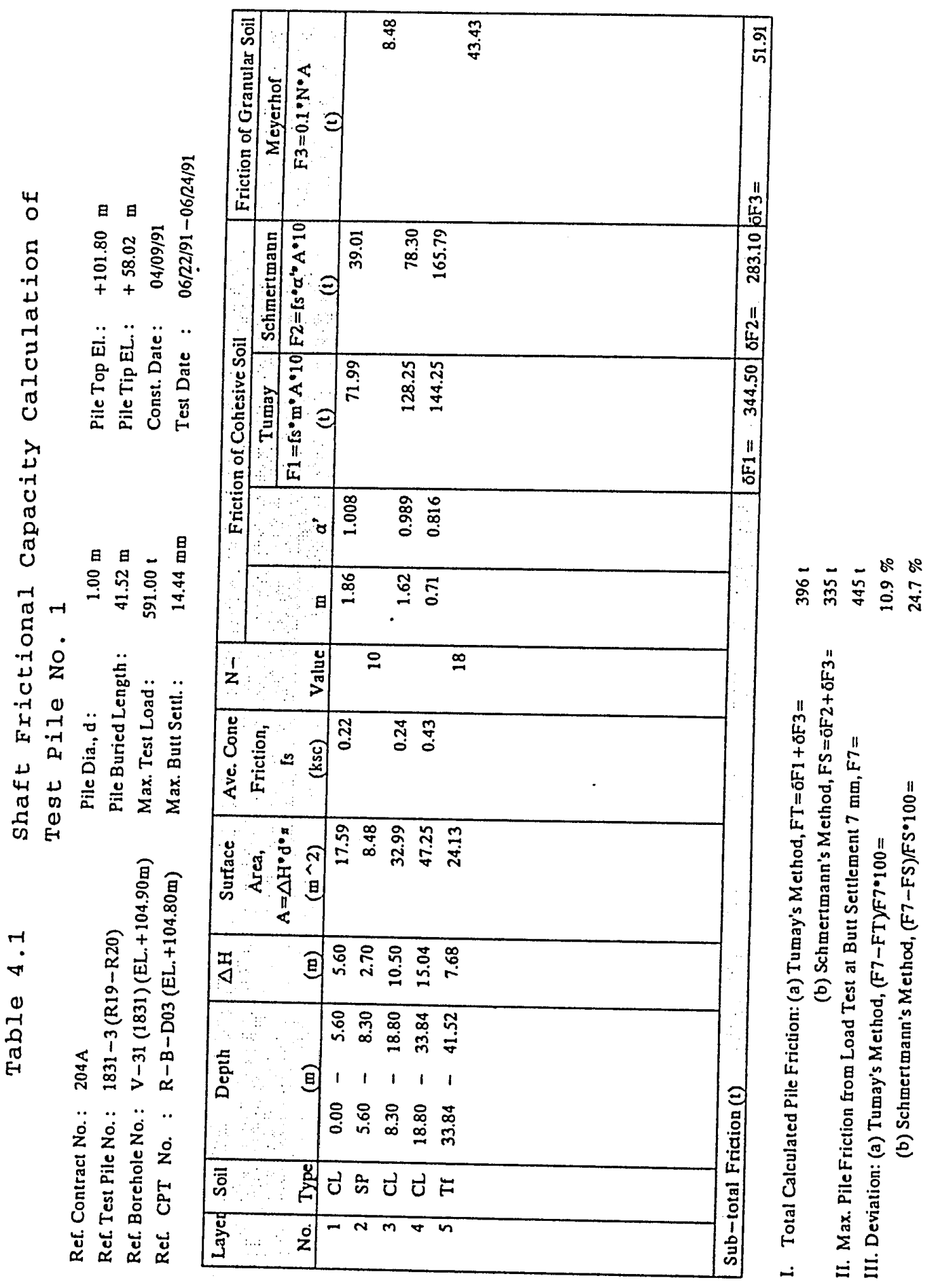




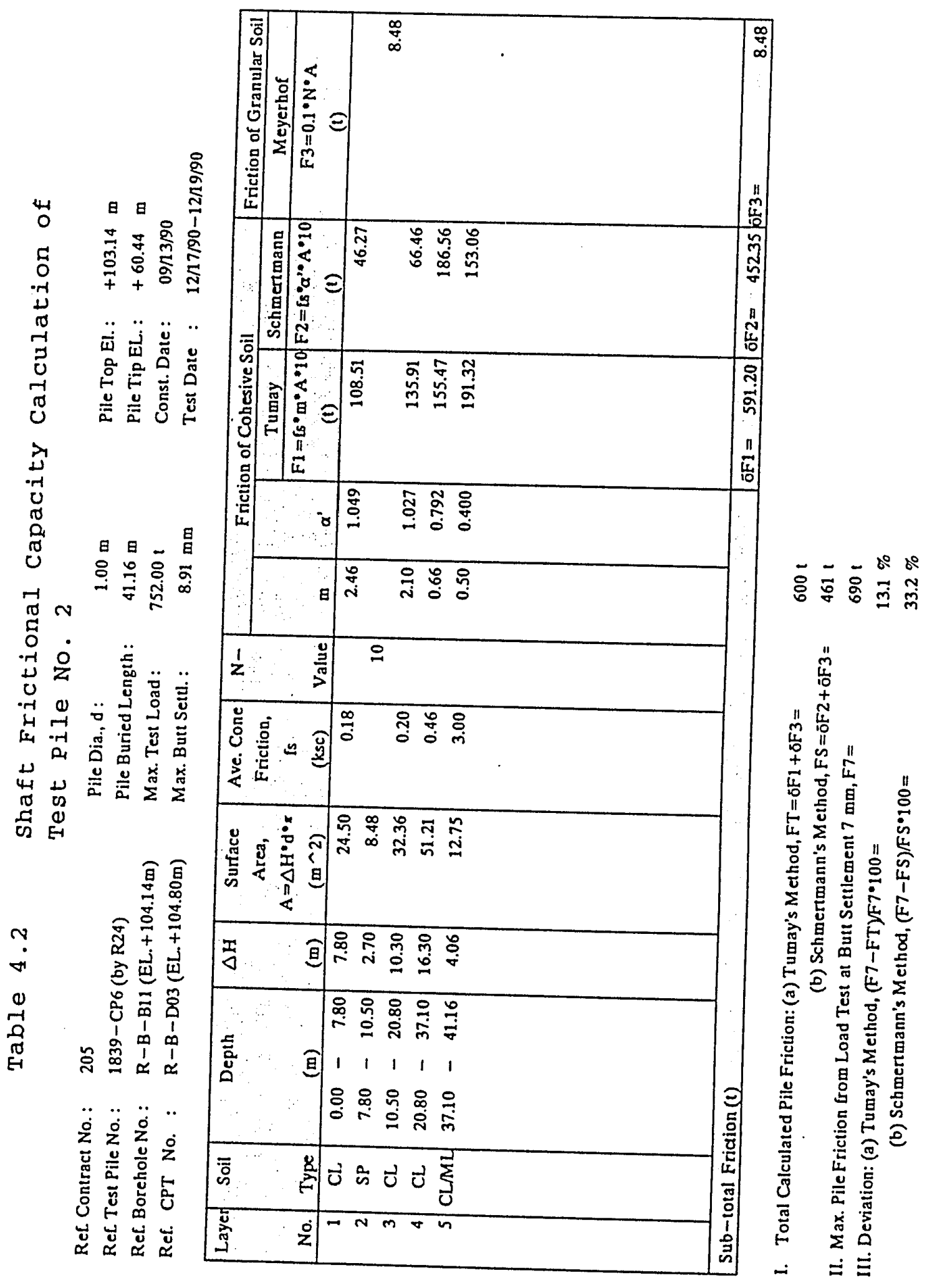




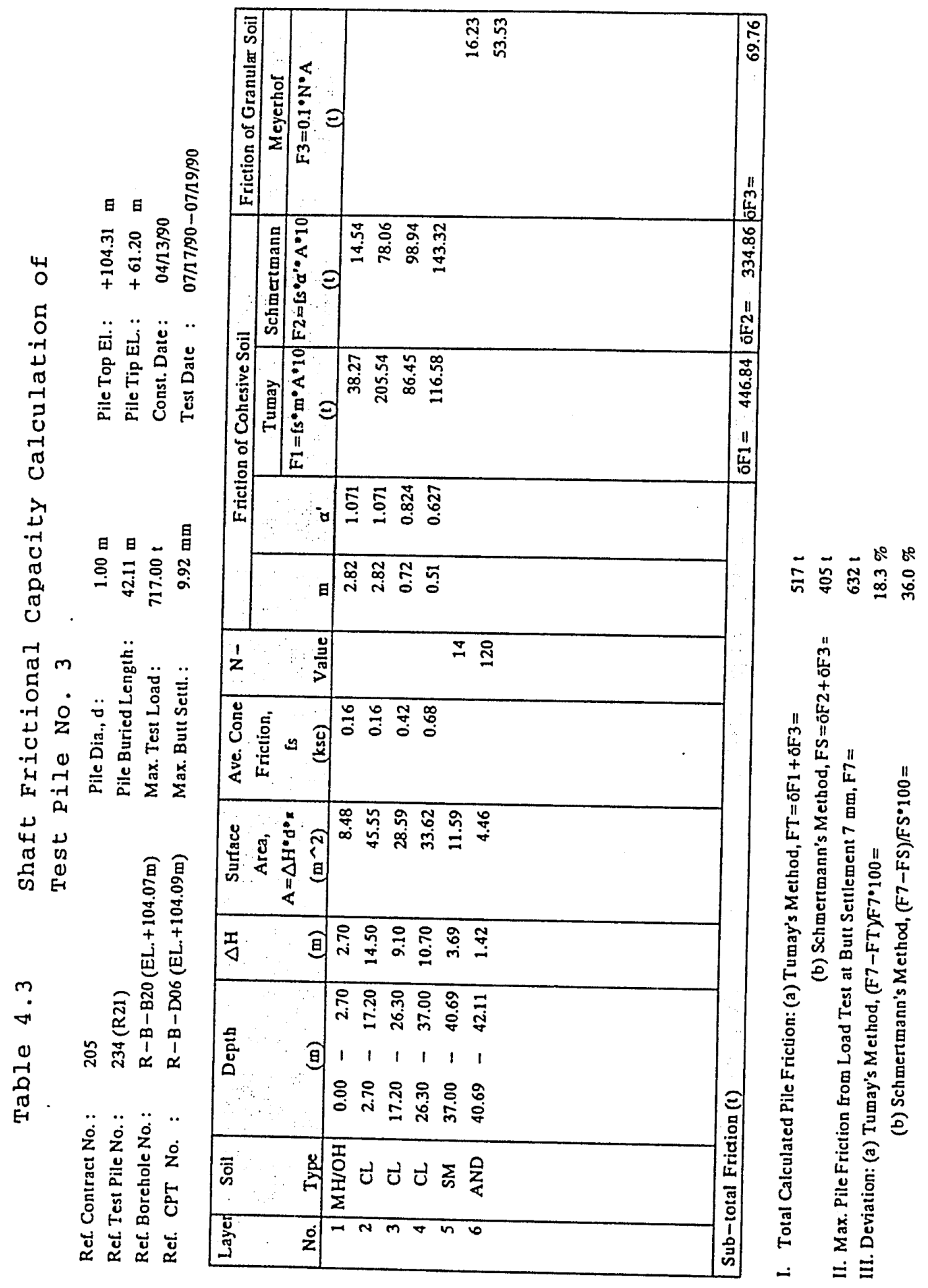




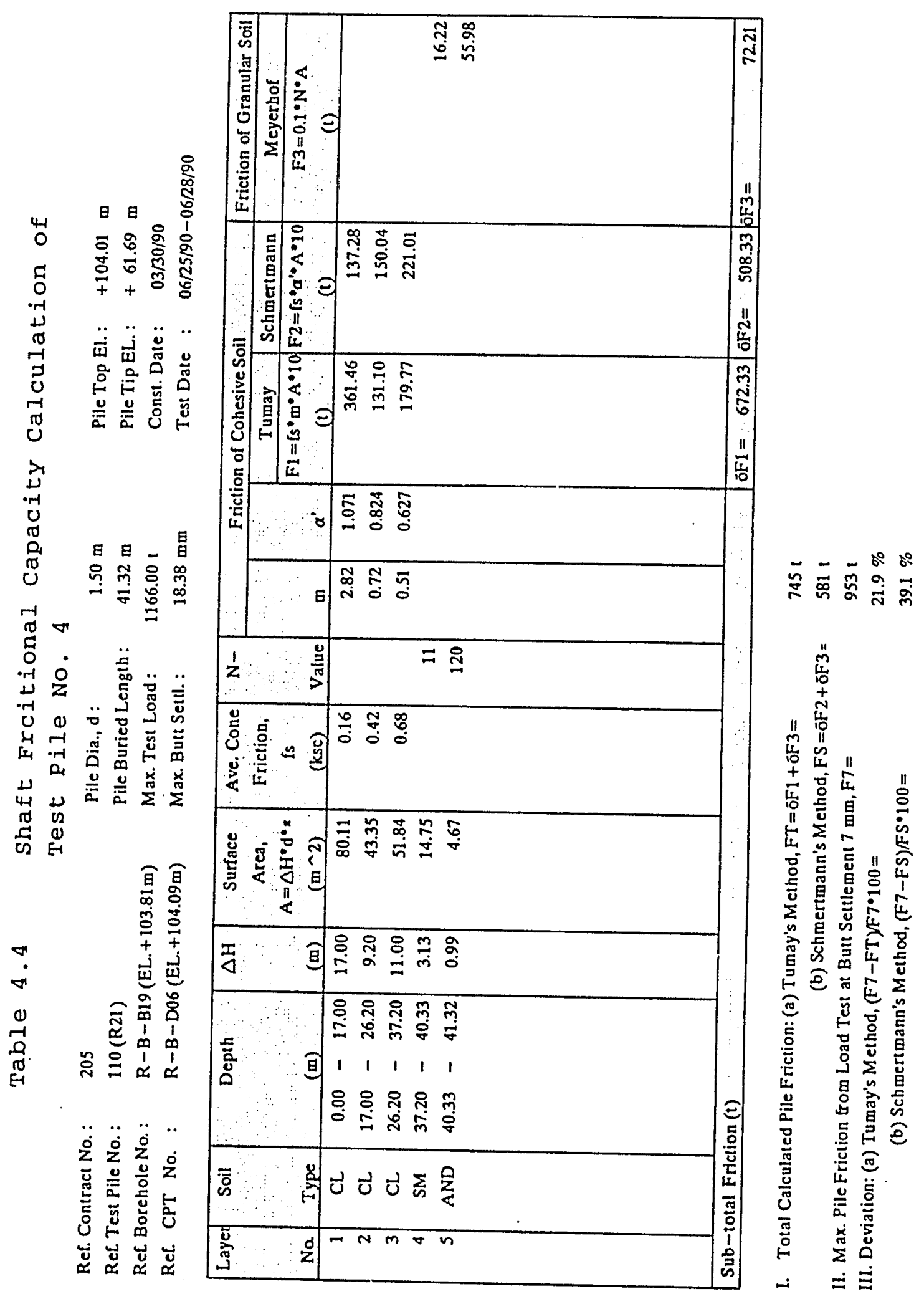




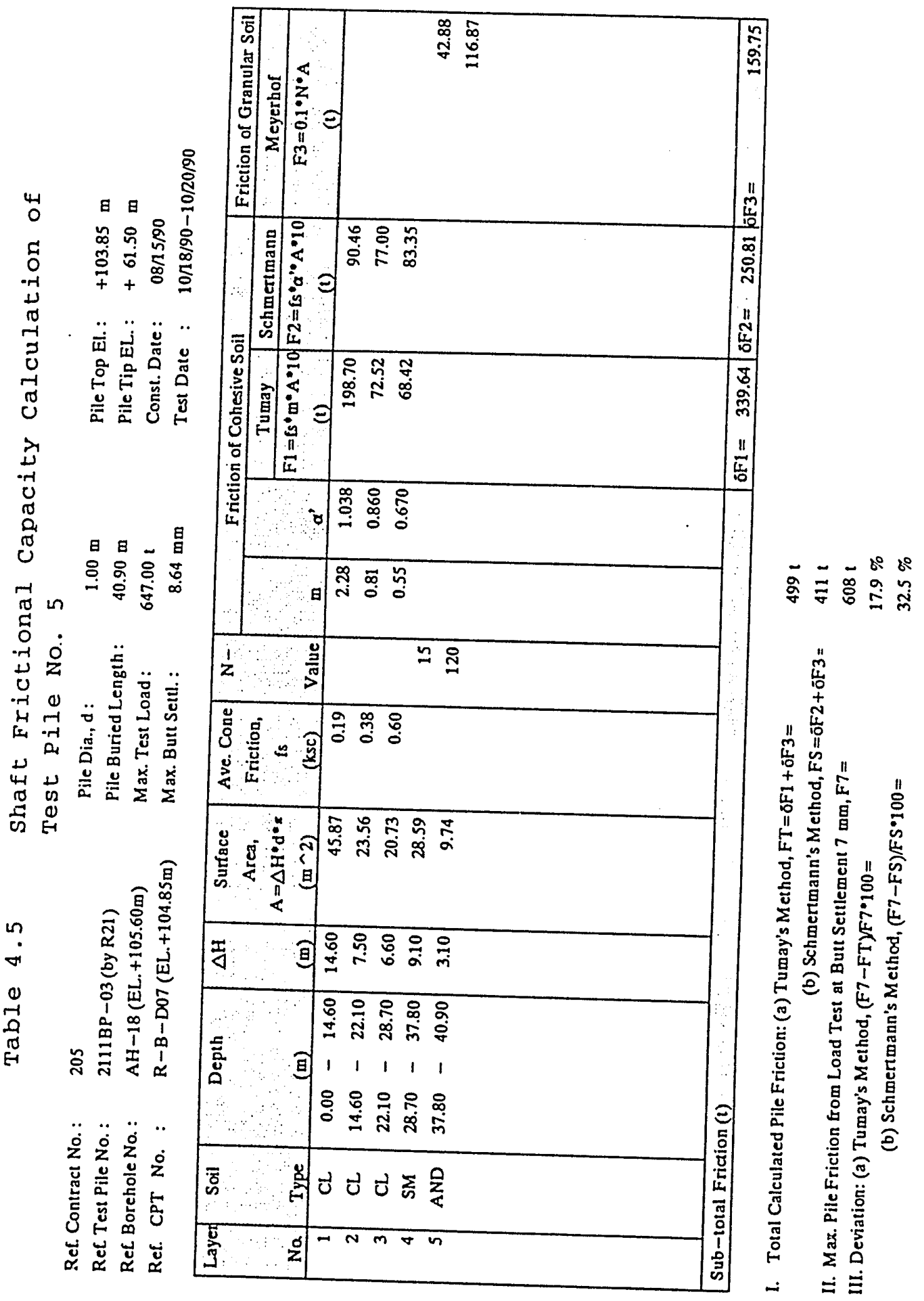




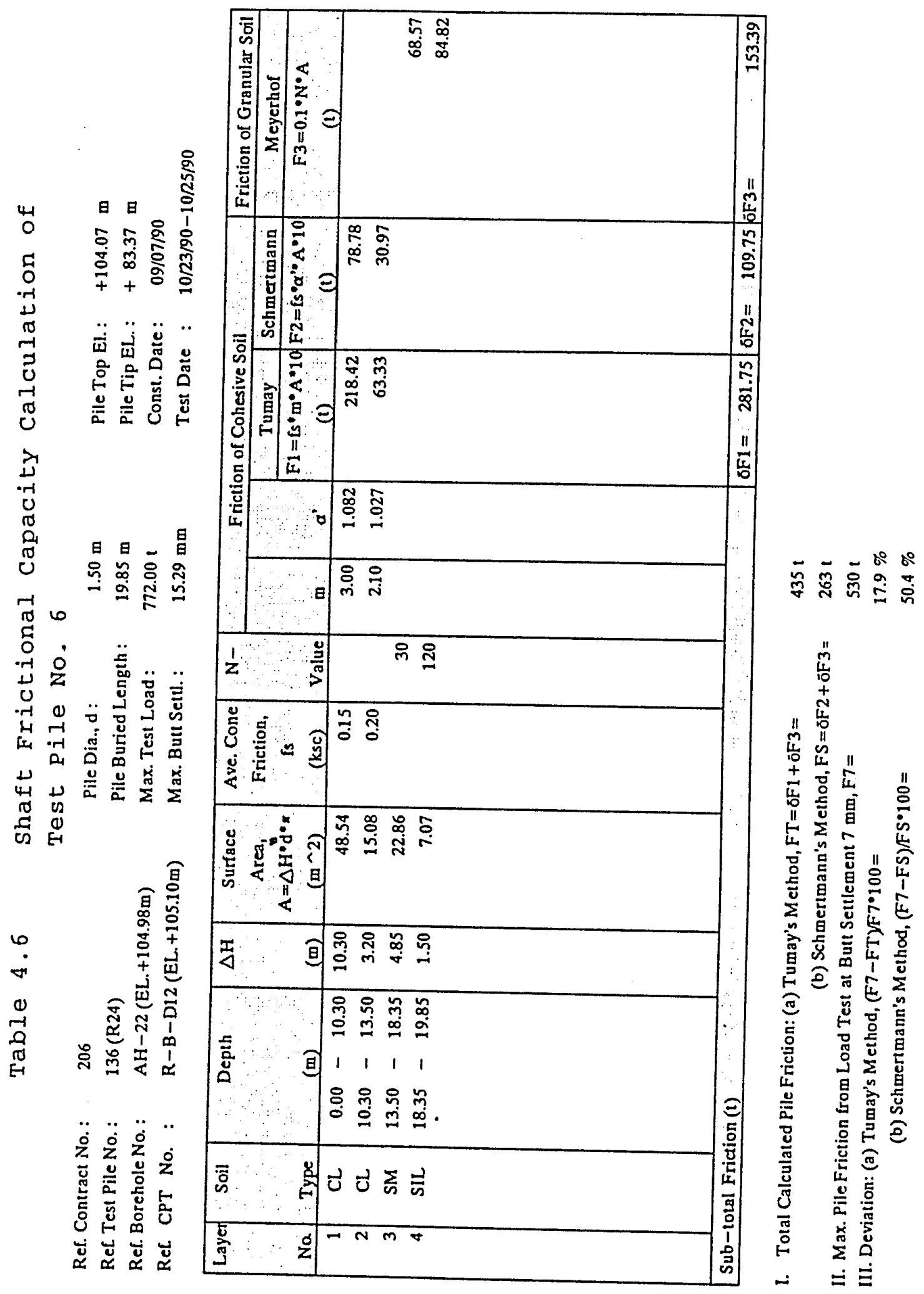




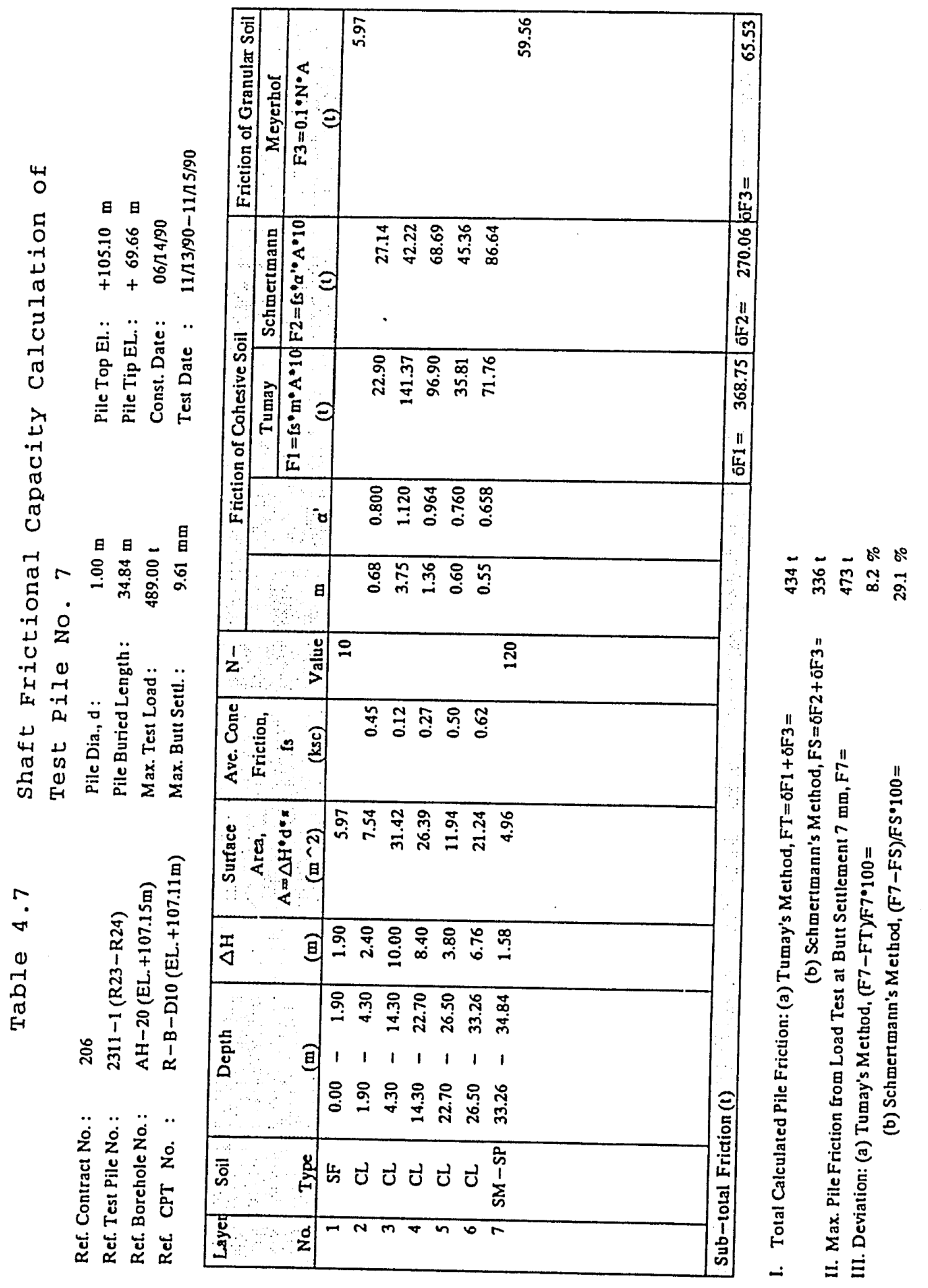




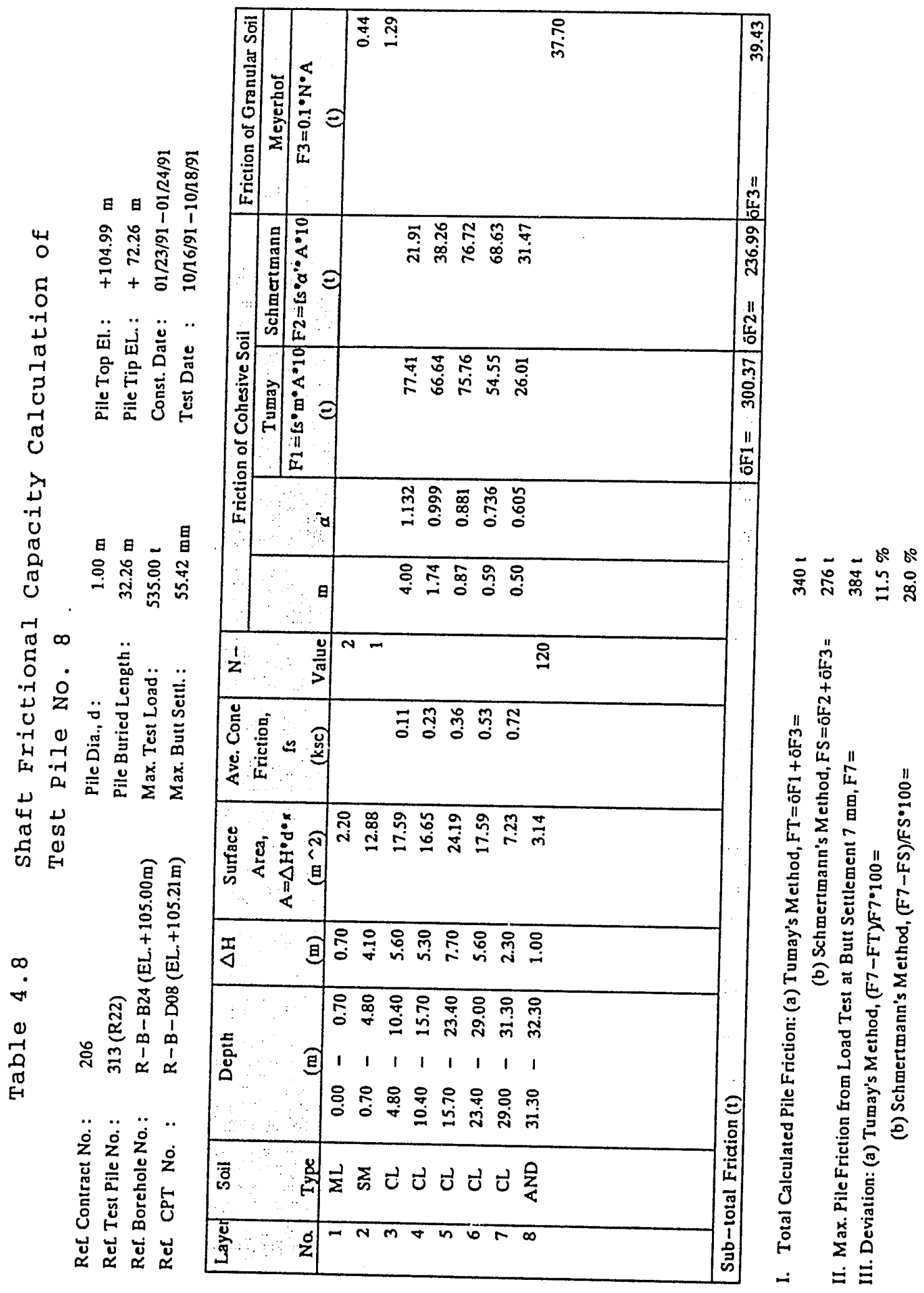




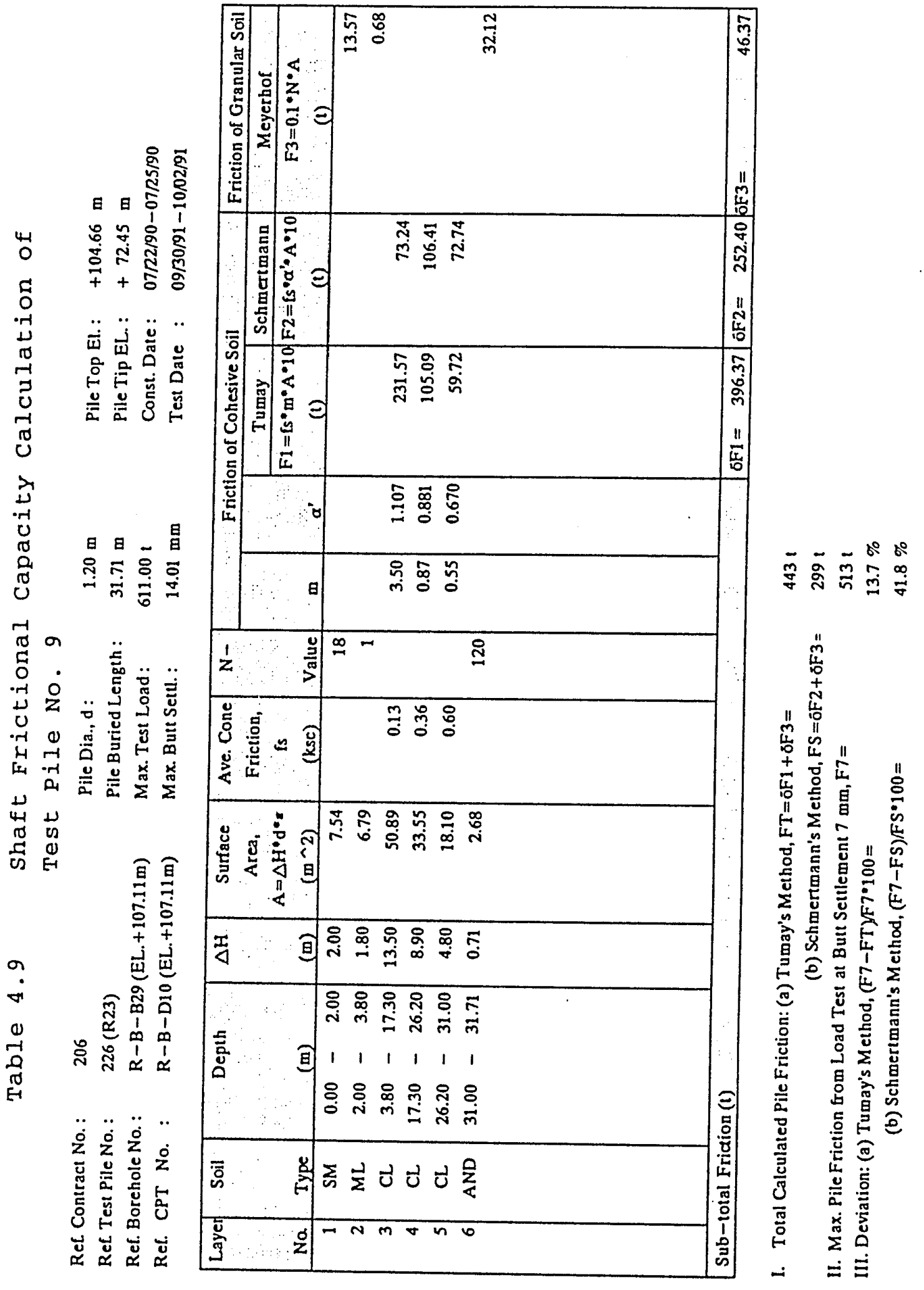




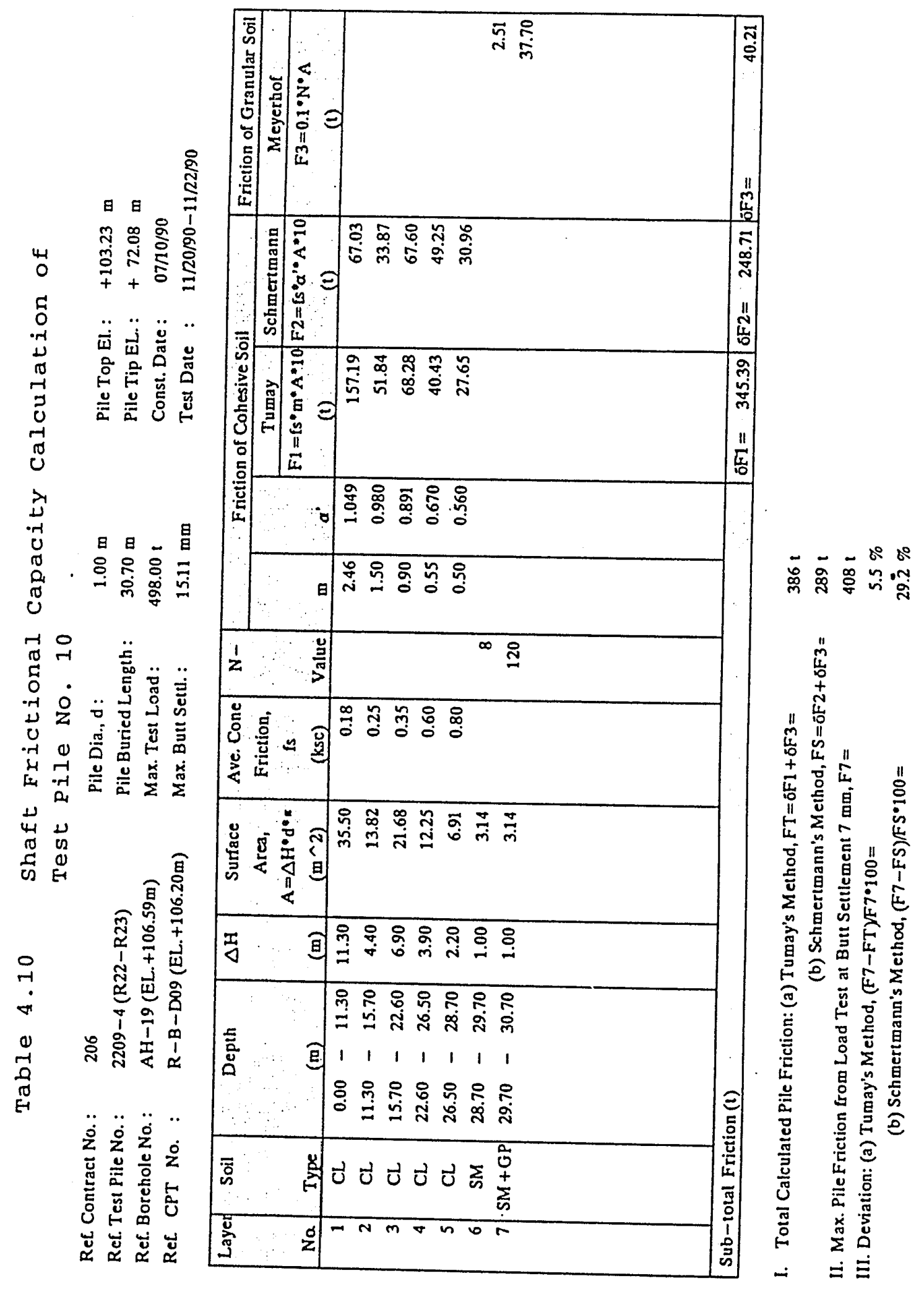




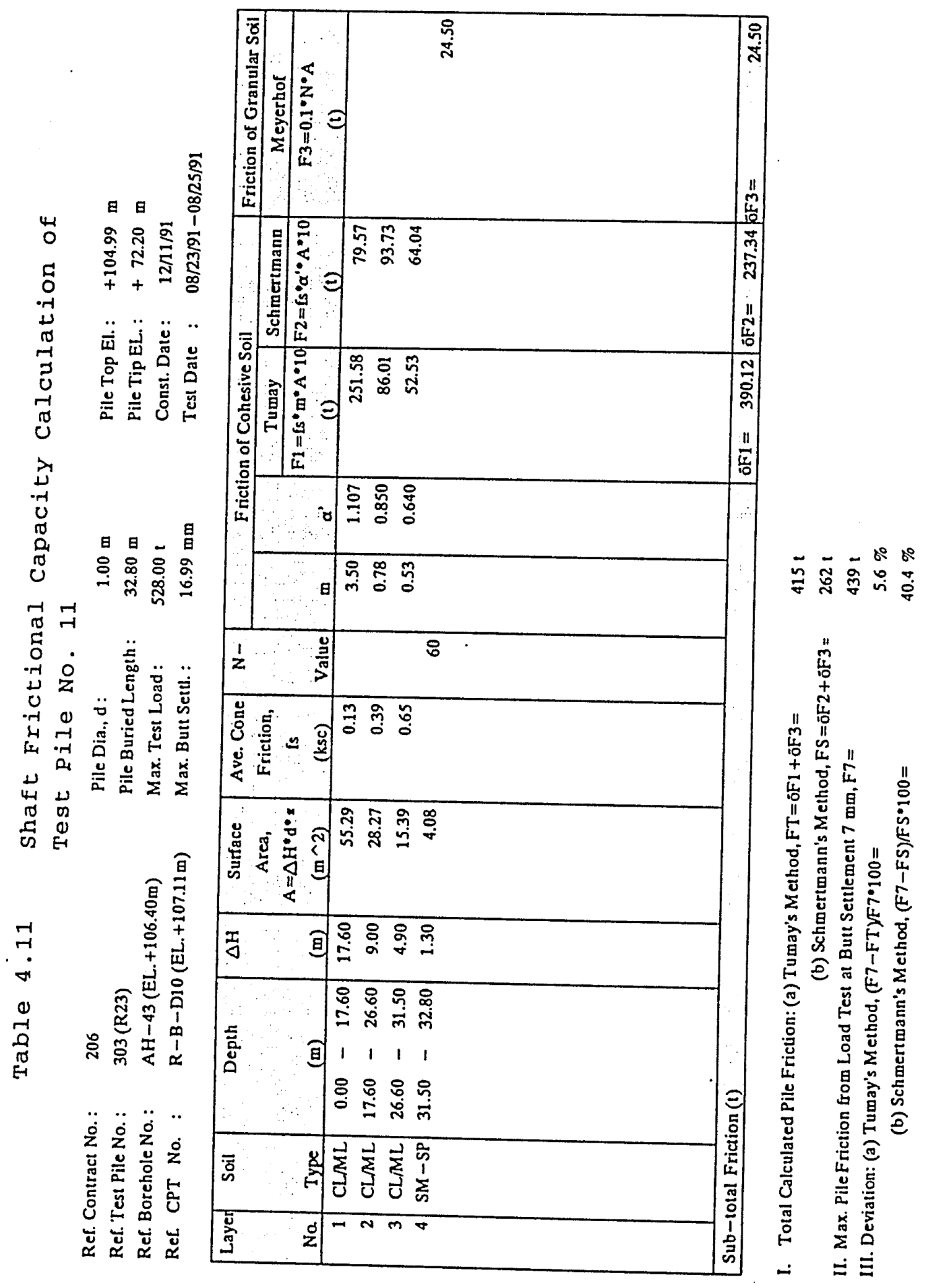




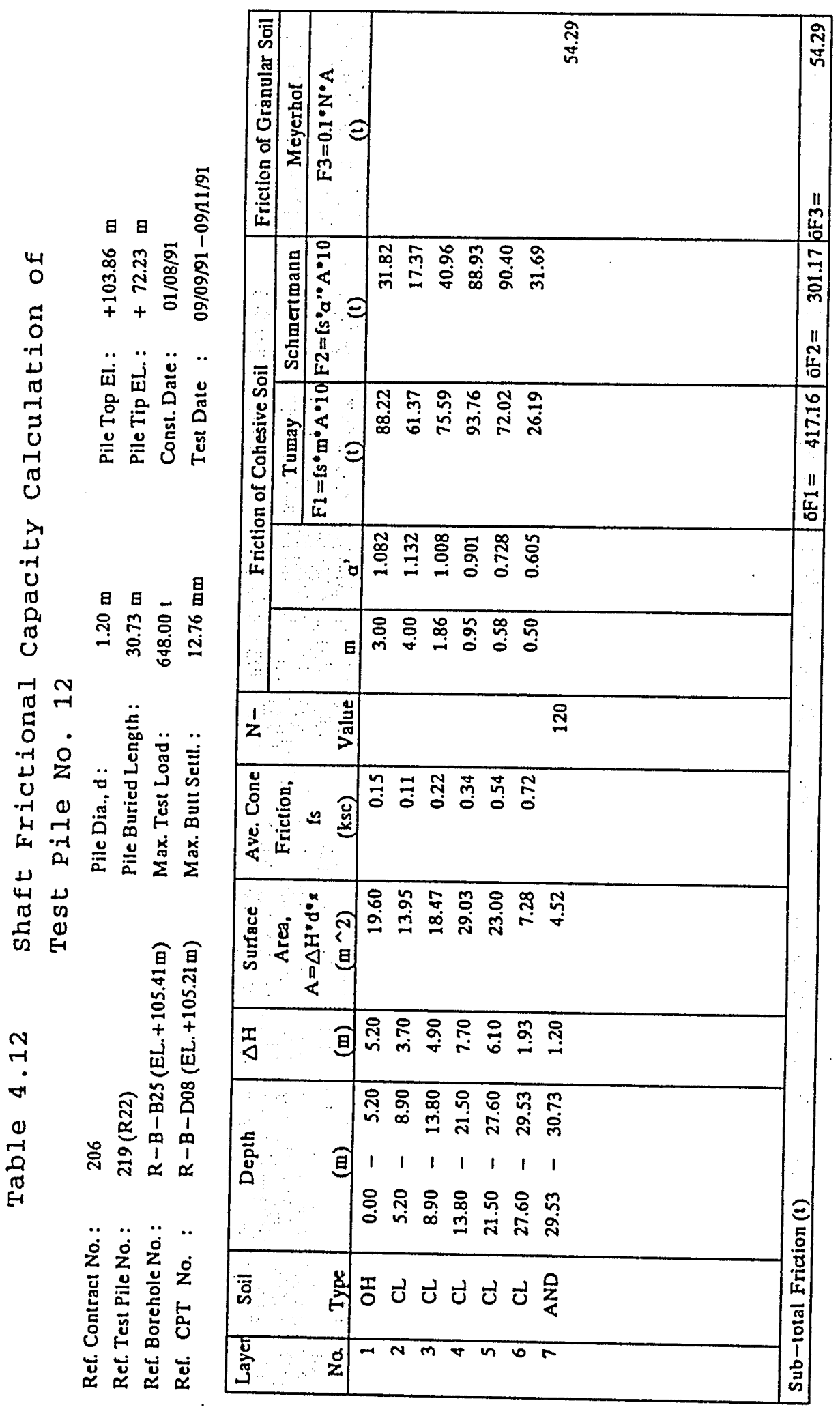

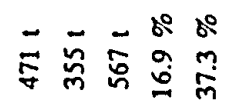

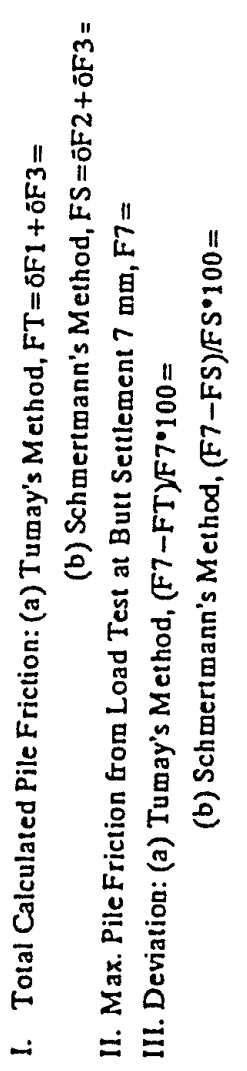




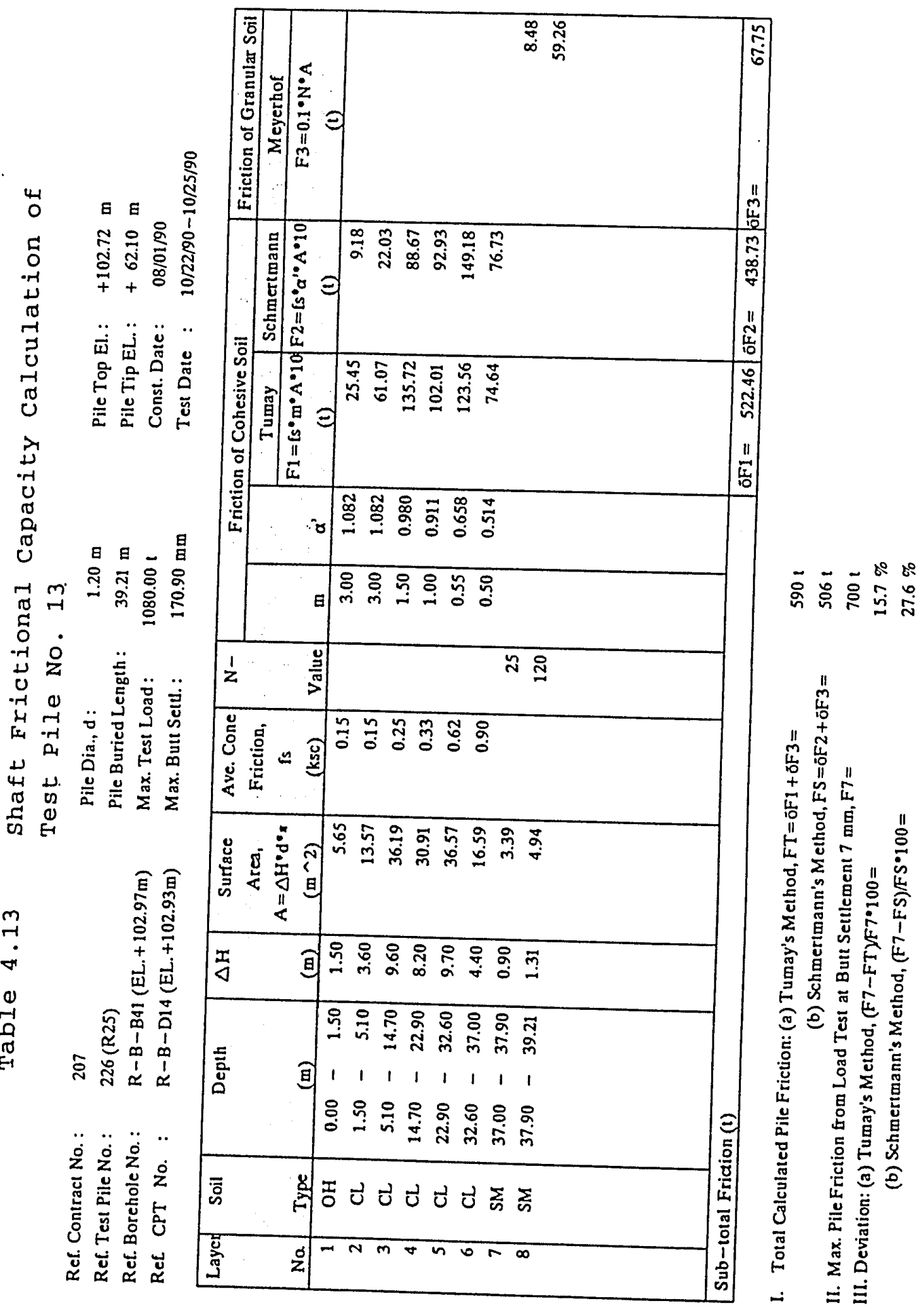




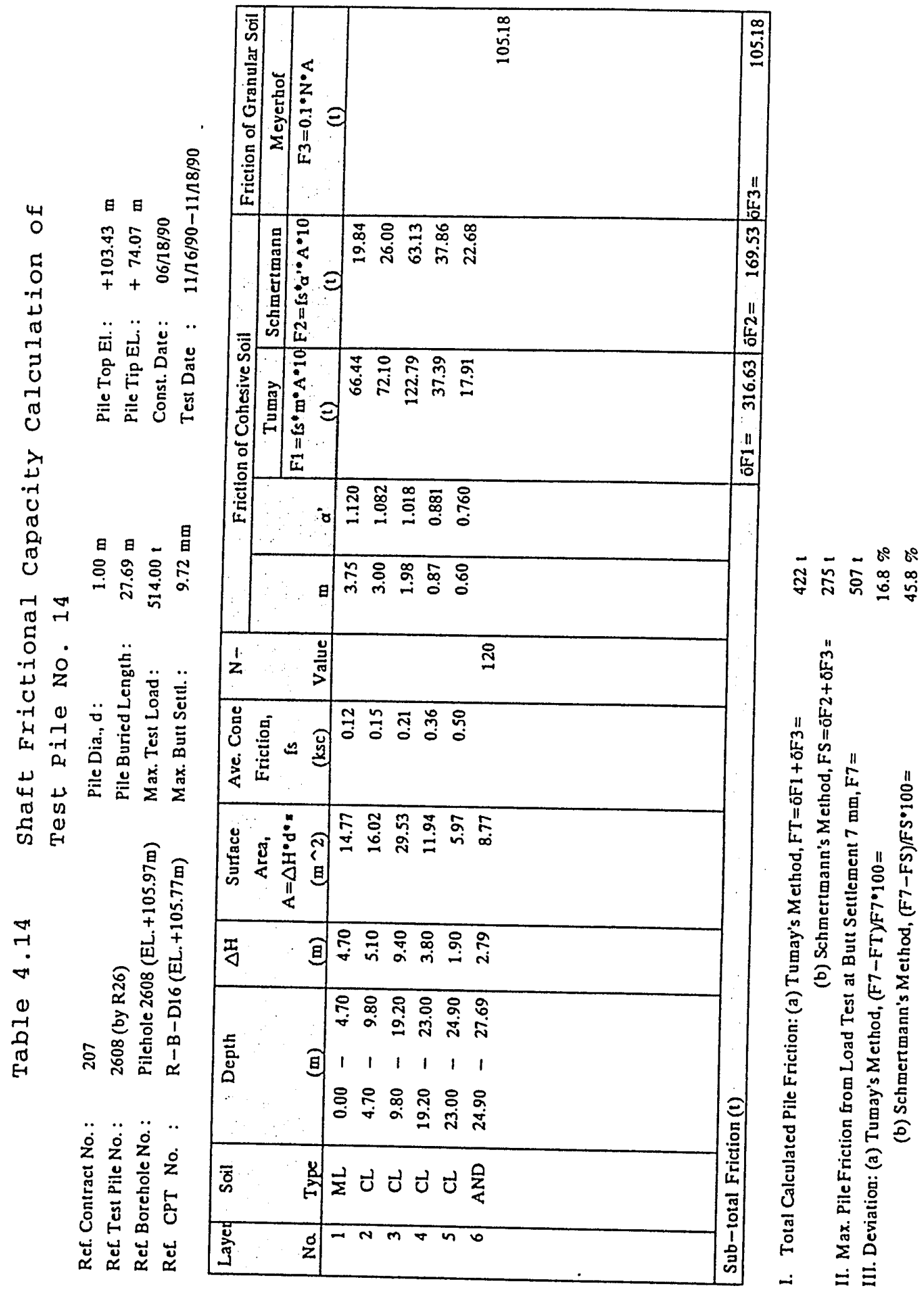




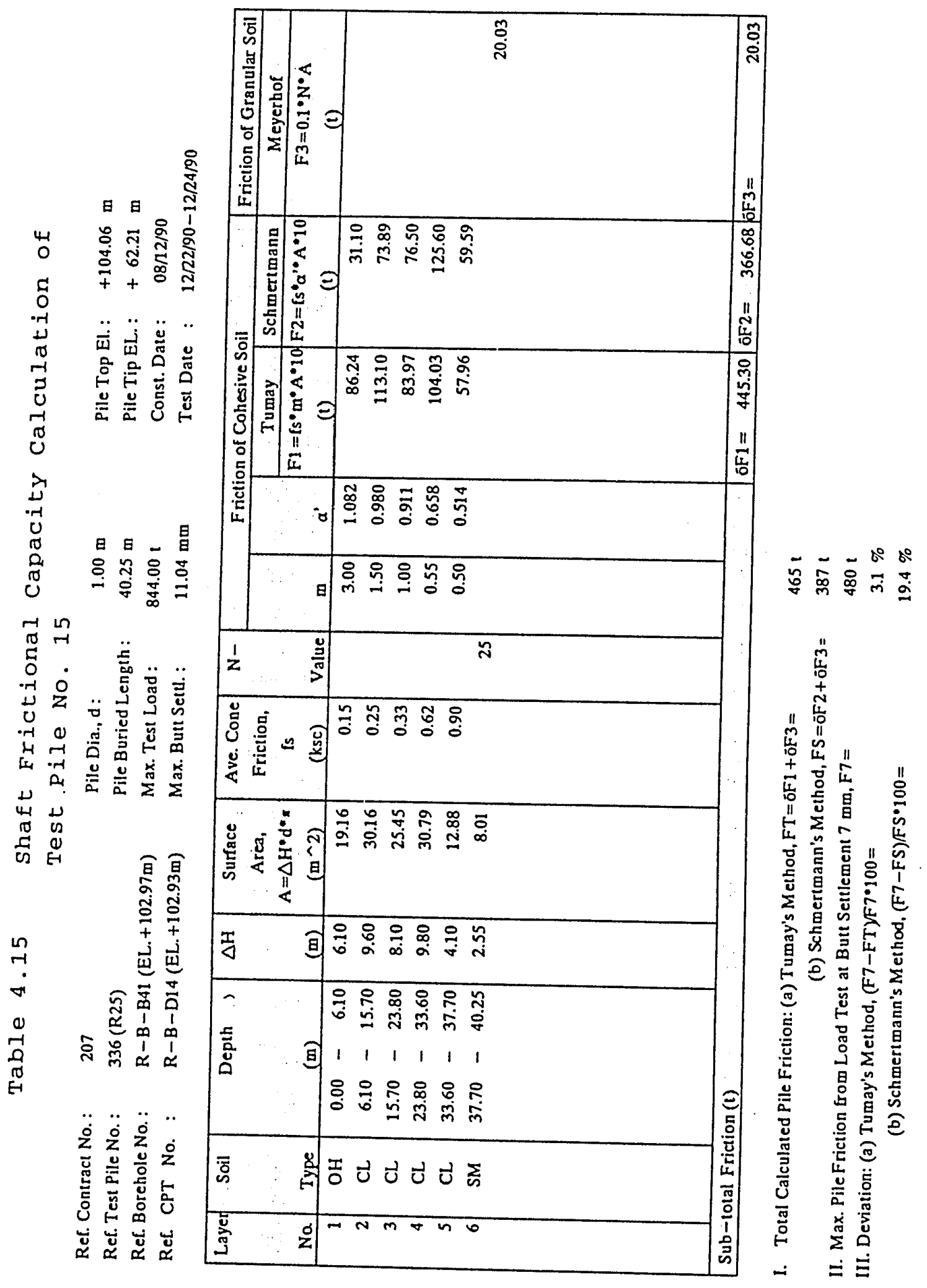




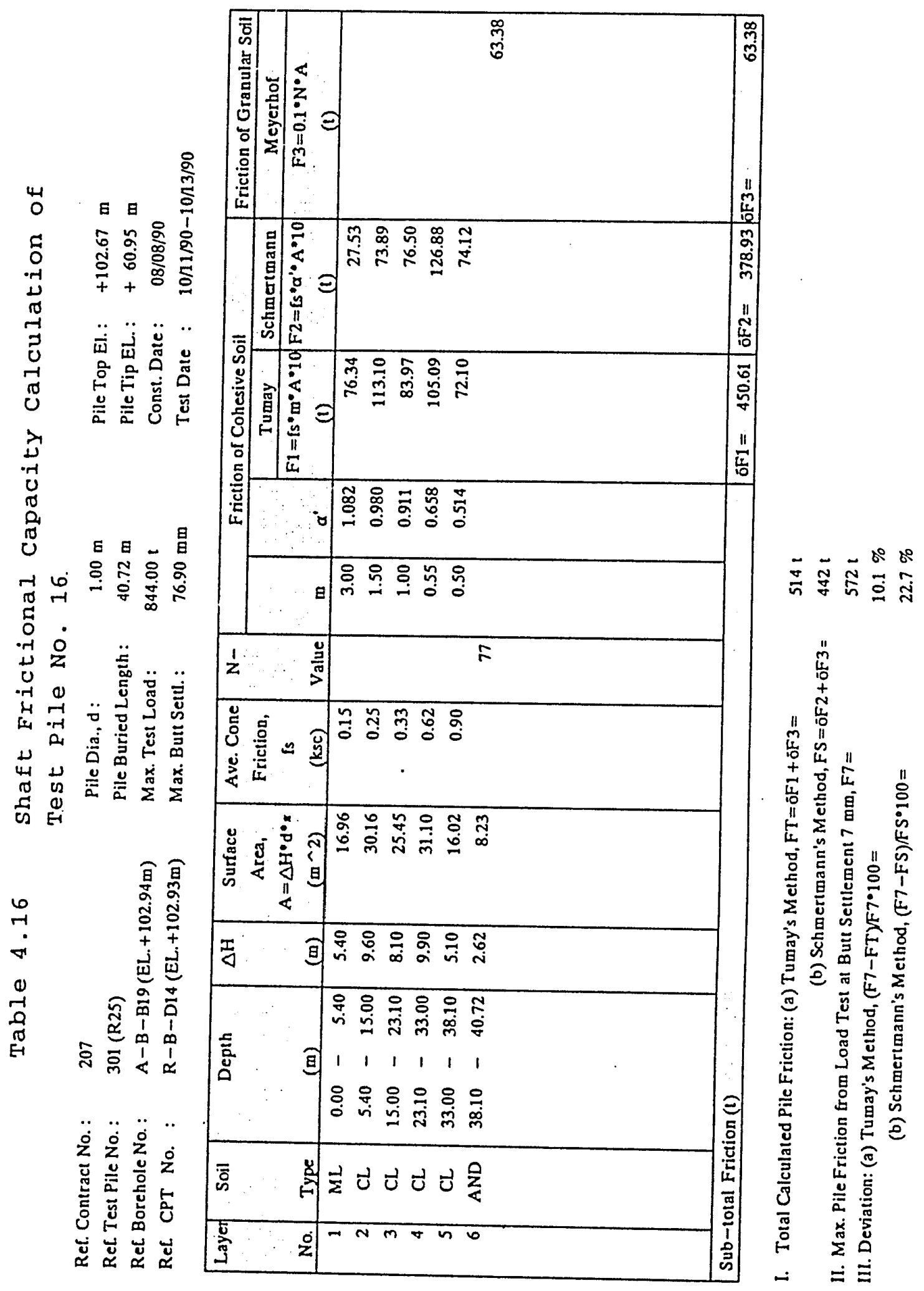




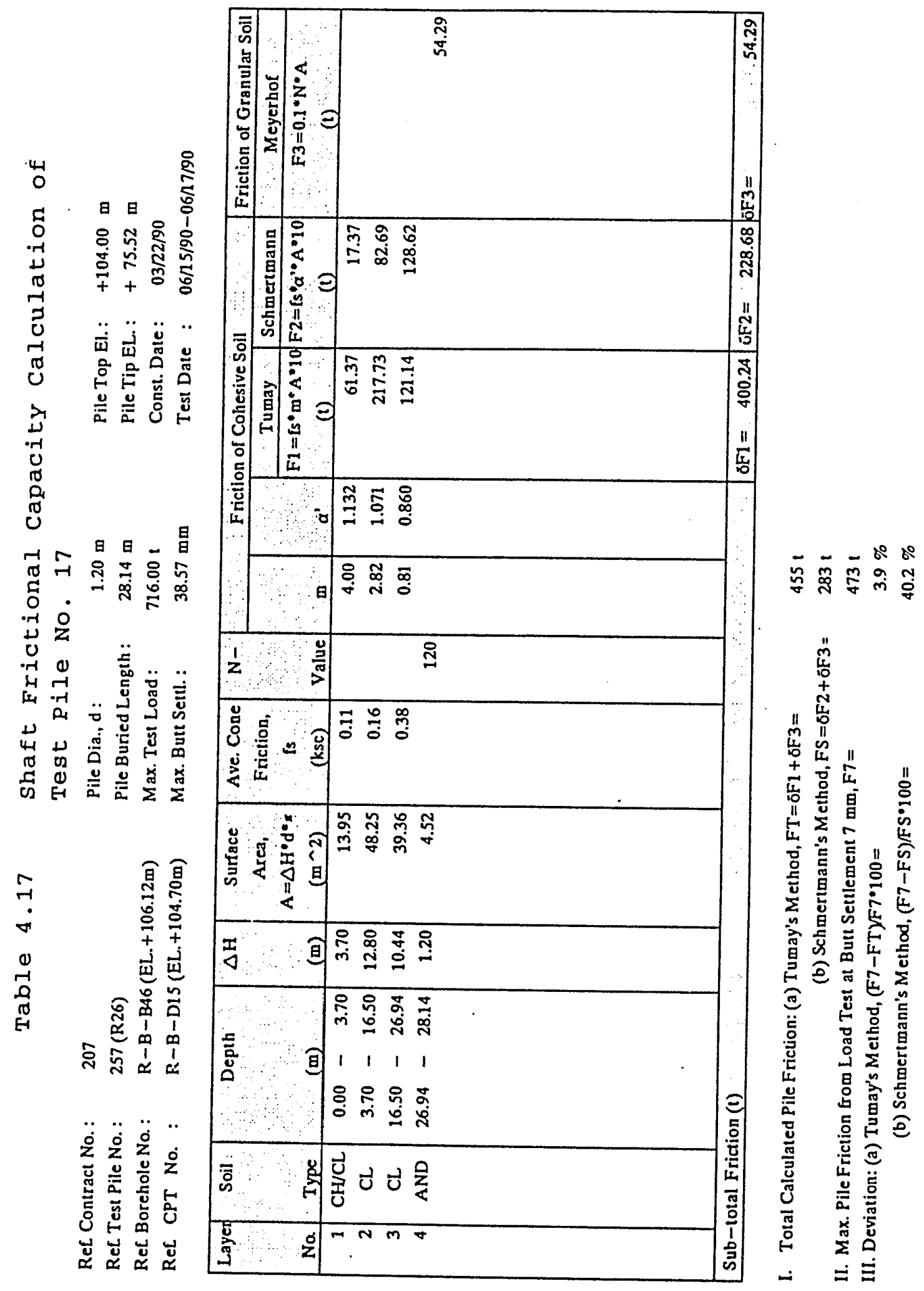


109

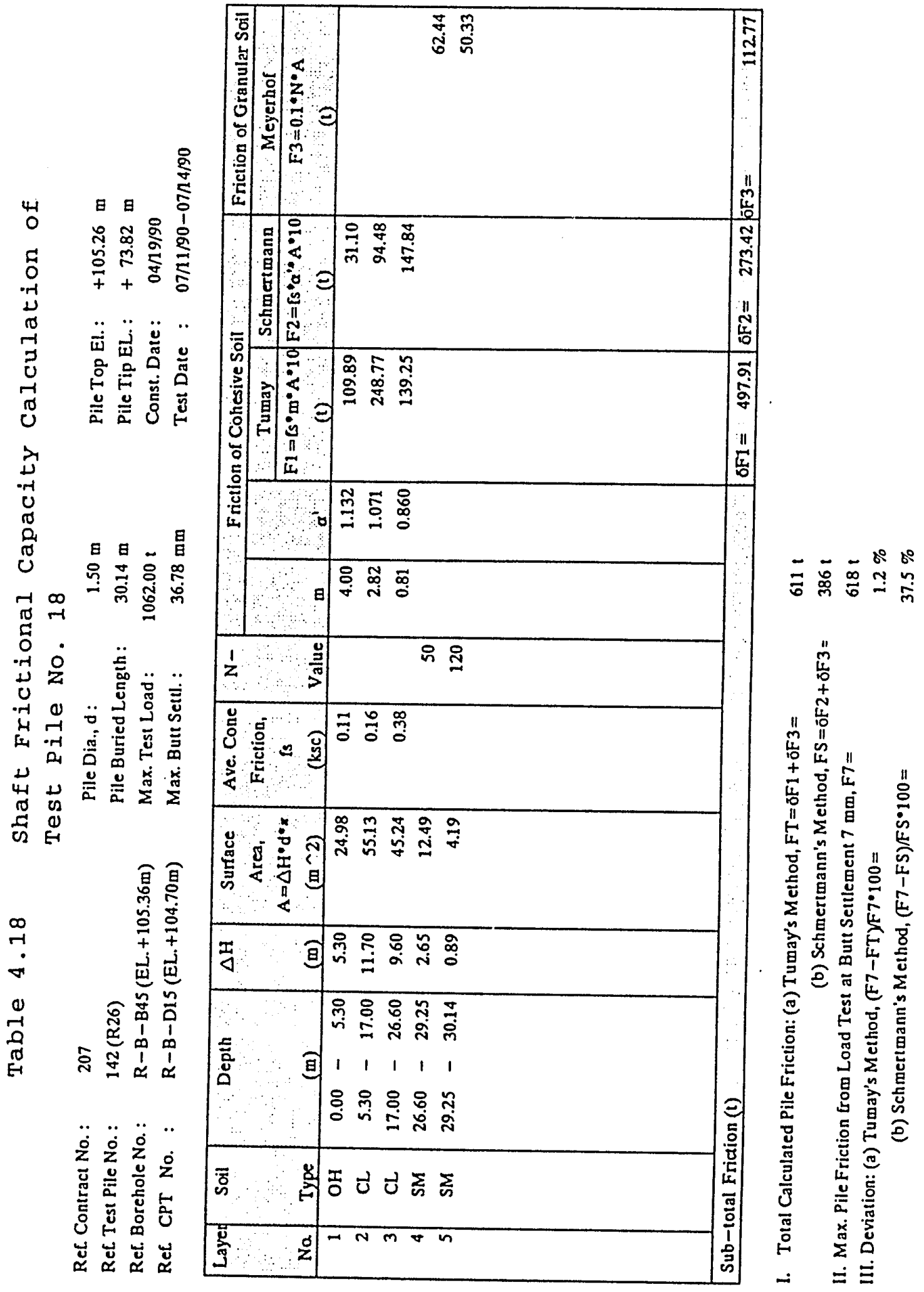




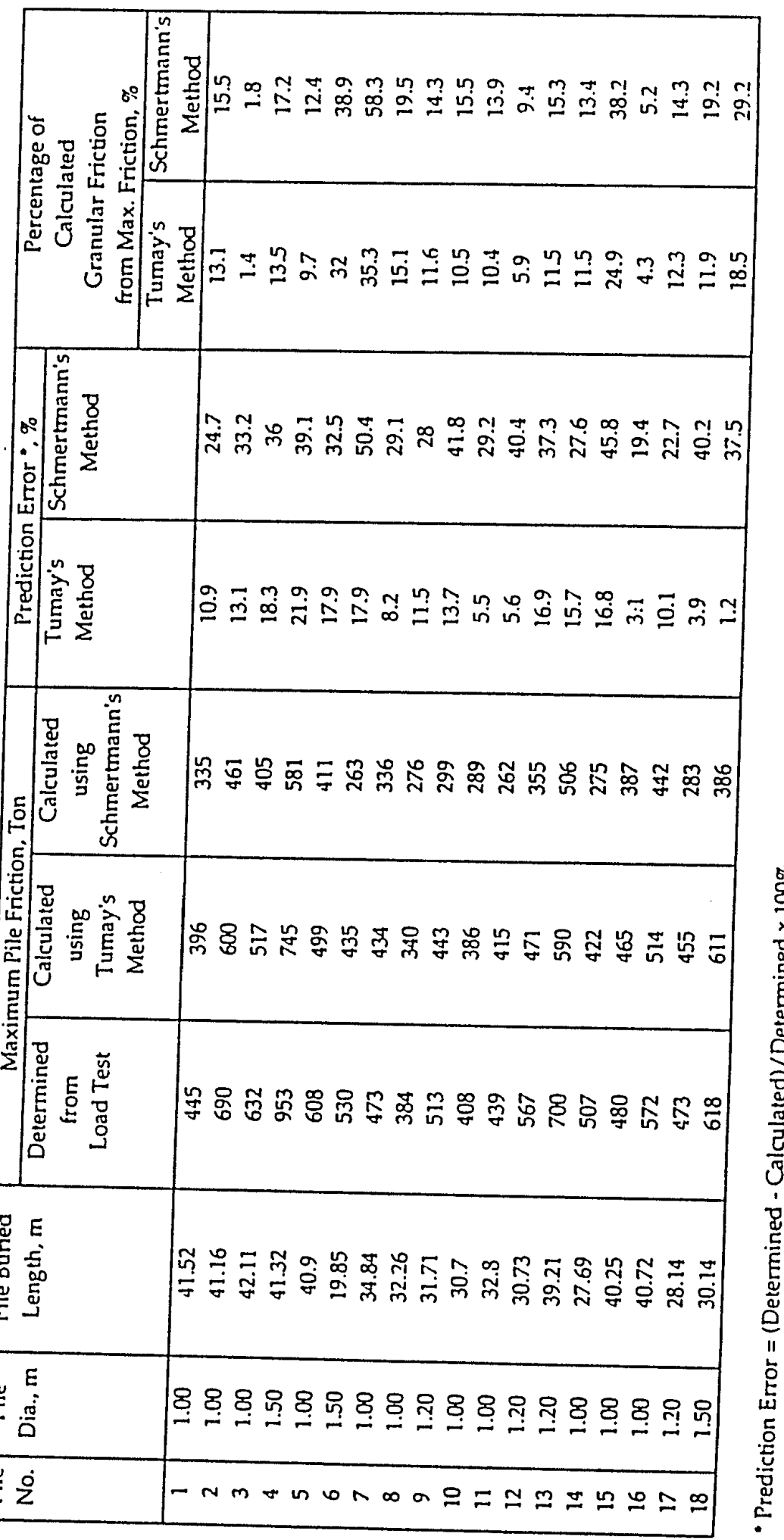




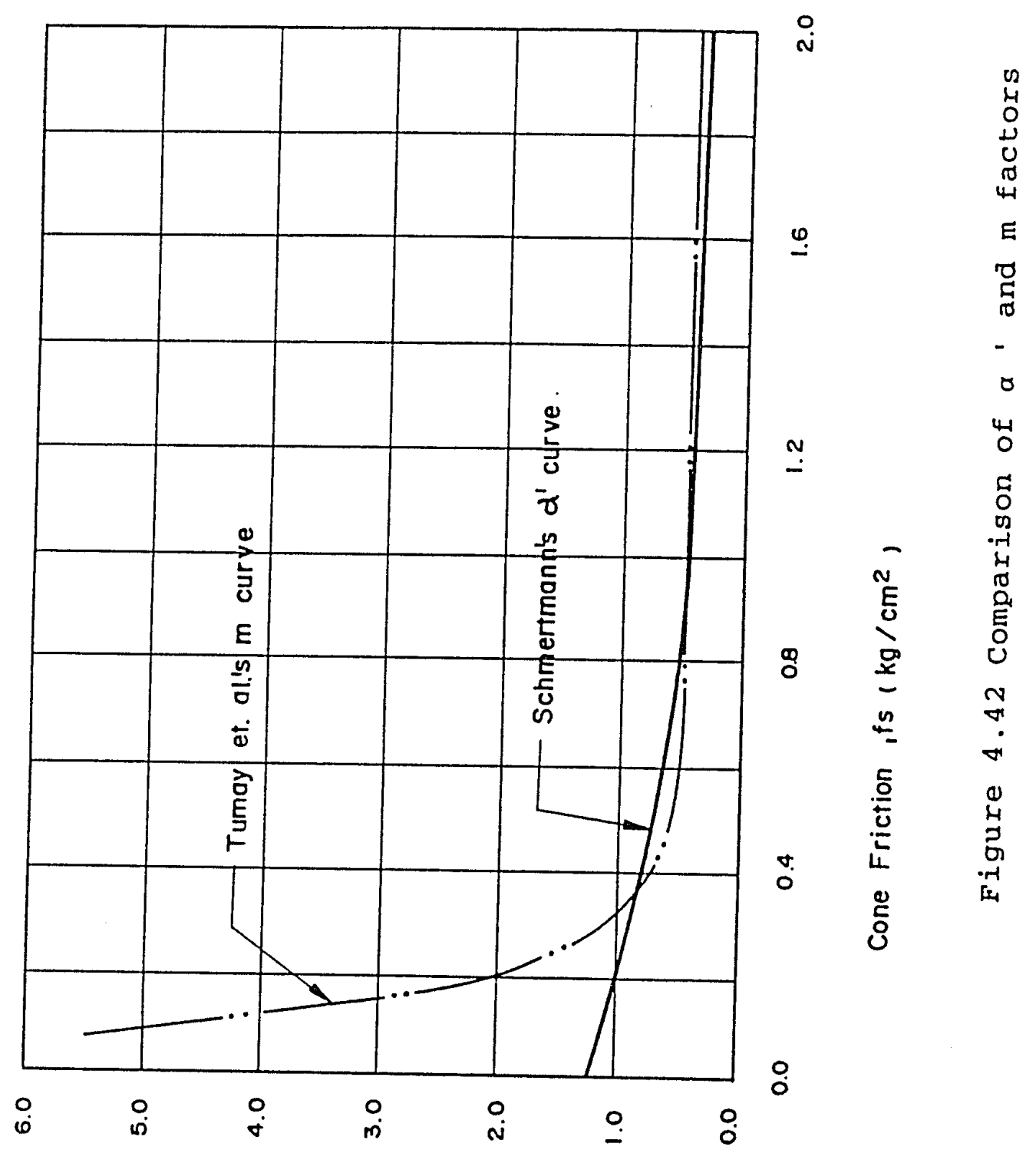

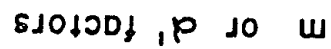




\section{CHAPTER $v$}

\section{CONCLUSIONS}

1. The available instrumented test piles data back up that the maximum shaft friction of a test pile in cohesive soils can be defined from its load versus butt settlement curve, that is, the load at butt settlement equals to $7.0 \mathrm{~mm}$.

2. The analysis of the results of eighteen pile load tests located within the tributary area of the Keelung River, which predominately consists of fine grained silts and clays, suggests that the present state-of-the art methods for utilizing Cone Penetration Test (CPT) data for maximum shaft friction prediction in cohesive soils agree reasonably well when using method suggested by Tumay et. al. (1981), i.e., within 1-228 with mostly under 188 and on the safe side, compared with the observed values from load testings; but the method suggested by Schmertmann (1978) tends to underestimate the load carrying ability (up to 508) of the piles in this region. 
3. The difference of the two computed shaft frictions is due to the significant difference of $\alpha^{\prime}$ and $m$ factors for cone friction lower than $0.36 \mathrm{~kg} / \mathrm{cm}^{2}$ as shown in Figure 4.42 , where the $m$ factor is higher than the $\alpha^{\prime}$ factor.

4. In general, the interpretive procedure using CPT data has the following advantages that seem to warrant its application: a. The procedure currently requires only the most popular insitu tests data, i.e., Cone Penetration Test (CPT) and Standard Penetration Test (SPT), which are relatively inexpensive and easy to implement.

b. The interpretive technique does not depend on a detailed knowledge of pile properties or of soil-pile stress transfer throughout the length of the pile. 
BIBLIOGRAPHY

BOOKS

Bowles, J.E. (1988), Foundation Analysis and Design, 4th Edition, Mc Graw-Hill, New York. pp. 733-738.

Tomlinson, M.J. (1977), Pile Design and Construction Practice, A Viewpoint Publication, Cement and Concrete Association, London, pp. 9-174.

\section{ARTICLES}

Begemann, H.K.S. (1965), The Maximum Pulling Force on a Single Tension Pile Calculated on the Basis of Results of the Adhesion Jacket Cone, Proceedings of the 6th International Conference on Soil Mechanics and Foundation Engineering, Montreal, Vol. 2, p. 229 .

Brierley, G.S., Thompson, D.E. and Eller, C.W. (1979), Interpreting End-Bearing Pile Load Test Results, Behavior of Deep Foundations, ASTM STP 670, Raymond Lundgren, Ed., American Society for Testing and Materials, pp. 181-198.

Burland, J.B., Butler, F.G. and Dunican, P. (1966), The Behavior and Design of Large Diameter Bored Piles in Stiff Clay, Proceedings of the symposium on Large Bored Piles, Institution of Civil Engineers and Reinforced Concrete Association, London, pp. 51-71.

Cheng, T.Y. (1987), Geotechnical Characteristics of Sungshan Formation within Taipei City, M. Eng. Thesis, Asian Institute of Technology Bangkok.

Coyle, H. M. and Reese L.C. (1966), Load Transfer for Axially Loaded Piles in Clay, Journal of the Soil Mech. and Found. Div. ASCE, Vol. 92, SM2, pp. 1-26.

G. G. Meyerhof (1976), Bearing Capacity and Settlement of Pile Foundations, Journal of the Geotechnical Engineering Division 
(ASCE), 102 (GT3), March 1976, pp. 197-228.

Hirany, A and Kulhawy, F.H. (1989), Interpretation of Load Tests on Drilled Shafts, part 1: Axial Compression, Foundation Engineering; Current Principles and practices, Vol. 2, ASCE, pp. 1132-1149.

Huang, T.C. (1962), The Sungshan Formation in the Taipei Basin, Memoir of the Geological Society of China, No. 1, pp. 133-151, July.

Hung, J.J. (1966), Physical Properties of Quaternary Sediments in Taipei Basin, Bulletin of the college of Engineering, National Taiwan University, No. 1 (in Chinese).

Meigh, A.C. (1987), Cone Penetration Testing: Method and Interpretation, CIRIA Ground Engineering Report: In-situ Testing, pp. 71-72.

Moh, Z. C. and Ou, C. D. (1979), Engineering Characteristics of the Taipei Silt, Proceedings of Sixth Asian Regional Conference on Soil Mech. and Found. Engng., Singapore, Vol. 1, pp. 155-158.

Nottingham, I.C. (1975), Use of Quasi-Static Friction Cone Penetrometer Data To Predict Load Capacity of Displacement Piles, Doctor's Thesis, University of Florida, Gainesville.

O'Neill, M.W. and Reese, L.C. (1972), Behavior of Bored Piles in Beaumont Clay, Journal of the Soil Mechanics and Foundations Division, ASCE Vol. 98, SM2. pp. 195-213.

Tanal, V. (1990). Transit Design in the Variable Eormations of Taipei, Tenth Southeast Asian Geotechnical Conference, Taipei, pp. 575-580.

Robertson, P. K. and Campanella, R. G. (1984), Guidelines for Use and Interpretation of the Electric Cone Penetration Test, Soil Mechanics Series No. 69, Dept. of C. E., The University of British Columbia, Vancouver.

Schmertmann, J.H. (1978), Guidelines for Cone Penetration Test, 
Performance and Design, Federal Highway Administration, Report FHWA-TS-78-209, Washington, July 1978, pp. 127-130.

Skempton, A.W. (1959), Cast in-situ Bored piles in London Clay, Geotechnique, Vol. 9, No. 4-1959, pp. 153-173.

Tumay, M.T. and Fakhroo, M. (1981), Pile Capacity in Soft Clays Using Electric QCPT Data, ASCE, Specialty Conference on Cone Penetration Testing and Experience, october 1981, pp. 434-455.

Vesic, A.S. (:1967), A study of Bearing Capacity of Deep Foundation, Final Rep., Prof. B-189, School of Civil Eng., Georgia Institute of Technology, Atlanta, GA.

Wesley, I.D. (1967), The Dutch Penetrometer and Its Use in Indonesia, Proceedings, southeast Asian Conference of Soil Engineering, Bangkok, pp. 223-230.

Whitaker, T. and Cooke, R. W. (1966), An Investigation of the Shaft and Base Resistance of Large Bored Piles in London Clay, Proceedings of the symposium on Large Bored piles, Institution of Civil Engineers, London, pp. 7-49.

Woo, S.M. and Moh, Z.C. (1990), Geotechnical Characteristics of Soils in the Taipei Basin, Tenth Southeast Asian Geotechnical Conference, Special Taiwan Session. 